\title{
Status of Perennial Tree Germplasm Resources in India and their Utilization in the Context of Global Genome Sequencing Efforts
}

Kunasekaran Rajarajan, Alka Bharati, Hirdayesh Anuragi, Arun Kumar Handa, Kishor Gaikwad, Nagendra Kumar Singh, Kamal Prasad Mohapatra,

Puran Chandra, Sangram Bhanudas Chavan, Lal Chand, Veena Gupta, Ravinder Singh Dhillon, Chhavi Sirohi, Fatima Shirin, Sengodan Saravanan, Kundapura $R$ Ravishankar, Murugan Sankaran, Harsh Mehta, Govindarajan Venkatesh, Archana Verma, Rajwat K Kalia, Modhumita Ghosh Dasgupta, Ramasamy Yasodha, Harish Singh Ginwal, Rupesh Deshmukh, Surendra Kumar Malik, Suryanarayan Bhaskar, Altafhusain Nadaf, Devashree Nayak,

Shiv Kumar Dhyani, Prasad Suresh Hendre, Javed Rizvi 


\section{Status of Perennial Tree Germplasm Resources}

\section{in India and their Utilization in the Context of}

Global Genome Sequencing Efforts

Kunasekaran Rajarajan, Alka Bharati, Hirdayesh Anuragi, Arun Kumar Handa,

Kishor Gaikwad, Nagendra Kumar Singh, Kamal Prasad Mohapatra, Puran Chandra, Sangram Bhanudas Chavan, Lal Chand, Veena Gupta, Ravinder Singh Dhillon, Chhavi Sirohi, Fatima Shirin, Sengodan Saravanan, Kundapura R Ravishankar, Murugan Sankaran, Harsh Mehta, Govindarajan Venkatesh, Archana Verma, Rajwat K Kalia, Modhumita Ghosh Dasgupta, Ramasamy Yasodha, Harish Singh Ginwal, Rupesh Deshmukh, Surendra Kumar Malik, Suryanarayan Bhaskar, Altafhusain Nadaf, Devashree Nayak, Shiv Kumar Dhyani, Prasad Suresh Hendre, Javed Rizvi 
Correct citation: Rajarajan K, Bharati A, Anuragi H, Handa AK, Gaikwad K, Singh NK, Mohapatra KP, Chandra P, Chavan SB, Chand L, Gupta V, Dhillon RS, Sirohi C, Shirin F, Saravanan S, Ravishankar KV, Sankaran M, Mehta H, Venkatesh G, Verma A, Kalia RK, Dasgupta MG, Yasodha R, Ginwal HS, Deshmukh R, Malik SK, Bhaskar S, Nadaf A, Nayak D, Dhyani SK, Hendre PS, Rizvi J. 2020. Status of perennial tree germplasm resources in India and their utilization in the context of global genome sequencing efforts. Working Paper number 311 . World Agroforestry, Nairobi, Kenya. DOI http://dx.doi.org/10.5716/WP2020050.PDF

The titles of the Working Paper Series are intended to disseminate provisional results of agroforestry research and practices and to stimulate feedback from the scientific community. Other World Agroforestry publication series include Technical Manuals, Occasional Papers and the Trees for Change Series.

Published by World Agroforestry

South Asia Regional Programme,

C-Block, 1st Floor, NASC Complex,

Dev Prakash Shastri Marg, Pusa Campus

New Delhi - 110012 | India

T: +91-11-25847885, 25847886

Email: icraf-india@cgiar.org

Website: www.worldagroforestry.org

ICAR-Central Agroforestry Research Institute (CAFRI), Jhansi, Uttar Pradesh 284003, India

Website: www.cafri.res.in

(C) ICRAF \& CAFRI, 2020

Working Paper No. 311 
The views expressed in this publication are those of the contributor(s) and not necessarily those of the World Agroforestry (ICRAF) or ICAR-CAFRI.

Articles appearing in this publication may be quoted or reproduced without charge, provided the source is acknowledged. ICRAF and ICAR-CAFRI encourage fair use of the material in this publication for non-commercial purposes with proper acknowledgment.

The use of trade names in this publication does not imply endorsement of, or discrimination against, any product by ICAR-CAFRI and ICRAF.

The geographic designations used here are not an expression of any opinion whatsoever on the part of ICAR-CAFRI and ICRAF concerning the legal delimitations and boundaries of towns and cities. 


\section{ABOUT THE AUTHORS}

Dr. K. Rajarajan, Alka Bharati, H. Anuragi, Dr. A. K. Handa, S. B. Chavan, Lal Chand are scientists at the ICAR-Central Agroforestry Research Institute (CAFRI), Jhansi, Uttar Pradesh;

Dr. Kishor Gaikwad Principal Scientist and Dr. N. K. Singh, Director at the ICAR-National Institute for Plant Biotechnology (NIPB), New Delhi;

Dr. K. P. Mohapatra Principal Scientist, and Dr. Puran Chandra Scientist at the ICAR - Research Complex for North Eastern Hill Region, Umiam, Meghalaya;

Dr. Veena Gupta Principal Scientist \& Head, Division of Conservation at the National Bureau of Plant Genetic Resources (NBPGR) ICAR, New Delhi;

Dr. R. S. Dhillon and Chhavi Sirohi are scientists at the Chaudhary Charan Singh Haryana Agricultural University, Hisar;

Dr. Fatima Shirin and Dr. S. Saravanan are Principal Scientists at the Tropical Forest Research Institute, ICFRE Jabalpur;

Dr. K.V. Ravishankar and Dr. M. Sankaran are Principal Scientists at ICAR's Indian Institute for Horticulture Research (IIHR), Bengaluru;

Dr. H. Mehta is a Principal Scientist and Head Division of Plant Sciences at ICAR's Indian Institute of Soil \& Water Conservation, Dehradun;

Dr. G. Venkatesh is a scientist at the ICAR's Central Research Institute for Dryland Agriculture, Hyderabad;

Dr. Archana Verma and Dr. Rajwat K. Kalia are scientists at the ICAR's Central Arid Zone Research Institute, Jodhpur;

Dr. S. K. Malik is Principal Scientist at ICAR's Krishi Bhawan, while Dr. S. Bhaskar is an Assistant Director General (Agronomy, Agroforestry and Climate Change) at ICAR's Natural Resource Management Division, Pusa, New Delhi;

Dr. Modhumita Ghosh Dasgupta and Dr. R. Yasodha are scientists at the Institute of Forest Genetics \& Tree Breeding, ICFRE, Coimbatore;

Dr. H. S. Ginwal is a scientist at the Division of Genetics and Tree Improvement, Forest Research Institute Dehradun, ICFRE, Dehradun; 
Dr. Rupesh Deshmukh is a scientist at the National Agri-Food Biotechnology Institute (NABI), Department of Biotechnology, Mohali;

Dr. Altafhusain Nadaf is a Professor in the Department of Botany, Savitribai Phule Pune University, Pune;

Devashree Nayak and Dr. S. K. Dhyani are scientists at the South Asia Regional Programme (SARP), World Agroforestry (ICRAF) based at New Delhi, India, while Dr. Javed Rizvi is the Director of SARP;

Dr. Prasad S. Hendre is a genomics scientist at World Agroforestry (ICRAF) HQ, Nairobi, Kenya.

\section{Corresponding contributors}

Dr. A. K. Handa, Central Agroforestry Research Institute (CAFRI) ICAR, Jhansi email: arun.handa@icar.gov.in;

Dr. S. K. Dhyani, World Agroforestry, ICRAF, New Delhi email: s.dhyani@cgiar.org

\section{The Organizations}

The Central Agroforestry Research Institute (CAFRI) is a national institute and India's only dedicated research institution on agroforestry under the umbrella of the Indian Council of Agricultural Research (ICAR). It promotes and works on improving the quality of life of rural people through integration of perennials in agricultural landscapes for economic, environmental and social benefits.

The Indian Council of Agricultural Research (ICAR) is the research wing of the Ministry of Agriculture \& Farmers Welfare, Government of India. It harnesses the power of science and innovation for food security, food safety and farmer's prosperity, as well as enhances the natural resource base to promote inclusive growth and sustainable development.

World Agroforestry (ICRAF) is a centre of scientific excellence that harnesses the benefits of trees for people and the environment. Leveraging the world's largest repository of agroforestry science and information, ICRAF develops knowledge practices, from farmers' fields to the global 
sphere, to ensure food security and environmental sustainability. ICRAF is the only institution that does globally significant agroforestry research in and for all of the developing tropics. The knowledge produced by ICRAF enables governments, development agencies and farmers to utilize the power of trees to make farming and livelihoods more environmentally, socially and economically sustainable at scale.

ICRAF is a member of the CGIAR Consortium. Its headquarters are based in Nairobi, Kenya, with six regional and sub-regional offices located across Africa, Asia, and Latin America.

The Consortium of International Agricultural Research Centres (CGIAR) integrates and coordinates the research of its 15 Member Centres to increase the effectiveness and relevance of their work, and to enhance the impact of research by setting common objectives and planning concerted action. 


\section{TABLE OF CONTENTS}

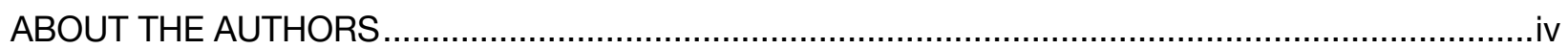

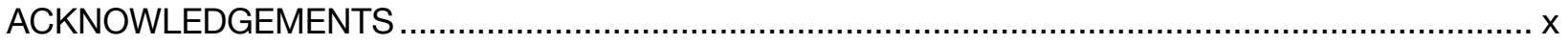

LIST OF ABBREVIATIONS AND ACRONYMS .............................................................................

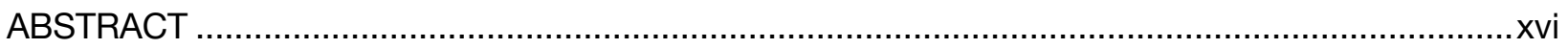

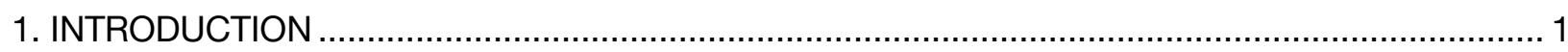

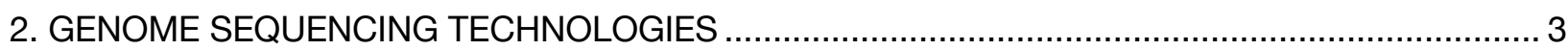

2.1. Capillary-based first-generation sequencing technologies ............................................ 3

2.2. Second-generation sequencing (SGS) technologies .................................................... 3

2.3. Third-generation sequencing (TGS) technologies .................................................... 4

2.4. Chromatin conformation capture and sequencing ................................................... 5

3. GLOBAL STATUS OF GENOME SEQUENCING OF WOODY PERENNIAL AND TREE SPECIES.. 5

4. APPLICATION OF GENOMIC-BASED TECHNOLOGIES FOR PERENNIAL WOODY AND TREE

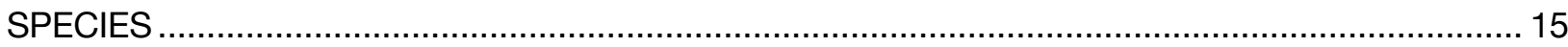

5. CURRENT SCENARIO OF TREE GENOMICS RESEARCH GLOBALLY .................................. 16

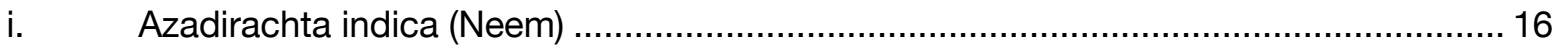

ii. Dalbergia sissoo (North Indian rosewood) …................................................ 18

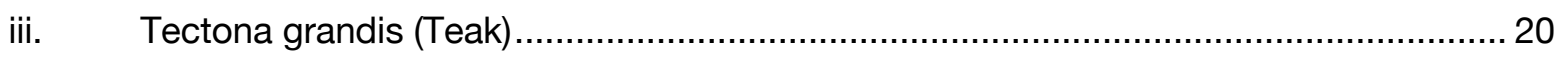

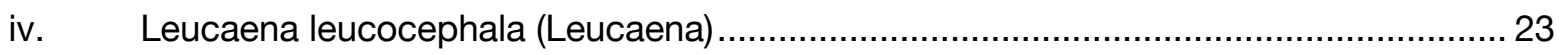

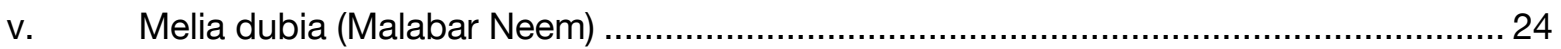

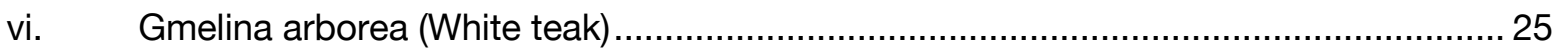

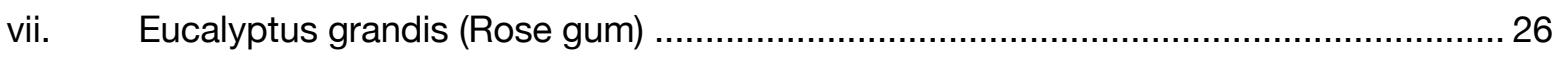

viii. Isolation and characterization of cell wall related genes in Eucalyptus tereticornis ..... 28

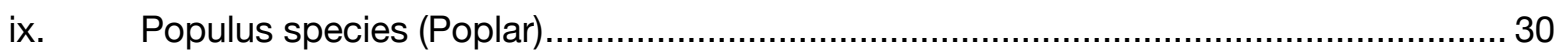

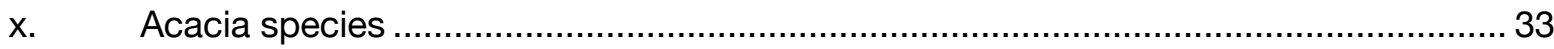

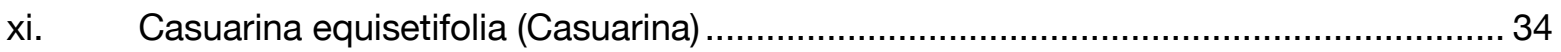

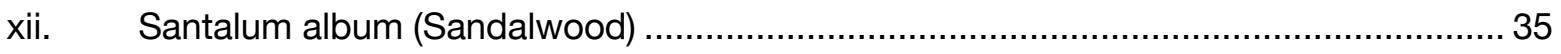




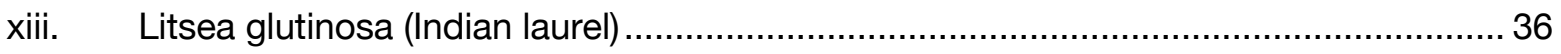

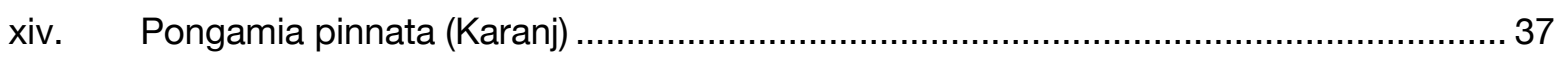

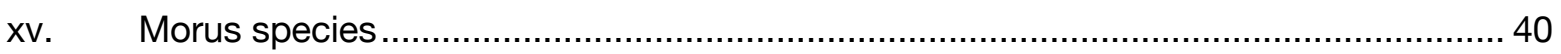

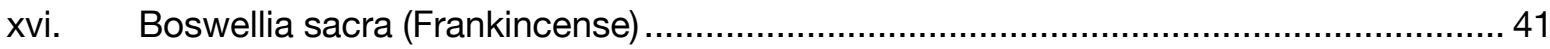

xvii. Moringa oleifera (Drumstick) ................................................................................. 41

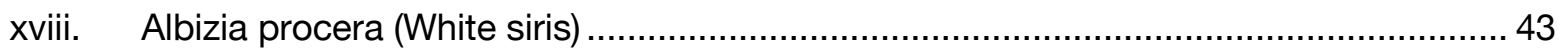

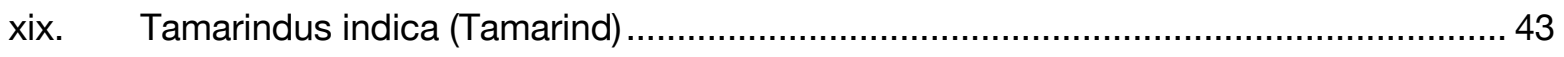

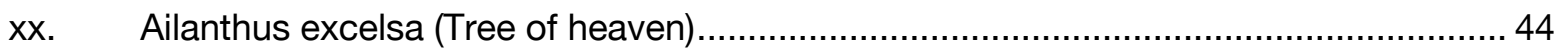

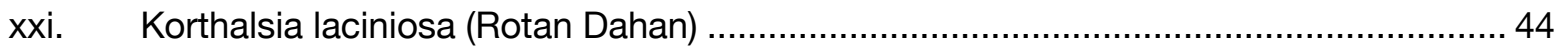

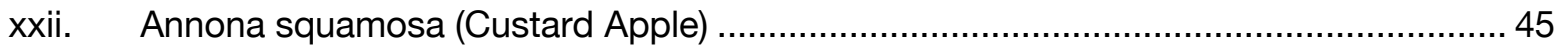

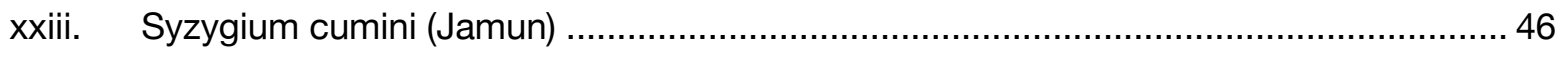

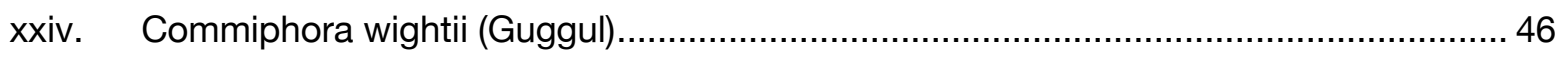

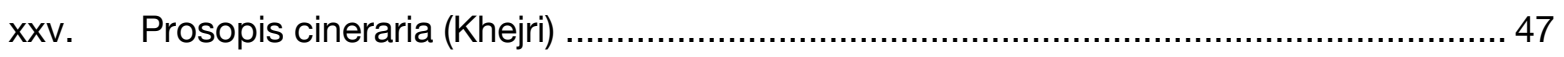

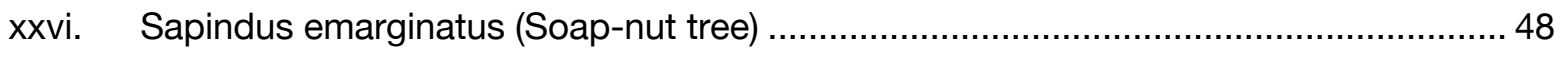

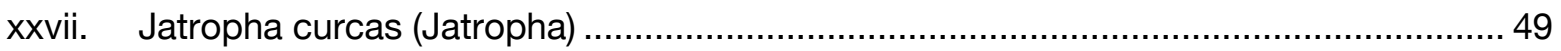

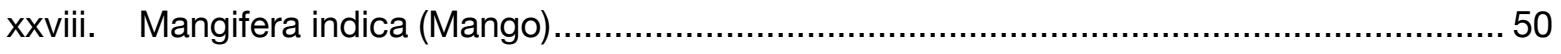

xxix. Quercus leucotrichophora (Banj oak) ..................................................... 51

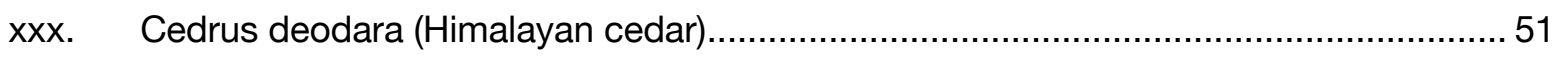

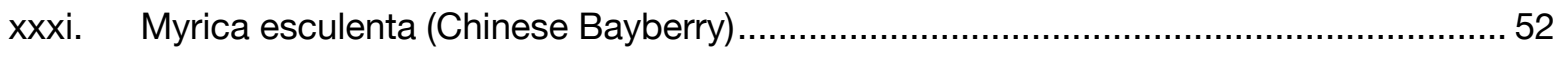

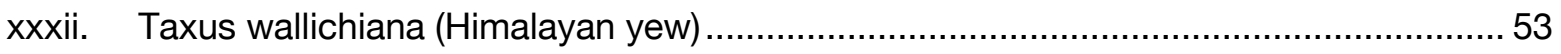

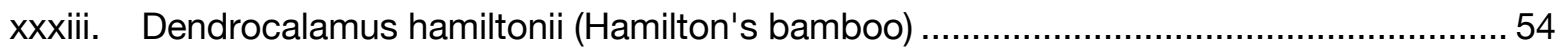

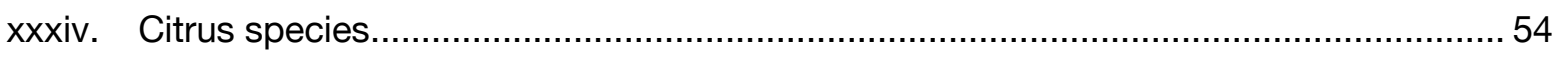

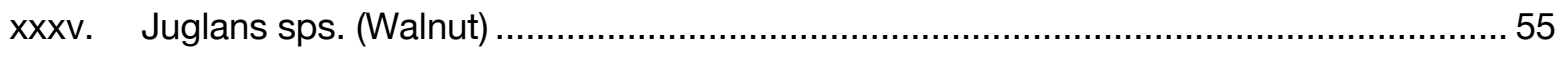

6. INTERNATIONAL EFFORTS TOWARDS GENERATING GENOMICS RESOURCES FOR

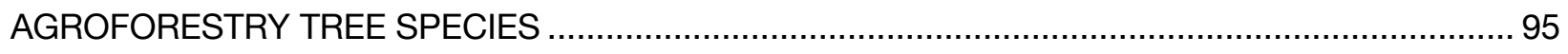

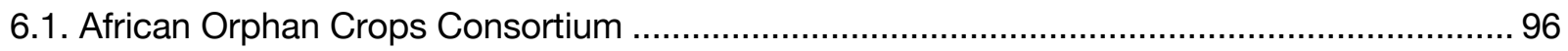

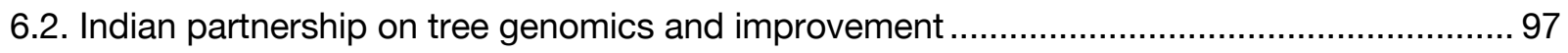




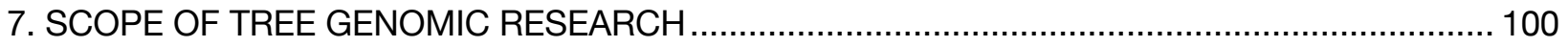

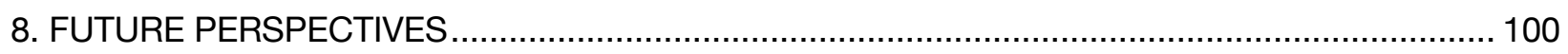

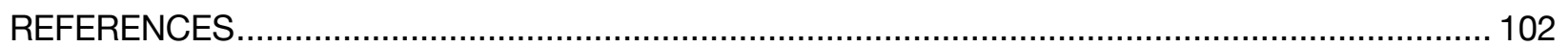




\section{ACKNOWLEDGEMENTS}

We thankfully acknowledge the following individuals and organizations for their valuable support and contributions to this publication:

Dr T Mohapatra, Secretary, DARE \& Director General, ICAR; Dr S K Chaudhari, Deputy Director General (NRM), ICAR; Dr A Arunachalam Assistant Director General (IR), ICAR; Dr R K Tewari, Director, ICAR-Central Agroforestry Research Institute (CAFRI), Jhansi \& Project Coordinator, AICRP on Agroforestry; Dr K Singh, Director, ICAR-National Bureau of Plant Genetic Resources (NBPGR), New Delhi; Dr M R Dinesh, Director, ICAR-Indian Institute for Horticulture Research (IIHR), Bengaluru; Dr O P Yadav, Director, ICAR-Central Arid Zone Research Institute, Jodhpur; Dr G R Chari, Director, ICAR-Central Research Institute for Dryland Agriculture, Hyderabad; Dr B Kandpal, Director, ICAR Research Complex for North Eastern Hill (RC NEH) Region, Umiam, Meghalaya; Dr P R Ojaswi, Director, Indian Institute of Soil \& Water Conservation, Dehradun.

Dr T R Sharma, Executive Director, National Agri-Food Biotechnology Institute (NABI), Department of Biotechnology, Government of India. Dr S K Sehrawat, Director Research, Chaudhary Charan Singh Haryana Agricultural University, Hisar.

Dr S C Gairola, Director General, Indian Council of Forestry Research and Education (ICFRE), Dehradun; Dr V Kothiyal, Assistant Director General (Research Planning), ICFRE, Dehradun; Dr S Senthilkumar, Director and Dr S Murugesan, Ex-Director, ICFRE-Institute of Forest Genetics \& Tree Breeding, Coimbatore; Dr G Rajeshwar Rao, Director, ICFRE-Tropical Forest Research Institute, Jabalpur.

Dr T Simons, Director General for overall support; and Dr R Prabhu, Deputy Director General (Research), Dr R Jamnadass, and Dr G Lars, all from ICRAF, Nairobi for reviewing the manuscript and providing valuable inputs.

Financial support received from ICAR through the ICAR-CGIAR programme is gratefully acknowledged. 


\section{LIST OF ABBREVIATIONS AND ACRONYMS}

ACC

AF

AFLP

AGL

AICRPAF

AMOVA

AOCC

AREB

ARF

ARM

BAC

BGI

BI

CAFRI

CAP

CC

cDNA

CeSA

CGIAR

Chi1

CIMAP

$\mathrm{Cp}$

cpDNA

cpSSR

CPT

CRIDA

CRISPR

CSIR

CSO

DAMD

DArT

DBBT
Accession

Agroforestry

Amplified fragment length polymorphism

Agamous-Like

All India Coordinated Research Project on Agroforestry

Analysis of Molecular Variance

African Orphan Crops Consortium

Abscisic acid Responsive Element-Binding protein

Auxine Responsive Factor

Armadillo

Bacterial Artificial Chromosome

Beijing Genomics Institute

Bax Inhibitor

Central Agroforestry Research Institute

Citrus Annotation Project

Coiled coil

Complementary DNA

Cellulose synthase

Consortium of International Agricultural Research Centres

Chitinase1

Central Institute of Medicinal and Aromatic Plants

Chloroplast

Chloroplast DNA

Chloroplast Simple Sequence Repeats

Candidate Plus Trees

Central Research Institute for Dryland Agriculture

Clustered Regularly Interspaced Short Palindromic Repeats

Council for Scientific and Industrial Research

Clonal Seed Orchard

Directed Amplification of Minisatellite DNA

Diversity Arrays Technology

2-Debenzoyl-7,13-diacetylbaccatin III-2-O-benzoyl transferase 


$\begin{array}{ll}\text { DEGs } & \text { Differentially expressed genes } \\ \text { DEmiRs } & \text { Differentially Expressed miRNAs } \\ \text { DNA } & \text { Deoxyribonucleic Acid } \\ \text { DPPH } & \text { 1,1-diphenyl-2-picrylhydrazyl } \\ \text { DREB } & \text { Dehydration Responsive Element-Binding protein } \\ \text { DUS } & \text { Distinctness Uniformity and stability } \\ \text { EMA } & \text { Enzymatic Maceration and Air Drying } \\ \text { EMS } & \text { Ethyl Methane Sulphonate } \\ \text { ERF } & \text { Ethylene Responsive Factors } \\ \text { ESTs } & \text { Expressed Sequence Tag } \\ \text { EYE } & \text { Embryo Yellow } \\ \text { F5H } & \text { Ferulate 5-Hydroxylase } \\ \text { FAO } & \text { Food and Agriculture Organization of the United Nations } \\ \text { FISSR } & \text { Fluorescent-ISSR } \\ \text { FMCG } & \text { Fast-Moving Consumer Goods } \\ \text { FRAP } & \text { Ferric Reducing Antioxidant Power } \\ \text { FRI } & \text { Forest Research Institute } \\ \text { FT } & \text { Flowering locus T } \\ \text { GABA } & \text { Gamma Amino Butyric Acid } \\ \text { Gb } & \text { Giga bases } \\ \text { GBS } & \text { Genotyping-by-sequencing } \\ \text { GC } & \text { Guanine-Cytosine } \\ \text { GC-MS-FID } & \text { Gas Chromatography-Mass Spectrometry- Flame lonization Detection } \\ \text { Gl } & \text { Gigantea } \\ \text { GLP } & \text { Germin Like Protein } \\ \text { GO } & \text { Gene Ontology } \\ \text { GRAS } & \text { Gibberellic Acid Insensitive (GAl), Repressor of GA1 (RGA), and Scarecrow (SCR) } \\ \text { GS } & \text { Genome Sequence } \\ \text { GS } & \text { Genomic Selection } \\ \text { GWAS } & \text { Genome Wide Association Studies } \\ \text { HB2 } & \text { Hemoglobin 2 } \\ \text { He } & \text { Expected Heterozygosity Mean } \\ \text { HiC } & \text { Hypermethylated in Cancer } \\ & \end{array}$




$\begin{array}{ll}\text { Ho } & \text { Observed Heterozygosity Mean } \\ \text { HSP } & \text { Heat Shock Protein } \\ \text { HS-SPME } & \text { Headspace Solid-Phase Microextraction } \\ \text { HT } & \text { Total heterozygosity } \\ \text { HUL } & \text { Hindustan Unilever Limited } \\ \text { IARI } & \text { Indian Agricultural Research Institute } \\ \text { ICAR } & \text { Indian Council of Agricultural Research } \\ \text { ICFRE } & \text { Indian Council of Forestry Research and Education } \\ \text { ICGC } & \text { International Citrus Genome Consortium } \\ \text { ICRAF } & \text { World Agroforestry } \\ \text { IFGTB } & \text { Institute of Forest Genetics and Tree Breeding } \\ \text { IIHR } & \text { Indian Institute of Horticultural Research } \\ \text { InDels } & \text { Insertion Deletions } \\ \text { IR } & \text { Inverted Repeat region } \\ \text { ISSH } & \text { Interspecies Suppression Subtractive Hybridization } \\ \text { ISSR } & \text { Inter Simple Sequence Repeat } \\ \text { ITS } & \text { Internal Transcribed Spacer } \\ \text { JMV } & \text { Jatropha Mosaic Virus } \\ \text { KASP } & \text { Kompetitive Allele Specific PCR } \\ \text { Kb } & \text { Kilo base } \\ \text { LEA } & \text { Late Embryogenesis Abundant } \\ \text { LSC } & \text { Large Single-Copy region } \\ \text { MAPKs } & \text { Microtubule Associated Protein Kinase } \\ \text { MCSU } & \text { Molybdenum Cofactor Sulfurase } \\ \text { miRNA } & \text { micro RNA } \\ \text { MNC } & \text { Multinational Company } \\ \text { MPTS } & \text { Multi-Purpose Tree Species } \\ \text { MSL } & \text { Mean Sea Level } \\ \text { mtDNA } & \text { Mitochondrial DNA } \\ \text { MYB } & \text { Myeloblastosis } \\ \text { NABI } & \text { National Agri-Food Biotechnology Institute } \\ \text { NBPGR } & \text { National Bureau of Plant Genetic Resources } \\ \text { NCBI } & \text { National Centre for Biotechnology Information } \\ & \end{array}$




\begin{tabular}{|c|c|}
\hline NCU & Neem Coated Urea \\
\hline NEB & N-Ethylbuphedrone \\
\hline NGO & Non-Governmental Organization \\
\hline NGS & Next Generation Sequencing \\
\hline NRM & Natural Resource Management \\
\hline nSSR & Nuclear Simple Sequence Repeats \\
\hline ONT & Oxford NanoPore Technologies \\
\hline OP & Open Pollinated \\
\hline PAM & Protospacer Adjacent Motif \\
\hline PCA & Principle Component Analysis \\
\hline PCR & Polymerase Chain Reaction \\
\hline PEG & Polyethylene Glycol \\
\hline PIC & Polymorphic Information Content \\
\hline PIP & Plasma membrane Intrinsic Protein \\
\hline PISSR & Pongamia Inter-Simple Sequence Repeats \\
\hline PR & Pathogenesis-Related \\
\hline q-PCR & Quantitative-Polymerase Chain Reaction \\
\hline qRT-PCR & Quantitative Reverse Transcriptase PCR \\
\hline QTL & Quantitative Trait Loci \\
\hline RAD & Restriction site Associated DNA \\
\hline RAPD & Random Amplification of Polymorphic DNA \\
\hline RNA & Ribonucleic Acid \\
\hline rRNA & ribosomal RNA \\
\hline SAU & State Agricultural Universities \\
\hline SBS & Sequencing by Synthesis \\
\hline SCAR & Sequence Characterized Amplified Regions \\
\hline SDS & Sodium Dodecyl Sulfate \\
\hline SGS & Second Generation Sequencing \\
\hline SMRT & Single Molecule Real-Time \\
\hline SND & Secondary Wall-Associated NAC Domain \\
\hline SNP & Single Nucleotide Polymorphism \\
\hline SNVs & Single Nucleotide Variants \\
\hline SPME & Solid-Phase Micro-Extraction \\
\hline
\end{tabular}




$\begin{array}{ll}\text { SRAP } & \text { Sequence-Related Amplified Polymorphism } \\ \text { SRS } & \text { Short Read Sequencing } \\ \text { SSC } & \text { Small Single-Copy region } \\ \text { SSR } & \text { Simple Sequence Repeat } \\ \text { StLFR } & \text { Single tube Long Fragment Read } \\ \text { TAT } & \text { Taxadienol acetyltransferase } \\ \text { TGS } & \text { Third Generation Sequencing } \\ \text { TNPL } & \text { Tamilnadu Newsprint \& Papers Limited } \\ \text { TPS } & \text { Tandem Duplicated Terpene Synthase } \\ \text { tRNA } & \text { Transfer RNA } \\ \text { UHS } & \text { University of Horticulture Science } \\ \text { USA } & \text { United States of America } \\ \text { VND } & \text { Vascular-Related NAC-Domain } \\ \text { WIP } & \text { Walnut Improvement Program }\end{array}$




\section{ABSTRACT}

Tree species are characterized by their perennial growth habit, woody morphology, long juvenile period phase, mostly outcrossing behaviour, highly heterozygosity genetic makeup, and relatively high genetic diversity. The economically important trees have been an integral part of the human life system due to their provision of timber, fruit, fodder, and medicinal and/or health benefits. Despite its widespread application in agriculture, industrial and medicinal values, the molecular aspects of key economic traits of many tree species remain largely unexplored. Over the past two decades, research on forest tree genomics has generally lagged behind that of other agronomic crops. Genomic research on trees is motivated by the need to support genetic improvement programmes mostly for food trees and timber, and develop diagnostic tools to assist in recommendation for optimum conservation, restoration and management of natural populations. Research on long-lived woody perennials is extending our molecular knowledge and understanding of complex life histories and adaptations to the environment, enriching a field that has traditionally drawn its biological inference from a few short-lived herbaceous species. These concerns have fostered research aimed at deciphering the genomic basis of complex traits that are related to the adaptive value of trees. This review summarizes the highlights of tree genomics and offers some priorities for accelerating progress in the next decade. We begin by introducing some of the key agroforestry (AF) tree species used in genomic research by various institutions/organizations. The publication then briefly reviews the progress in genomics and other related areas in selected species like Populus deltoides (poplar), Eucalyptus tereticornis (eucalyptus), Tectona grandis (teak), Bamboo species (bamboo), Dalbergia sissoo (sissoo), Azadirachta indica (neem), Casuarina equisetifolia (casuarina), Leucaena leucocephala (Leucaena), Acacia nilotica (Indian babool), Prosopis cineraria (khejri), Tamarindus indica (tamarind), Syzygium cumini (jamun), Citrus species (citrus), Moringa oleifera (drumstick) and Mangifera indica (mango). Germplasm of these species is maintained in the form of seeds as in-situ field genebank collections and also as ex-situ seed collections under appropriate conditions largely by various affiliate institutes of the Indian Council of Agricultural Research (ICAR), headquartered in New Delhi, India; Indian 
Council of Forestry Research and Education (ICFRE), located in Dehradun, India and various state agricultural universities (SAUs) spread all over India. We describe how the basic genomic-based research has been applied for tree breeding with these available resources. Finally, we conclude by highlighting the potential future direction and expected outcomes of genomic research in these tree species which will provide the necessary tools to elucidate the past evolutionary success history and to understand their future response to environmental changes, thus hastening the deployment of breeding populations that can satisfy major economic and livelihood needs.

\section{Keywords}

Agroforestry species, genetic improvement, genome sequencing, national genebank, tree biotechnology, tree genomes, woody perennials 


\section{INTRODUCTION}

Trees are the source of many human needs such as food, fodder, building materials, pulp and paper products, firewood for heating and cooking, medicines and pharmaceutical compounds, and more recently, as a non-conventional renewable bioenergy source. Trees also provide various ecological services such as biodiversity conservation, acting as carbon sinks, climate change adaptation and mitigation, and maintaining water quality. Thus, these trees with diverse functional uses have formed an indispensable part of human life and livelihood from time immemorial. The system where such trees are grown along with field crops on agricultural landscapes is referred to as agroforestry. More precisely, agroforestry is a collective term used to describe land-use systems and technologies where woody perennials (trees, shrubs, palms, bamboos, etc.) are deliberately integrated into the same land-management units with crops and/or animals, in some form of spatial arrangement or temporal sequence. India has a very long historical tradition of agroforestry with important tree species such as Populus deltoides (poplar), Eucalyptus tereticornis (eucalyptus), Tectona grandis (teak), Bamboo species (bamboo), Dalbergia sissoo (sissoo), Azadirachta indica (neem), Casuarina equisetifolia (casuarina), Leucaena leucocephala (Leucaena), Acacia nilotica (Indian babool), Prosopis cineraria (khejri) etc. All these have multiple uses. Besides, horticultural tree species such as Tamarindus indica (tamarind), Syzygium cumini (jamun), Citrus species (citrus), Moringa oleifera (drumstick) and Mangifera indica (mango) are used as fruits, vegetables and/or spices and condiments. Lately, they have been referred to as 'food trees'. Species such as poplar, eucalyptus, melia, casuarina and leucaena ( $L$. leucocephala) are the major industrial species mainly used in the timber, paper and pulp industry.

Tree improvement has generally been lagging in comparison to annual field crops due to inherent biological limitations such as very long seed-to-seed generation cycle, slow growth and delayed economic returns, high heterozygosity, high inbreeding depression and under-studied floral and reproductive biology. Genomics and genomics-assisted 
crop improvement and selection are promising tools which offer a great opportunity to tackle some of these issues. They could result in expediting genetic gains, high returns on investment, faster upscaling and turn-around time for varietal development, and also enhance understanding of basic biology of economic and reproductive traits. Besides, tree genomics research supports genetic improvement programmes and develops diagnostic tools, thus enabling development of recommendations for optimum conservation, restoration and management of natural populations. Research progress on trees is very limited due to genome complexity, lack of reverse genetic approaches and more importantly, lack of investment in research and development activities. The scope of genomic research in trees primarily aims to:

i. Understand the structure and evolution of various trees and their genomes

ii. Discover biology, genes and pathways behind phenotypes, economic traits and understand the genotype-phenotype interactions using genomic tools

iii. Translate discovered genomics knowledge into developing genomic-based tools for genetic enhancement of forest trees with special reference to the changing climate scenario

iv. Develop landscape genomic approaches to understand population structures of tree species for recommendation in conservation and restoration strategies

v. Develop diagnostic tools for assessment of tree and forest health and understand epidemiology of tree diseases

These objectives can be accomplished by the genome sequencing of trees and finding genomic diversity present in different populations of these trees. They can further help in comprehensive understanding of the structure of tree genomes in the context of evolution. In addition, the inter-relation of gene functions and the phenotypes, with an emphasis on longevity, perennial and woody habit, and phenotypic plasticity in domesticated and natural populations will help to manage forest tree populations in the face of a changing climate scenario and other challenges (degradation and loss due to disease, fires, unstructured felling, etc.). 


\section{GENOME SEQUENCING TECHNOLOGIES}

\subsection{Capillary-based first-generation sequencing technologies}

Genome sequencing based on Sanger sequencing approach performed in individual capillaries was the only possible option for around three decades (1975-2000) (Shendure et al 2017). The sequencing space was primarily dominated by Applied Biosystems Inc. through its different instrumentation platforms such as ABI Prism 377, ABI Prism 3100, ABI Prism 3700, ABI Prism 3730 and to a lesser extent, by Amersham's Megabace 1000. Both of these could sequence DNA to a length of up to $700-900$ bases in a single reaction. Due to technological limitations, the output was very low and expensive, but it provided a reasonably good sequence quality to undertake initial plant genome sequencing projects for Arabidopsis (Arabidopsis Genome Initiative 2000) and rice (Sasaki 2005).

The traditional Sanger sequencing approach could sequence up to 96 samples in tandem in a single or multiple capillary setting at a time, restricting upscaling and data generation capabilities. The advancements in robotics, mechanics, nanotechnology, optical physics and computational capacity enabled the development of the next level of instrumentation that followed, which was capable of sequencing billions of DNA fragments in parallel at the same time. Thus, these massively parallel sequencing technologies are referred to as high throughput sequencing technologies. All these new and innovative sequencing approaches, which used these developments were sequentially referred to as second- or third-generation sequencing technologies (Karger and Guttman 2009; Durney et al 2015).

\subsection{Second-generation sequencing (SGS) technologies}

The SGS technologies were able to conduct tens of millions of microscale sequencing reactions in parallel on a small glass slide or similar equipment using the traditional Sanger sequencing approach, thereby producing data at a scale that was unprecedented. Although it revolutionized the genome sequencing space, the SGS 
technologies had a major drawback of sequencing length, where only up to a maximum of 600 bases (on MiSeq platform) could be sequenced in a single reaction. However, in most cases, the sequencing length was restricted to 250 bases (for other HiSeq platforms). These included technologies by companies such as Illumina (Sequencing by synthesis - SBS approach through their GAllx, MiSeq, NextSeq, HiSeq 2000, HiSeq 2500, HiSeq 4000, HiSeq X Five, HiSeq X Ten, NovaSeq 6000 platforms) and Thermo Fisher Scientific which was earlier used by various companies like Roche, and then Life Technologies (Sequencing by Oligonucleotide Ligation and Detection- SOLiD or 454pyrosequencing approach through their platforms like GS-FLX, IonTorrent, IonProton, S5, etc.). However, all these technologies could sequence only a few hundred bases at a time due to limitations on sequencing chemistry and optics at that scale (Reuter et al 2015; Levy and Myers 2016; Heather and Chain 2016).

The plant genomics era where basic genomics-assisted breeding tools were developed for genome-wide association mapping (GWAS) and genomic selection (GS) used these SGS technologies (Bhat et al 2016). The SGS technologies contributed significantly to discovering the most fundamental and important variations present in the genomes, i.e., single nucleotide polymorphisms (SNPs) (Koboldt et al 2013). This resulted in breakthroughs in the advancement of plant breeding and crop improvement toolkits for important field crops.

\subsection{Third-generation sequencing (TGS) technologies}

The limitations of sequencing length of a DNA fragment were improved upon by the thirdgeneration sequencing (TGS) technologies, which can sequence a few Kbs of individual strands of DNA at a very high speed by reading the original DNA molecule; thus, they were also known as single molecule real-time (SMRT) sequencing technologies. These were developed by sequencing companies like Pacific Biosciences, known as PacBio (instrument platforms: RS, RS II, Sequel, Sequel II) (Eid et al 2009), Oxford NanoPore Technologies also referred to as ONT (instrument platforms: MinION, GridION, PromethION) (Clarke et al 2009; Eisenstein 2012), and BioNano Genomics. Apart from 
these actual long-read sequencing technologies, there are synthetic long-read technologies by 10X Genomics and BGI (StLFR) (Ott et al 2018; Peters et al 2014; Wang et al 2019), which use an innovative method where long reads are generated from short reads using barcoded pools of long DNA molecules. Besides, at least two more companies are developing new approaches of TGS, Quantapore, and Stratos Genomics for which information is not yet available. The length of DNA that can be sequenced using TGS technologies is limited only by the length and quality of DNA used to prepare the sequencing library. One of the main downsides of these technologies is that they have higher error rates compared to the earlier SGS technologies. However, it opens up the possibilities for understanding genome reorganizations, structural variations and chromosomal rearrangements apart from SNP variations. Along with SGS technologies, they provide a good option to develop long and reliable genome assemblies and scaffolds (Dijk et al 2018).

\subsection{Chromatin conformation capture and sequencing}

Isolation of DNA in its native chromatin form can help to build chromosome length scaffolds from the sequencing assemblies. Also referred to as $\mathrm{HiC}$, it crosslinks DNAprotein complexes with formaldehyde, followed by DNA fragmentation, ligation, digestion, and then sequencing. This builds chromosome level sequencing scaffolds, which could otherwise be almost impossible. These different sequencing technologies have been widely reported by Levy and Myers (2016); Leggett and Clark (2017); Nakano et al (2017); and Pal et al (2019).

\section{GLOBAL StATUS OF GENOME SEQUENCING OF WOODY PERENNIAL AND TREE SPECIES}

Arabidopsis thaliana was the first plant genome to be sequenced in the year 2000 (Arabidopsis Genome Initiative 2000) using the Sanger shotgun sequencing approach. It took nearly five more years before the second plant genome, rice, (Eckardt, 2000; Sasaki 2005) could be published using a similar approach through an international consortium. It was the year 2006 that the genome sequence for poplar (Tuscan et al 2006), a fast- 
growing model tree species also used for timber, was published using a similar shotgun sequencing approach. The tree genome sequencing scenario was dominated by a similar shotgun approach where DNA fragments were cloned into vectors like plasmids, cosmids, bacterial artificial chromosomes (BACs), etc. and further sequenced via capillary sequencers using the Sanger sequencing approach. Then a real jump in genome sequencing efforts happened only after 2013, where the SGS approach became affordable and available on a large scale.

At the time of writing this review, 45 perennial woody tree species had been sequenced and published (10 timber and wood species, 23 fruit and 12 multipurpose species). Table 1 provides information along with a brief description about the sequencing technology employed by each study. It can be observed that most of the studies have used short read sequencing (SRS) technology, primarily the Illumina-based sequencing platforms, whereas the most recent genomes have used long read SMRT as well as chromatinbased sequencing technology to attain a high quality, chromosome-level genome assemblies. There are 15 studies which have used PacBio SMRT technology, but only five have used the HiC approach to build chromosome-level assemblies (Rubus occidentalis (Black raspberry) - VanBuren et al 2018; Mangifera indica (Mango) - Wang et al 2020; Diospyros oleifera (Persimmon) - Zhu et al 2019a; Actinidia chinensis (Golden kiwifruit) - Wu et al 2019; Hevea brasiliensis (rubber) - Liu et al 2020).

Table 1 presents a list of 45 perennial woody species with diverse functional uses for which genome sequences are publicly available. It provides a short description of different next-generation sequencing (NGS) technologies used for sequencing different tree genomes. 
Table 1. A list of perennial woody species with diverse functional uses for which genome sequences are available in the public domain

\begin{tabular}{|c|c|c|}
\hline SI. No. & Name of species, reference & Sequencing Approach \\
\hline 1 & $\begin{array}{l}\text { Populus trichocarpa (Black } \\
\text { cottonwood tree) Tuskan et al } \\
(2006)\end{array}$ & $\begin{array}{l}\text { Whole genome shotgun strategy based } \\
\text { on random plasmid cloning and } \\
\text { sequencing using the first-generation } \\
\text { Sanger sequencing technology on } A B I \\
\text { PRISM } 3700 \text { DNA Analyzer. The shot gun } \\
\text { genome assembly was aligned using BAC } \\
\text { end sequencing. }\end{array}$ \\
\hline 2 & $\begin{array}{l}\text { Picea abies (Norway Spruce) } \\
\text { Nystedt et al (2013) }\end{array}$ & $\begin{array}{l}\text { Multiple paired end, mate pair and fosmid } \\
\text { DiTag libraries of different sizes } \\
\text { sequenced using Illumina's GAll, HiSeq } \\
2000 \text { and MiSeq. }\end{array}$ \\
\hline 3 & $\begin{array}{l}\text { Picea glauca (White Spruce), } \\
\text { Birol et al (2013) }\end{array}$ & $\begin{array}{l}\text { Multiple paired end, mate pair and fosmid } \\
\text { DiTag libraries of different sizes } \\
\text { sequenced using Illumina's GAll, HiSeq } \\
2000 \text { and MiSeq. }\end{array}$ \\
\hline 4 & $\begin{array}{l}\text { Pinus taeda (Loblolly pine) } \\
\text { a. Neale et al (2014) } \\
\text { b. Zimin et al (2014) }\end{array}$ & $\begin{array}{l}\text { a. Multiple paired end, mate pair and } \\
\text { fosmid DiTag libraries of different sizes } \\
\text { sequenced using Illumina's GA II, HiSeq } \\
2000 \text { and MiSeq. } \\
\text { b. Multiple paired end, mate pair and } \\
\text { fosmid DiTag libraries of different sizes } \\
\text { sequenced using Illumina's GA II, HiSeq } \\
2000 \text { and MiSeq. }\end{array}$ \\
\hline 5 & $\begin{array}{l}\text { Eucalyptus grandis (Rose } \\
\text { gum) Myburg et al (2014) }\end{array}$ & $\begin{array}{l}\text { Multiple BAC, plasmid and fosmid } \\
\text { libraries of different sizes sequenced } \\
\text { using first-generation Sanger sequencing }\end{array}$ \\
\hline
\end{tabular}




\begin{tabular}{|c|c|c|}
\hline & & $\begin{array}{l}\text { and use of linkage maps for chromosome } \\
\text { level assembly. }\end{array}$ \\
\hline 6 & $\begin{array}{l}\text { Betula pendula (Silver birch), } \\
\text { Salojärvi et al (2017) }\end{array}$ & $\begin{array}{l}\text { Multiple paired end small-insert libraries } \\
\text { sequenced using HiScan SQ, MiSeq and } \\
\text { NextSeq } 500 \text {. In addition, mate pair } \\
\text { sequncing for mid-sized libraries done } \\
\text { using SOLiD 5500xl Sequencer, and long } \\
\text { reads generated using PacBio RSII } \\
\text { sequencer. }\end{array}$ \\
\hline 7 & $\begin{array}{l}\text { Quercus robur (English oak), } \\
\text { Plomion et al (2018) }\end{array}$ & $\begin{array}{l}\text { Multiple paired end small-insert libraries } \\
\text { sequenced using HiSeq } 2000 \text { sequencer. }\end{array}$ \\
\hline 8 & $\begin{array}{l}\text { Tectona grandis (Teak), } \\
\text { Yasodha et al. (2018) }\end{array}$ & $\begin{array}{l}\text { A combination of short read sequencing } \\
\text { using HiSeq } 4000 \text { of small, medium and } \\
\text { long insert paired end libraries and long } \\
\text { read sequencing using Oxford } \\
\text { NanoPore's MinION sequencer. }\end{array}$ \\
\hline 9 & $\begin{array}{l}\text { Casuarina equisetifolia } \\
\text { (Beefwood tree), Ye et al } \\
(2019)\end{array}$ & $\begin{array}{l}\text { Multiple paired end small to large insert } \\
\text { libraries sequenced using HiSeq } 2000 \\
\text { sequencer in combination with PacBio } \\
\text { SMRT. }\end{array}$ \\
\hline 10 & $\begin{array}{l}\text { Castanea mollissima (Chinese } \\
\text { chestnut), Xing et al (2019) }\end{array}$ & $\begin{array}{l}\text { Small insert paired end libraries were } \\
\text { sequenced using HiSeq } 2500 \text { and long } \\
\text { read sequencing using PacBio SMRT } \\
\text { technology. }\end{array}$ \\
\hline 11 & $\begin{array}{l}\text { Vitis vinifera (Grapevine), } \\
\text { Jaillon et al (2007) }\end{array}$ & $\begin{array}{l}\text { Whole genome shot gun sequencing } \\
\text { using } A B|3730 x| \text { and assembly using } B A C \\
\text { end sequencing }\end{array}$ \\
\hline
\end{tabular}




\begin{tabular}{|c|c|c|}
\hline 12 & $\begin{array}{l}\text { Carica papaya (Papaya), Ming } \\
\text { et al (2008) }\end{array}$ & $\begin{array}{l}\text { Whole genome shotgun sequencing of } \\
\text { plasmids and BAC end sequencing using } \\
\text { capillary sequencer. }\end{array}$ \\
\hline 13 & $\begin{array}{l}\text { Malus domestica } \\
\text { Velasco et al (2010) }\end{array}$ & $\begin{array}{l}\text { Small to large sized shot gun libraries in } \\
\text { plasmids sequenced using Sanger } \\
\text { sequencing on ABI } 3730 X L \text { DNA Analyzer } \\
\text { and mid-sized shot gun and paired end } \\
\text { libraries using } 454 \text { sequencing in GS FLX. }\end{array}$ \\
\hline 14 & $\begin{array}{l}\text { Phoenix dactylifera (Date } \\
\text { palm), Al-Dous et al (2011) }\end{array}$ & $\begin{array}{l}\text { Small insert shotgun paired end libraries } \\
\text { were sequenced using GA IIx from } \\
\text { Illumina. }\end{array}$ \\
\hline 15 & $\begin{array}{l}\text { Prunus mume (Chinese plum), } \\
\text { Zhang et al (2012) }\end{array}$ & $\begin{array}{l}\text { Small to large insert sized paired end } \\
\text { libraries sequenced using Illumina's } \\
\text { HiSeq2000 platform. }\end{array}$ \\
\hline 16 & $\begin{array}{l}\text { Pyrus bretschneideri (Chinese } \\
\text { white pear), Wu et al (2012) }\end{array}$ & $\begin{array}{l}\text { A heterogenous approach of combining } \\
\text { sequencing data from small insert } \\
\text { shotgun paired end libraries from } \\
\text { individual BACs, large to very large insert } \\
\text { shotgun mate pair and small sized paired } \\
\text { end libraries, all sequenced using HiSeq } \\
2000 \text { from Illumina. }\end{array}$ \\
\hline 17 & $\begin{array}{l}\text { Prunus persica (Peach), Verde } \\
\text { et al (2013) }\end{array}$ & $\begin{array}{l}\text { Small to large sized shot gun libraries in } \\
\text { plasmids, fosmids were sequenced using } \\
\text { Sanger sequencing on } A B I 3730 X L \text { DNA } \\
\text { Analyzer and BAC end sequencing on the } \\
\text { same platform used for assembly. }\end{array}$ \\
\hline 18 & $\begin{array}{l}\text { Actinidia chinensis (Kiwifruit), } \\
\text { a. Huang et al (2013) }\end{array}$ & $\begin{array}{l}\text { a. Small insert paired end sequenced on } \\
\text { HiSeq2000 }\end{array}$ \\
\hline
\end{tabular}




\begin{tabular}{|c|c|c|}
\hline & b. Wu et al (2019) & $\begin{array}{l}\text { b. Small insert paired end libraries on } \\
\text { HiSeq X Ten and SMRT sequencing over } \\
\text { PacBio Sequel and chromosome level } \\
\text { assembly using HiC. }\end{array}$ \\
\hline 19 & $\begin{array}{l}\text { Pyrus communis (European } \\
\text { pear), Chagne et al (2014) }\end{array}$ & $\begin{array}{l}\text { Small to large insert shotgun paired end } \\
\text { library sequenced on Illumina's GA II } \\
\text { sequencer and BAC end sequencing } \\
\text { using capillary sequencer. }\end{array}$ \\
\hline 20 & $\begin{array}{l}\text { Citrus sinensis (Sweet } \\
\text { orange), Xu et al (2013) }\end{array}$ & $\begin{array}{l}\text { Small shotgun library and mid and large } \\
\text { insert paired end libraries, both } \\
\text { sequenced using GS FLX+ from Roche. }\end{array}$ \\
\hline 21 & $\begin{array}{l}\text { Citrus clementina } \\
\text { (Clementine), Wu et al (2014) }\end{array}$ & $\begin{array}{l}\text { Medium to large insert shotgun plasmid } \\
\text { libraries and Bac and fosmid ends } \\
\text { sequenced using Sanger sequencing on } \\
\mathrm{ABI} 3730 \mathrm{XL} \text { and in addition shotgun } \\
\text { single end sequencing using } 454 \\
\text { technology. }\end{array}$ \\
\hline 22 & $\begin{array}{ll}\text { Ziziphus jujuba } & \text { (Jujube), } \\
\text { Huang et al (2016) } & \end{array}$ & $\begin{array}{l}\text { Small to very large insert shotgun libraries } \\
\text { sequenced using HiSeq } 2000 \text { from } \\
\text { Illumina. }\end{array}$ \\
\hline 23 & $\begin{array}{l}\text { Cocos nucifera (Coconut), } \\
\text { Xiao et al (2017) }\end{array}$ & $\begin{array}{l}\text { Multiple small insert paired end and } \\
\text { medium to very large insert mate pair } \\
\text { libraries were sequenced using HiSeq } \\
4000\end{array}$ \\
\hline 24 & $\begin{array}{l}\text { Ficus carica (Fig), Barghini et } \\
\text { al (2017) }\end{array}$ & $\begin{array}{l}\text { Multiple small insert paired end libraries } \\
\text { sequenced using MiSeq and HiSeq2000. }\end{array}$ \\
\hline 25 & $\begin{array}{l}\text { Rubus occidentalis (Black } \\
\text { raspberry), a. VanBuren et al } \\
(2016)\end{array}$ & $\begin{array}{l}\text { a. Small to medium insert paired end } \\
\text { libraries sequenced using HiSeq } 2000 \text {. }\end{array}$ \\
\hline
\end{tabular}




\begin{tabular}{|c|c|c|}
\hline & b. VanBuren et al (2018) & $\begin{array}{l}\text { b. PacBio and HiC used to improve over } \\
\text { VanBuren et al } 2016 \text {. }\end{array}$ \\
\hline 26 & $\begin{array}{l}\text { Prunus avium (Sweet cherry), } \\
\text { Shirasawa et al (2017) }\end{array}$ & $\begin{array}{l}\text { Small insert paired end and small to large } \\
\text { insert mate pair libraries sequenced on } \\
\text { HiSeq2000 }\end{array}$ \\
\hline 27 & $\begin{array}{l}\text { Moringa oleifera (Drumstik) } \\
\text { Chang et al (2018), African } \\
\text { Orphan Crops Consortium }\end{array}$ & $\begin{array}{l}\text { Multiple small insert paired end libraries } \\
\text { sequenced using HiSeq } 4000 \text {. }\end{array}$ \\
\hline 28 & $\begin{array}{l}\text { Persea americana (Avocado), } \\
\text { Rendón-Anaya et al (2019) }\end{array}$ & $\begin{array}{l}\text { Multiple accessions sequenced using } \\
\text { small insert paired end and small to } \\
\text { medium sized long read mate pair } \\
\text { libraries on 454-FLX (Roche) and } \\
\text { HiSeq2000. A BAC library was also } \\
\text { generated and sequenced using shot gun } \\
\text { sequencing and end sequenced using } \\
\text { traditional Sanger sequencing. SMRT } \\
\text { long read sequencing using PacBio and } \\
\text { genome anchored using genetic linkage } \\
\text { map. }\end{array}$ \\
\hline 29 & $\begin{array}{l}\text { Sclerocarya birrea (Marula), } \\
\text { Chang et al (2018), African } \\
\text { Orphan Crops Consortium }\end{array}$ & $\begin{array}{l}\text { Multiple small insert paired end libraries } \\
\text { and medium insert size mate pair libraries } \\
\text { sequenced using HiSeq } 4000 \text {. }\end{array}$ \\
\hline 30 & $\begin{array}{l}\text { Diospyros spp. (Persimmon) } \\
\text { a. Diospyros oleifera } \\
\text { (Persimmon), Zhu et al } \\
\text { (2019a) }\end{array}$ & $\begin{array}{l}\text { a. Multiple small insert libraries and small } \\
\text { to large insert mate pair libraries } \\
\text { sequenced using HiSeq2500, SMRT } \\
\text { sequencing using PacBio RS II and } \\
\text { chromosome level assembly using HiC. } \\
\text { b. Multiple small insert paired end } \\
\text { libraries sequenced using HiSeq2500 and } \\
\text { HiSeq4000 and large insert libraries }\end{array}$ \\
\hline
\end{tabular}




\begin{tabular}{|c|c|c|}
\hline & $\begin{array}{l}\text { b. Diospyros lotus } \\
\text { (Persimmon), Akagi et al } \\
(2020)\end{array}$ & $\begin{array}{l}\text { sequenced using PacBio RSII. The } \\
\text { chromosome level maps were assembled } \\
\text { using genetic linkage maps created using } \\
\text { RAD-seq markers. }\end{array}$ \\
\hline 31 & $\begin{array}{l}\text { Artocarpus altilis (Breadfruit), } \\
\text { Sahu et al (2020), African } \\
\text { Orphan Crops Consortium }\end{array}$ & $\begin{array}{l}\text { Multiple small insert paired end libraries } \\
\text { sequenced using HiSeq } 4000 \text {. }\end{array}$ \\
\hline 32 & $\begin{array}{l}\text { Artocarpus heterophyllus } \\
\text { (Jackfruit), Sahu et al (2020), } \\
\text { African Orphan Crops } \\
\text { Consortium }\end{array}$ & $\begin{array}{l}\text { Multiple small insert paired end libraries } \\
\text { sequenced using HiSeq } 4000 .\end{array}$ \\
\hline 33 & $\begin{array}{l}\text { Mangifera indica (Mango), } \\
\text { Singh et al 2018, Wang et al } \\
(2020)\end{array}$ & $\begin{array}{l}\text { Small insert paired end and small to } \\
\text { medium sequenced using HiSeq2000 and } \\
\text { MiSeq, SMRT sequencing using PacBio } \\
\text { platform, HiC and mate pair sequencing } \\
\text { for scaffolding and high-density linkage } \\
\text { map used for anchoring contigs onto } \\
\text { chromosomes. }\end{array}$ \\
\hline 34 & $\begin{array}{l}\text { Theobroma cacao (Cocoa) } \\
\text { a. Argout et al (2011) } \\
\text { b. Motamayor et al (2013) }\end{array}$ & $\begin{array}{l}\text { a. Single end and paired end reads from } \\
\text { Roche's GS FLX, paired end reads from } \\
\text { Illumina's GA IIX, and BAC ends } \\
\text { sequenced using ABI } 3730 X L \\
\text { b. Small to very large insert paired end } \\
\text { libraries were sequenced using GA IIx } \\
\text { from Illumina. } \\
\text { c. Multiple small insert paired end libraries } \\
\text { sequenced using HISeq } 2000 / 2500 \text {. }\end{array}$ \\
\hline 35 & $\begin{array}{l}\text { Azadirachta indica (Neem) } \\
\text { a. Krishnan et al (2012) }\end{array}$ & $\begin{array}{l}\text { a. Small insert paired end and medium to } \\
\text { large insert mate pair libraries sequenced } \\
\text { using Illumina's GA IIx; small insert }\end{array}$ \\
\hline
\end{tabular}




\begin{tabular}{|c|c|c|}
\hline & b. Krishnan et al (2016) & $\begin{array}{l}\text { shotgun libraries sequenced by } \\
\text { lonTorrent } \mathrm{PGM} \text { and shotgun } \\
\text { sequencing on } \mathrm{ABI} 3500 \text { capillary } \\
\text { sequencer. } \\
\text { b. The earlier assembly from Krishnan et } \\
\text { al. (2012) was improved using large insert } \\
\text { mate pair libraries sequenced using } \\
\text { HiSeq and PacBio sequencing. }\end{array}$ \\
\hline 36 & $\begin{array}{l}\text { Elaeis guineensis (African oil } \\
\text { palm), Singh et al (2013) }\end{array}$ & $\begin{array}{l}\text { Small and very large insert paired end } \\
\text { libraries were sequenced using GS FLX } \\
\text { Titanium and BAC ends were sequenced } \\
\text { using Sanger sequencing on } A B I 3730 \text {. }\end{array}$ \\
\hline 37 & $\begin{array}{l}\text { Morus notabilis (Mulberry), He } \\
\text { et al (2013) }\end{array}$ & $\begin{array}{l}\text { Multiple small insert paired end and long } \\
\text { insert mate-pair libraries sequenced on } \\
\text { Hiseq2000. }\end{array}$ \\
\hline 38 & $\begin{array}{l}\text { Hevea brasiliensis (Rubber } \\
\text { tree) } \\
\text { a. Rahman et al (2013) } \\
\text { b. Lau et al (2016) }\end{array}$ & $\begin{array}{l}\text { a. Multiple shotgun small-insert paired } \\
\text { end libraries sequenced using Illumina, } \\
\text { Roche/454, and SOLID platforms. } \\
\text { b. Shotgun paired end and mate pair } \\
\text { libraries sequenced using Illumina's } \\
\text { HiSeq2500 and MiSeq and in addition } \\
\text { SMRT sequencing using PacBio RS II } \\
\text { sequencer. } \\
\text { c. Small insert single end and paired end } \\
\text { sequencing on } 454 \text { GS-FLX+, Illumina's } \\
\text { HiSeq2000, and lond read sequencing } \\
\text { using PacBio RS II. } \\
\text { d. Long read sequencing using PacBio } \\
\text { and chromosome level assembly using } \\
\text { HiC. }\end{array}$ \\
\hline
\end{tabular}




\begin{tabular}{|c|c|c|}
\hline 39 & $\begin{array}{l}\text { Ginkgo biloba (Ginkgo), Guan } \\
\text { et al (2016) }\end{array}$ & $\begin{array}{l}\text { Small to very large insert paired end } \\
\text { libraries were sequenced using HiSeq } \\
2000 / 4000 \text { from Illumina. }\end{array}$ \\
\hline 40 & $\begin{array}{l}\text { Macadamia integrifolia } \\
\text { (Macademia nut), Nock et al } \\
(2016)\end{array}$ & $\begin{array}{l}\text { Small insert paired end and medium } \\
\text { insert mate pair libraries sequenced using } \\
\text { GA IIx and HiSeq2000. }\end{array}$ \\
\hline 41 & $\begin{array}{l}\text { Juglans spp. (Walnut) } \\
\text { a. Juglans regia, Martinez- } \\
\text { Garcia et al (2016) } \\
\text { b. Juglans regia×J. } \\
\text { microcarpa by Zhu et al } \\
\text { (2019b) } \\
\text { C. Juglans mandshurica, J. } \\
\text { regia, J. nigra, Bai et al (2018) }\end{array}$ & $\begin{array}{l}\text { a. Mate-pair and paired-end small insert } \\
\text { genomic libraries sequenced using } \\
\text { Illumina's HiSeq2500 and SMRT using } \\
\text { PacBio RS II } \\
\text { b. SMRT sequencing using PacBio RS II } \\
\text { and optical sequencing } \\
\text { c. Paired end small insert sequenced on } \\
\text { HiSeq2500 and long insert jumping } \\
\text { libraries sequenced on HiSeq X ten. }\end{array}$ \\
\hline 42 & $\begin{array}{l}\text { Faidherbia albida (White } \\
\text { acacia), Chang et al (2018) } \\
\text { also African Orphan Crops } \\
\text { Consortium }\end{array}$ & $\begin{array}{l}\text { Multiple small insert paired end libraries } \\
\text { and medium insert size mate pair libraries } \\
\text { sequenced using HiSeq } 4000 \text {. }\end{array}$ \\
\hline 43 & $\begin{array}{l}\text { Polygonum cuspidatum } \\
\text { (Japanese Knotweed), Zhang } \\
\text { et al (2019) }\end{array}$ & $\begin{array}{l}\text { Small insert paired end libraries and small } \\
\text { to long insert mate pair libraries } \\
\text { sequenced using HiSeq2500. }\end{array}$ \\
\hline 44 & $\begin{array}{l}\text { Santalum album } \\
\text { (Sandalwood) } \\
\text { a. Mahesh et al (2018) }\end{array}$ & $\begin{array}{l}\text { a. Multiple small insert paired end and } \\
\text { small to medium size mate pair libraries } \\
\text { sequenced using HiSeq } 1000 \text {. } \\
\text { b. Small insert paired end libraries } \\
\text { sequenced using MiSeq and } \\
\text { NextSeq500. }\end{array}$ \\
\hline
\end{tabular}




\section{APPLICATION OF GENOMIC-BASED TECHNOLOGIES FOR PERENNIAL WOODY AND}

TREE SPECIES

Many of the tree species have not undergone extensive domestication processes as seen in field crops such as wheat, rice, maize and edible legumes. The domestication processes in these field crops have corrected the 'wild traits' primarily by developing shattering resistance, improving plant stature, cooking quality, reproductive biology quality, and by enhancing field manageability. However, this was followed by the process of selection and crop improvement which made these crops more productive and economical under crop husbandry practices; this improved their nutritional quality by enriching them with energy-rich carbohydrates (for cereals) and proteins (for legumes). Though there are many similarities between the domestication of annual crops and tree crops at morphological level, tree domestication processes have some important differences such as diversity of morphology, growth habits and physiology, among many other traits. Hardwood trees show extensive variation in wood anatomy, leaf morphology, whole-tree architecture, secondary metabolism and numerous adaptive traits (Groover and Crook 2017). Reflecting their evolutionary history, hardwood tree genomes display divergent chromosomal architectures, with multiple ancestral wholegenome duplications and rearrangements, gene family expansions, and many segmental deletions across lineages (Tuskan et al 2006), besides, some changes in vegetative forms like thorny to thorn-less, ploidy level, and plant stature from large to dwarf. Further improvements in productivity and quality traits resulted from combinations of clonal propagation and human selection.

A high genetic diversity, clonal mode of propagation, and perennial behaviour of the trees do put some bottlenecks for employing traditional crop breeding methodologies. Nevertheless, they also offer some specific advantages. A high genetic diversity provides a wider spectrum of genetic variability available for selection; clonal propagation helps to multiply true-to-type seedlings; and perennial behaviour allows recording of observations in different spatial and time scales. As the role of genetics in these traits is now well known either in model systems and/or cultivated crops and trees, it is possible 
to expedite improvement activities by using modern approaches like genomics and its application in QTL mapping, genomics-assisted breeding, genome-wide association studies (GWAS), and genomic selection (GS) (Hickey et al 2017). The first step towards this is to sequence their genomes, develop SNP assaying technologies, and then use them for genomics-assisted or genomics-based improvement processes. However, substantial investment is required to develop suitable mapping populations, experimental designs, analytical tools, and to translate these findings to develop longterm breeding programmes and reproducible genetic gains.

Some studies in tree species like eucalyptus, poplar, pine, spruce, apple, peach, oil palm, citrus, cocoa, grape and macadamia used genomics-based technologies to link or associate a few economically-important traits with SNP variants. These studies indicate that a sufficient amount of groundwork has already been carried out to start the genomics-assisted selection. Hence, the era of field application in tree improvement is not too far away.

\section{CURRENT SCENARIO OF TREE GENOMICS RESEARCH GLOBALLY}

In India, trees have historically been an important part of the agricultural landscape. While a number of tree species have been traditionally grown, a few of them gained momentum because of their economic, social or cultural values. Here, we give a global research account of a few species that have been systematically collected, curated and maintained in genebanks across India.

\section{i. $\quad$ Azadirachta indica (Neem)}

Azadirachta indica A. Juss (Neem) belongs to the family Meliaceae and order Rutales. It is an evergreen tree native to the Indian sub-continent. Neem is an excellent multipurpose evergreen, tall and fast-growing species, with copious traditional values. It has medicinal and biological properties, seed oil which is used as bio-pesticide, and is an excellent source of animal feed and timber. Further, it consists of $2 n=28$ of chromosome. Neem timber is durable even in extended exposed conditions and is resistant to termites 
and wood worms. Its wood is used for firewood and charcoal, and is of excellent quality. The Government of India also promotes Neem Coated Urea (NCU), a fertilizer from neem oil among various agricultural schemes initiated to boost the growth of wheat and paddy. ICAR-Central Agroforestry Research Institute (CAFRI), Jhansi has 170 provenances of neem collected from various states of India. They have conducted studies on reproductive biology, vegetative propagation techniques, variability on fruit and seed traits as neem seed oil yield and azadirachtin content, and evaluated neem germplasm for straightness and other growth-related traits (Gupta et al 2011). Neem is a crosspollinated species, mainly pollinated through insects and wind.

Neem possesses more useful non-wood products (leaves, bark, flowers, fruits, seed, gum, oil and Neem cake) than any other tree species. Seed kernels constitute 50-60\% of seed weight and $25 \%$ of the fruit. Percentage of kernel fat ranges from $30-50 \%$. The oil is brownish yellow, non-drying with an acrid taste and unpleasant odour. Several valuable bioactive substances from limonoids class of triterpenoids were found in Neem oil. Azadirachtin is the most important bio-active compound, having effective biological functions and huge commercial value. Its commercial formulations are toxic against a large range of insect species, whilst retaining very low mammalian toxicity. The genome size of Neem is $384 \mathrm{Mbp}$ (Ohri et al 2004).

The Neem population was predominantly allogamous and polycarpy was found to be a possible way of avoiding inbreeding (Kundu 1999). Randomly amplified polymorphic DNA (RAPD) analysis was employed to assess genetic divergence among 29 neem accessions collected from two agro-ecological regions of India (11 agro-climatic subzones) (Deshwal et al 2003). The first attempt to sequence the Neem genome was made by Krishnan et al (2012). The draft genome sequence released was assembled to Scaffold N50 of 452,028 bp and Scaffold N90 of 56,222 bp. They reported about 20,000 genes with an average transcript length of $1.69 \mathrm{Kbp}$ and $A$. indica's evolutionary closeness to the citrus species was verified by both molecular phylogenetic analyses and sequence similarity. An improved genome assembly was generated by the same lab 
(Krishnan et al 2016) using additional short reads from Illumina and long reads from Pacific Biosciences SMRT sequencer. The updated genome assembly (v2.0) yielded a 3- and 3.5-fold increase in N50 and N75, respectively. Kuravati et al (2015) also performed sequencing in Illumina and 454 sequencing platforms. They assembled 267 Mbp, which accounts for $70 \%$ of the estimated size of the neem genome and predicted 44,495 genes. Some transcriptome studies related to transcriptomics for identifying genes related to the terpenoid biosynthesis pathway are also documented in neem (Krishnan et al 2012, Wang et al 2016, Bhambhani et al 2017). Hodgson et al (2019) identified key enzymes responsible for protolimonoid biosynthesis thus opening the door for understanding azadirachtin synthesis in neem. In their study on 3 limonoid-producing species (A. indica, Melia azedarach and Citrus sinensis), they characterized tirucalla-7, 24-dien-3 $\beta$-ol synthase OSCs (AiOSC1, MaOSC1, CsOSC1) as enzymes responsible for early-stage protolimonoid synthesis.

\section{ii. Dalbergia sissoo (North Indian rosewood)}

The genus Dalbergia, which comprises approximately 250 species of trees, shrubs and woody climbers is widely distributed in tropical and sub-tropical regions of the world, with Amazonia, Madagascar, Africa and Indonesia being considered centres of high diversity. Among various species, Dalbergia sissoo commonly known as North Indian rosewood or sissoo, is a fast-growing, hardy deciduous tree native to the Indian subcontinent and Southern Iran. It is one of the important multipurpose tree species primarily distributed from the foothills of the Himalayan tract of India and Pakistan. It is used for high-quality furniture, cabinets, decorative veneer, marine and aircraft grade plywood, ornamental turnery, carving, engraving, tool handles and sporting goods (Chaturvedi et al 2017). Due to its multipurpose use, coupled with wider adaptation in different climate and soil conditions, this species should be prioritized for agroforestry systems.

ICAR-CAFRI, Jhansi, and its network All India Coordinated Research Project on Agroforestry (AICRPAF) and ICFRE-Forest Research Institute (FRI), Dehradun have done much tree improvement work on shisham. ICAR-CAFRI has collected 14 accessions 
from different parts of central India, which have been evaluated for rapid growth, clear bole and canopy. It has further identified superior genotypes- shisham bundle 2 (PT-2) and shisham bundle 6 (PT-6) for straightness and higher bole volume, which has been registered as genetic stock at ICAR-NBPGR, New Delhi. AICRPAF Centre at GBPUA\&T, Pantnagar proposed Shisham PS-52 for registration as this genotype had unique features of straight bole, higher height and diameter growth. ICFRE-FRI, Dehradun released the Shisham variety FRI-DS-14, which shows resistance to the devastating disease of die-back. Besides, the variety has an excellent bole form which increases its value in the timber industry. Further improvement of these species can be effected using recent biotechnological approaches, particularly genomics-based, next generation sequencing (NGS) and genotyping-by-sequencing (GBS) techniques.

Dalbergia belongs to the sub-family Mimosoideae within the family Fabaceae and includes several valuable timber-yielding species of economic importance. Dalbergia sissoo is a diploid species with $2 n=20$ and is mainly self-pollinated by honey bees, beetles, butterflies and thrips. Genomics study in this species is at a very initial level. Some research related to genetic diversity has been carried out with molecular markers. Javaid et al (2014) assessed genetic diversity in D. sissoo in vegetations from Lahore, Gujranwala and Sialkot districts of Pakistan and discovered that polymorphism ranged from $27.27 \%$ to $89.50 \%$. Random amplified polymorphic DNA (RAPD) markers were used to study the genetic relationships among 10 species and genetic diversity in 49 genotypes of Dalbergia sisso in India (Hiremath and Nagasampige 2004, Dobhal et al 2019). Complete chloroplast genome sequenced and compared in nine Dalbergia species including Dalbergia sissoo and chloroplast genomes were conserved to genome size, structure and gene content, and showed low sequence divergence. Eight mutation hotspots, namely, six intergenic spacer regions (trnL-trnT, atpA-trnG, rps16-accD, petG-psaJ, ndhF-trnL, and ndhG-ndhl) and two coding regions (ycf1a and $y c f 1 b)$ were also identified (Song et al 2019). 


\section{iii. Tectona grandis (Teak)}

Tectona grandis L. (Teak) belonging to the mint family Lamiaceae (earlier member of Verbenaceae) is one of the world's highly valued tropical timber species that occurs naturally in India, Laos, Myanmar and Thailand. In addition to this, teak is commercially grown in many countries, such as Sri Lanka, Bangladesh and China in Asia; Ghana, Nigeria, Ivory Coast, Senegal, Togo and Benin in West Africa; Sudan and Tanzania in East Africa; Trinidad, Puerto Rico and Panama in Central America; and Brazil and Ecuador in South America. The timber is highly valued because of its extreme durability, strength, stability as well as resistance to pests. Quinones and other extractives found abundant in the teakwood are responsible for its anti-termite and anti-fungal properties, conferring the longevity of timber. Thus, the wood is used in building ships, railway carriages, sleepers, construction, furniture, veneer, and carving owing to its admirable timber qualities and aesthetical properties. Teak has been an out-crossing species, but to some extent, up to $1-2 \%$ self-pollination is possible. It is a diploid species with $2 n=26$ chromosomes. Zhao et al (2019) identified 14 clusters of tandem-duplicated terpene synthases (TPSs), genes central to the biosynthesis of terpenes, which are involved in plant defense and pollinator attraction. Transcriptome analysis revealed 10 TPSs highly expressed in woody tissues, of which eight were in tandem, revealing the importance of resolving tandemly duplicated genes and the quality of the assembly and annotation. Galeano et al (2019) studied the physiological and molecular responses to drought stress in teak and revealed that TgTPS1, TgDREB1, TgAREB1 and TgPIP1 along with TgHSP1, $T g H S P 2, T g H S P 3$ and $T g B I$ (other stress-related genes) showed that with moderate treatment, TgTPS1, TgDREB1, TgAREB1, TgPIP1, TgHSP3 and TgBI genes had higher expression than the control treatment. However, with severe treatment, only TgTPS1 and TgDREB1 showed higher expression than the control treatment. Thus it was concluded that these physiological and biochemical adjustments in leaves and genetic changes in roots under severe and prolonged water shortage situations can be a limiting factor for teak plantlet growth. Galeano et al (2015) presented a widely expressed gene catalog for $T$. grandis using Illumina technology and the de novo assembly. A total of 462,260 transcripts were obtained, with 1,502 and 931 genes differentially expressed for 
stem and branch secondary xylem, respectively, during age transition. Analysis of stem and branch secondary xylem indicates substantial similarity in gene ontologies including carbohydrate enzymes, response to stress, protein binding, and allowed us to find transcription factors and heat-shock proteins which are differentially expressed. TgMYB1 displays an MYB domain and a predicted coiled-coil (CC) domain, while TgMYB2, TgMYB3 and TgMYB4 showed R2R3-MYB domain and grouped with MYBs from several gymnosperms and flowering plants. TgMYB1, TgMYB4, and TgCES presented a higher expression in mature secondary xylem, in contrast to TgMYB2, TgHsp1, TgHsp2, TgHsp3 and TgBi whose expression is higher in young lignified tissues. TgMYB3 is expressed at a lower level in secondary xylem. Yasodha et al (2018) assembled a draft genome of $317 \mathrm{Mbp}$ at 151 coverage and annotated 36,172 proteincoding genes. Approximately $11.18 \%$ of the genome was repetitive. Microsatellites or simple sequence repeats (SSRs) are undoubtedly the most informative markers in genotyping, genetics, and applied breeding applications. They generated 182,712 SSRs at the whole genome level, of which, 170,574 perfect SSRs were found; 16,252 perfect SSRs showed in silico polymorphisms across six genotypes, suggesting their promising use in genetic conservation and tree improvement programmes. Genomic SSR markers developed in this study could make a significant contribution to the conservation and management of teak genetic resources.

Mohammad et al (2017) studied the effect of discrete (individual) and mixed (bulk) genomic DNA on genetic diversity estimates and population structure in Teak. They recommended strict guarding of identities of genotypes within the collected samples for obtaining precise estimates and drawing accurate conclusions about the genetic diversity and clustering of populations. They compared the genetic variation detected and genetic relationships inferred in five teak populations via 10 genomic DNA samples per population each of either single-seed or bulk of 3- or 5-seed with the help of ISSR markers. 
Teak populations from Western Ghats and Central India were reported to be genetically distinct as revealed by RAPD markers. The intra-population variation was found to be substantially higher $(78 \%)$ when compared to the inter-population variation (Nicodemus et al 2005).

Vaishnav et al (2015) used AFLP markers for analysis of genetic diversity and structure of teak in India. Five AFLP primer combinations were employed for analysis of genetic diversity, differentiation and structure of 96 genotypes of teak from 10 natural locations in India. The primer combinations detected maximum polymorphism in the teak genome. The population genetic structure revealed two distinct centres of teak diversity, i.e., central India and peninsular India. The very high proportion of genetic diversity residing within locations encourages the intensive selection and collection of diverse superior genotypes from each location for the conservation of germplasm and genetic improvement of teak.

Narayanan et al (2008) assessed the comparative efficacy of different DNA extraction methods for PCR-based assay in teak. Four extraction methods and sample types were evaluated for yield, quality and suitability of genomic DNA for ISSR (inter simple sequence repeats) marker amplification by PCR in teak. Using identical PCR conditions, DNA extraction methods, and sample types affected amplifications of ISSR markers with a pattern: seedling > graft > tree leaves. Genomic DNA of seed samples contained a high amount of protein and showed no ISSR amplification, which was overcome by the inclusion of proteinase $\mathrm{K}$ in SDS-based extraction method.

Vaishnav and Ansari (2018) investigated the genetic differentiation of teak metapopulation in India to geographical and climatic variations employing dominant ISSR markers followed by Bayesian statistical analysis to understand the adaptability of the species. Ansari et al (2012) utilized ISSR markers for analysis of molecular diversity and genetic structure of Indian teak populations. Twenty-nine populations of teak were collected from central and peninsular India and five ISSR primers were used for the 
analysis of genetic diversity and structure. The cluster analysis distinguished the drier teak populations of central India from the moist teak populations of south India, which was also confirmed by Principal Coordinate Analysis. The findings advocate the need not only for enhancing selection intensity for a large number of plus trees, but also for laying out a greater number of in situ conservation plots within natural populations of each cluster for germplasm conservation of teak. The aim is to improve teak productivity and quality in future.

\section{iv. Leucaena leucocephala (Leucaena)}

Leucaena leucocephala (Lam.) de Wit. belongs to the Mimosoideae family and is indigenous to Colombia, Costa Rica, El Salvador, Guatemala, Honduras, Mexico, Nicaragua, Panama, Spain and USA. It is widely distributed throughout the world and has become naturalized. Leucaena is an evergreen species; however, under frost or prolonged drought it sheds its leaves, but regains them once normal conditions return. It has multiple uses and is, therefore, referred to as a "miracle tree" worldwide. The leaves are highly nutritious for ruminants. The species is widely utilized for fuelwood, pulpwood, small timber, green manure, charcoal, parquet flooring and fencing. The genus Leucaena comprises 19 diploid and five tetraploid species. L. leucocephala is an allotertraploid species $(2 n=104)$ which originated from natural hybridization two diploid species $L$. pulverulenta as the maternal parent and $L$. cruziana as the paternal parent (Govindarajulu et al 2011). It is mostly self-pollinated and consists of bisexual flowers (each flower of each individual has both male and female structures). Boff and SchifinoWittmann (2003) also argued segmental alloploid nature and did not rule out autotetraploid nature just based on cytological data. Genomic research in this species is still at the initial stages. Few studies related to transcriptomics have been documented to date. Negi et al (2011) identified some species-specific genes using Interspecies Suppression Subtractive Hybridization (ISSH). They use cDNAs from leucaena and Acacia confusa (acacia) as the tester and driver, respectively, and identified 96 leucaena genes showing homologies to various plant genes with known functions and 46 other genes-encoding hypothetical proteins. Among these, 22 genes 
were related to various stress-related proteins including chitinase, PR-10 protein, type 2 metallothionein, thaumatin-like protein, germin-like protein (GLP), molybdenum cofactor sulfurase (MCSU), aldehyde dehydrogenase, cysteine proteinase and Kunitz trypsin inhibitor.

An improved method for RNA extraction from Leucaena leucocephala is also standardized. This method can be extended to woody leguminous species, Acacia koa and Acacia gray to facilitate genetic studies (Ishihara et al 2016a). Ishihara et al (2016b) did Transcriptome Analysis by illumina sequencing followed by SOAPdenovo assembly and generated over 120,000 unigenes from roots and shoots combined. Approximately $80 \%$ of identified genes were annotated of Identification of Highly Expressed Genes in Roots and Shoots. Microarray and q-PCR are used for further validation of the expression of unigenes. Root and shoot-specific sequences were also identified. Upregulated sequences in the root were mostly represented by unigenes that were related to secondary metabolism, while in the shoot, up-regulated sequences were mostly represented by unigenes that were involved in carbohydrate and lipid metabolism. The unigenes sharing homology with terpenoid biosynthesis genes and a nicotianamine synthase gene were up-regulated more than 100-fold in the root, which indicates that these genes may have important roles in high-stress tolerance of Leucaena.

\section{v. Melia dubia (Malabar Neem)}

Melia dubia Cav. syn. M. composita Willd. (Family: Meliaceae), commonly known as Burma dek, white cedar, Malabar neem or drek, is a deciduous tree, native to the Indian sub-continent. Melia dubia is endemic to certain pockets of the Western Ghats in India. It is found in tropical moist and tropical dry deciduous forests. Naturally, it is distributed in India, Sri Lanka, Malaysia, Bhutan, Myanmar, Australia and Africa. However, in India, it is mostly found in small pockets of Sikkim Himalaya, Upper Assam, Khasi Hills, Orissa, North Bengal, Deccan Plateau and Southern India at elevations ranging from 600-1,800 $\mathrm{m}$ above MSL. The species is widely used for pulp \& paper, veneer making, packing cases, ceiling planks, building purposes, agricultural implements, pencils, matchboxes, 
splints, kattamarans, musical instruments and tea boxes. Although the species is reported to be predominantly self-fertilized, some cases of open pollination have been reported. The chromosome numbers of Melia dubia is $2 n=28$. Some studies related to genetic diversity using different morphological traits (Kumar et al 2013) and molecular markers has been reported in this species. Results from the RAPD used to evaluate the genetic diversity in populations of Melia dubia from different agro-climatic regions of India showed similarity indices ranged from 0.80 to 0.90 . Similarly, genetic variation was also assessed using ISSR markers in 11 natural populations and seven plantations across eight districts of Karnataka, comprising 232 samples through 15 Markers (Rawat et al 2018). Phenotyping using pilodyn as a tool was also carried out followed by selective genotyping and preliminary genetic diversity estimation for wood basic density mainly using wood stiffness as a trait and SSR markers (Joshi et al 2018, 2019).

\section{vi. Gmelina arborea (White teak)}

Gmelina arborea Roxb is a fast-growing indigenous multipurpose tree species which produces one of the best quality timbers in India. It is a medium- to large-sized deciduous tree and can grow up to $40 \mathrm{~m}$ in height. It is endemic to Bangladesh, Cambodia, China, India, Japan, Laos, Myanmar, Nepal, Pakistan, Sri Lanka, Thailand and Viet Nam. In India, it is found in the eastern sub-Himalayan tract, Indo-Gangetic plains, Aravali Hills, central India, western Peninsula and western Himalayas. It grows well in eastern sub-Himalayan belt but extends into mixed-deciduous forests of central India and sal forests of Uttar Pradesh, Bihar and Orissa, and occasionally in wet evergreen forests of the Western Ghats (Chaturvedi et al 2017).

The tree has been commercially grown due to its woody timber used for pulp, paper, medium density fibre board, laminated veneer lumber, wood cement composites, particle board, furniture, furniture interiors, plywood interiors, finger jointed lumber, door panelling, pallets, pencils and match sticks. The breeding system of white teak involves both self- and cross-pollination. Pollination is entomophilous, i.e., by insects. Naik et al (2009) reported $41 \%$ and $59 \%$ genetic diversity within and between Gmelina arborea 
population using ISSR primers and observed positively correlated genetic differentiation among six Indian populations to geographic distance $(r=0.626, P=0.029)$.

Shankar et al (2009) described a modified protocol based on Dellaporta et al (1983) for isolating high-quality DNA from dried leaves of Gmelina arborea, which is suitable for molecular analysis. Manokar et al(2018) designed genetic markers for G. arborea and G. asiatica based on the nuclear ribosomal DNA-internal transcribed spacer 1 (ITS1) region to distinguish them from substitutes and adulterants.

\section{vii. Eucalyptus grandis (Rose gum)}

Eucalyptus grandis Hill ex Maid. belongs to the Myrtaceae family and is commonly known as red gum, rose gum and flooded gum. It is native to Australia but was introduced to several countries including Australia, Angola, Argentina, Brazil, Ethiopia, India, Kenya, South Africa, Tanzania, Uganda, Uruguay, Zambia and Zimbabwe. The flowers are bisexual, with fertile male and female organs on the same flower. Pollination is dependent on insects or animal vectors. Like many Eucalyptus species, it has a tendency to out-breed. The species is used for pulpwood, plywood, poles, timber, honey production, packaging cases and fuelwood.

Eucalyptus species and hybrids represent the most widely cultivated hardwood biomass crop globally, and Eucalyptus grandis (rose gum) clonal genotype 'BRASUZ1' was selected as the reference for the genus. Published in 2014, the E. grandis genome was the first of the order Myrtales and the family Myrtaceae. Key features of the genome included a very high proportion (34\%) and many genes (over 12,500) in tandem duplicate arrays, an ancient genome-wide duplication event and high diversity of gene families encoding plant-specialized metabolites such as phenylpropanoids and terpenes which are important for plant defense and pharmaceutical uses such as eucalyptus oils (Mewalal et al 2017). 
BRASUZ1 was one of the last plant genomes produced exclusively with Sanger technology combined with extensive BAC-end coverage. The result was a high-quality assembly (currently v2.01) comprising $691 \mathrm{Mbp}$ in 4,943 scaffolds with a scaffold N50 of $57.5 \mathrm{Mbp}$, contig N50 of $67 \mathrm{Kbp}$ and 94\% of the estimated $640 \mathrm{Mbp}$ genome in 11 pseudomolecules containing 288 scaffolds longer than $50 \mathrm{Kbp}$. A total of 36,349 proteincoding loci are annotated and the assembly has served as a reference for extensive transcriptomics studies targeting the regulation and biosynthesis of lignocellulosic biomass (Mizrachi et al 2014; Carocha et al 2015; Hussey et al 2015; Soler et al 2015) and in comparative analyses with Arabidopsis (Davin et al 2016) and Populus (Hefer et al 2015; Pinard et al 2015). Other research targets have included terpene biosynthesis (Myburg et al 2014; Kulheim et al 2015), reproductive biology (Vining et al 2015), plant defense (Christie et alet al 2015; Mangwanda et al 2015; Oates et al 2015; Meyer et al 2016) and abiotic interactions (Plett et al 2015; Spokevicius et al 2017). High-throughput transcriptome sequencing in 100 s of segregating interspecific hybrids of $E$. grandis $\times E$. urophylla have been used to perform the first comprehensive systems genetic analysis of wood development in Eucalyptus (Mizrachi et al 2017).

The E. grandis genome has also served as a reference for whole-genome analysis of the causes of inbreeding depression (Hedrick et al 2016) and development of a commercial, multi-species $60 \mathrm{~K}$ SNP genotyping chip tagging $96 \%$ of the genome with 1 SNP every 12-20 Kbp (Silva-Junior et al 2015). The EuCHIP60K has been a key resource in investigating genome-wide recombination, linkage disequilibrium and nucleotide diversity (Silva-Junior and Grattapaglia 2015), carry out genome-wide association (Resende et al 2016; Muller et al 2019) and drive genomic selection in different Eucalyptus species (Duran et al 2017; Tan et al 2017, 2018). Eucalyptus transcriptomics resources are available at https://eucgenie.org. Ongoing and future efforts are focused on understanding genome diversity and evolution in this species-rich genus and other members of Myrtaceae (Grattapaglia et al 2012), including sister genera such as Corymbia for which a genome assembly, soon to be released, revealed conservation but dynamic evolution of terpene genes relative to Eucalyptus (Butler et al 2018). 
Steane et al (2011) tested a set of $>8000$ DArT markers across a range of Eucalyptus species for its utility in high-resolution population and phylogenetic studies which could help in identifying interspecific hybrids and resolve biogeographical disjunctions within species. Myburg et al (2014) have sequenced and assembled more than $94 \%$ of the 640 Mbp genome of Eucalyptus grandis and predicted 36,376 protein-coding genes. Dasgupta et al (2015) identified a total of 2294 SNVs and 479 InDels in E. camaldulensis, 2383 SNVs, and 518 InDels in E. tereticornis, and 1228 SNVs and 409 InDels in E. grandis which could be used for the development of markers supposedly related to wood property traits in Eucalyptus. Sumathi and Ramasamy (2017) amplified 55 alleles from six microsatellite loci in two inter-specific hybrid populations (E. tereticornis $\times E$. grandis and $E$. tereticornis $\times E$. camaldulensis) followed by their sequencing and reported the amplification for target repeat types, except for loci Eg61 and Embra2002.

The genetic diversity estimations using RAPD, ISSR and SSR were conducted at different levels of the population including species, provenances, seed orchards and clones assembled by IFGTB in Eucalyptus spp. (Balasaravanan et al 2005; Chezhian et al 2010) and species-specific ISSR markers were reported in different Eucalyptus species (Balasaravanan et al 2006). Generation of high throughput markers (SNPS and InDels) using the strategy of target capture and deep sequencing of 94 genes involved in wood formation across three Eucalypt species was reported for QTL/Association studies (Dasgupta et al 2015).

\section{viii. Isolation and characterization of cell wall related genes in Eucalyptus tereticornis}

Three full-length developing xylem specific cellulose synthases (EtCesA1, EtCesA2, and EtCesA3) were isolated and characterized from Eucalyptus tereticornis. The differential expression analysis of the three EtCesA genes using qRT-PCR revealed 49to 87-fold relative expression in developing secondary xylem tissues. All three EtCesA 
transcripts were up-regulated by indole acetic acid and gibberellic acid (Sundari and Dasgupta, 2014).

The homeodomain-leucine zipper class III transcription factor gene (EtHB2) was isolated from the leaf tissues of Eucalyptus tereticornis. The complete coding domain sequence was $2535 \mathrm{bp}$ and harbored the signature domains including Homeodomain, Leucine Zipper, START and MEKHLA. Tissue-specific expression profiling of EtHB2 revealed its predominant expression in developing xylem tissues (Dharanishanthi and Ghosh Dasgupta, 2017).

\section{System approach to understanding complex traits in Eucalyptus}

A customized array representing 3,359 water stress-responsive genes were designed to document their expression in E. grandis leaf cuttings subjected to $-0.225 \mathrm{MPa}$ of PEG treatment. The co-expression network was constructed with 915 nodes and 3,454 edges with a degree ranging from two to 45 . Ninety-four (94) GO categories and 117 functional pathways were identified in the network. MCODE analysis generated 27 modules and module 6 with 479 nodes and 1005 edges was identified as the biologically relevant network. The major water-responsive transcripts represented in the module included dehydrin, osmotin, LEA protein, expansin, arabinogalactans, heat shock proteins, major facilitator proteins, ARM repeat proteins, raffinose synthase, tonoplast intrinsic protein and transcription factors like DREB2A, ARF9, AGL24, UNE12, WLIM1 and MYB66, MYB70, MYB55, MYB16 and MYB103. (Ghosh Dasgupta and Dharanishanthi 2017).

The natural variation in expression patterns of 18,987 transcripts expressed in the developing xylem tissues was documented across four phenotypes of Eucalyptus tereticornis with contrasting holocellulose/klason lignin content. The differentially expressed genes across all the phenotypes were used to construct co-expression networks and sub-network 2 with 380 nodes and 17,711 edges were determined as the network of relevance, including 30 major cell wall biogenesis-related transcripts with 2394 interactions and 10 families of transcription factors with 3360 
interactions. EYE [EMBRYO YELLOW] was identified as a major hub transcript with 173 degrees which interacted with known cell wall biogenesis genes. K-mean clustering was also performed for differentially expressed transcripts and two clusters discriminated against the phenotypes based on their holocellulose/klason lignin content. The clusterbased networks were enriched with GOs related to cell wall biogenesis and sugar metabolism (Dharanishanthi and Ghosh Dasgupta 2016).

The expression patterns of 2,651 transcripts representing different pathways governing secondary development were documented across four genotypes of E. tereticornis. A co-expression network was constructed with 330 nodes and 4,512 edges and the degree ranged from 11 to 53 . The network documented $75(22 \%)$ transcription factors with a high degree of interaction. A secondary wall-associated NAC domain transcription factor (SND2) was identified as the top hub transcript with 53 interactions (Dharanishanthi and Ghosh Dasgupta 2018a). Co-expression network was developed for transcription factors expressed during wood formation in E. tereticornis and ethyleneresponsive element-binding factor, EtERF2, was identified as the major hub transcript which co-expressed with other secondary cell walls biogenesis-specific TFs such as: EtSND2, EtVND1, EtVND4, EtVND6, EtMYB70, EtGRAS and EtSCL8 (Dharanishanthi and Ghosh Dasgupta 2018b).

\section{ix. Populus species (Poplar)}

Populus species are the first perennial components to secure recognition as model tree crops for forest tree breeding programmes because of the groundbreaking work in species hybridization, polyploid breeding, and investigations into pathogen resistance during the early part of the twentieth century (Pauley 1949). Poplar is one of the most widely planted species after eucalyptus and pinus for industrial purposes. It is found in temperate regions such as Europe, the Mediterranean basin, Central Asia, Ukraine, Russia, northwest China, North America (between the Canadian prairie and Gulf of Mexico, and over $40^{\circ}$ of longitude between the Atlantic seaboard and the Great Plains), and the Japanese Islands of Sakhali. Stanton et al (2014) reported that the poplar species 
was domesticated in European countries through Eastern cottonwood ( $P$. deltoides) in the late eighteenth century. The total area of planted poplar reported in 2016 was 31.4 million ha, of which 18.3 million ha (58\%) are managed for multiple purposes, 9.4 million ha $(30 \%)$ are primarily for wood production, 2.9 million ha $(9 \%)$ for environmental protection and the balance of 0.9 million ha $(3 \%)$ is managed for biomass production for fuelwood (FAO, 2016). The genus Populus Linn. includes 44 species in five sections like white poplars (Leuce), black poplars (Aigeiros), balsam poplars (Tecamahaca), Leucoides and Turanga. These are widely distributed in the temperate and sub-tropical regions of the Northern Hemisphere (Naithani and Nautiyal 2012).

When the Populus trichocarpa genome, 'Nisqually-1' was released in 2006, it was the first plant genome to use the shotgun sequencing assembly approach, the first genome to create chromosome-level assemblies based on genetic mapping, the first woody perennial genome to be assembled and annotated, as well as the first metagenomic assembly of associated endophytic bacteria and fungi (Tuskan et al 2006). Today, v3.2 contains $423 \mathrm{Mbp}$ [of the $485 \mathrm{Mbp}$ genome] in 1,446 scaffolds with 2,585 gaps. The scaffold N50 metric is $8 \mathrm{Mbp}$ and contig N50 is $205 \mathrm{Kbp}$, with roughly 98\% of the genome in 181 scaffolds. Trained on deep RNAseq data from the Gene Atlas project, there are 41,335 predicted loci and 73,013 protein coding transcripts. Methylation maps are available for 10 tissue types, including bud tissue, callus tissue, female catkins, internode explants, male catkins, phloem, xylem and roots (Vining et al 2012). Over 28 million single nucleotide polymorphisms (SNPs) from re-sequenced data representing over 880 native $P$. trichocarpa genotypes covering the core distribution of the species range are publicly available (Geraldes et al 2013). This SNP resource has been used to characterize the geographic structure and linkage disequilibrium (Slavov et al 2012), detect signatures of selection across the genome (Evans et al 2014) and identify genetic loci associated with various phenotypes based on genome-wide association approaches (Porth et al 2013; Evans et al 2014; McKown et al 2014; Muchero et al 2015; Fahrenkrog et al 2017; Liu et al 2018). The re-sequenced data is currently being assembled into a Populus pan genome, with preliminary data suggesting that there may 
be as many as 20,000 additional gene models that are not included in the current $P$. trichocarpa reference genome annotation (Pinosio et al 2016). The first draft assemblies of Populus deltoides, 'WV94' and Populus tremula $\times$ P. alba hybrid, '717-1B4,' have been sequenced, assembled, and annotated. The assembly for WV94 is approximately 446 Mbp in 1,375 scaffolds, with scaffold N50 of $21.7 \mathrm{Mbp}$ and contig N50 of $590 \mathrm{Kbp}$ and there are 44,853 protein-coding loci. CRISPR-related PAM (protospacer adjacent motif) sites for $P$. tremula $\times P$. alba 717 have been published online at http://aspendb.uga.edu/s717.

Highly contiguous, de novo genome assemblies have also been produced for $P$. euphratica (Ma et al 2014) and $P$. tremula, which greatly widen the phylogenetic sampling of the genus. Ongoing resource development work in Populus includes efforts to expand the tissue type and experimental conditions in the Gene Atlas, enlarge the number of resequenced genotypes from the southern and eastern portions of the range, and release of V4.0 of the $P$. trichocarpa genome based on long-read sequencing and dense genetic maps derived from re-sequencing 1000 progeny from 49 half-sub families. Dozens of genome-wide association studies continue across a broad array of phenotypes and efforts to estimate the somatic mutation rate found in old-growth $P$. trichocarpa are currently underway. Methods to integrate SNP, gene expression, transcription factor binding, gene dosage, methylation, metabolite expression, phenome, and coevolutionary relationships have been developed to generate a systems biology view of the molecular and regulatory interactions that lead to organismal scale traits (Henry et al 2015; Liu et al 2015; Joubert et al 2017, 2018; Weighill et al 2018). New algorithms are being developed to use signal processing techniques as well as explainable artificial intelligence to build better systems biology models. These include methods to discover and model genome-wide epistasis and pleiotropy. Efforts are also underway to gain a comprehensive view of chromatin structure and transcription factor-binding sites (Rao et al 2014). 


\section{x. Acacia species}

The genus Acacia is one of the largest genera in the world, consisting of about 800 species of trees and shrubs in the sub-family Mimosoideae of the pea family, Fabaceae. It is native to tropical and sub-tropical regions of the world. It is mainly found in Australia (where they are called wattles) and Africa, where they are well-known landmarks on the veld and savanna. Acacias are commonly cultivated throughout temperate, tropical and desert regions, and include numerous distinctive growth forms with profusion of yellow or white flower clusters. Acacias also provide us with many useful products, from beautiful hardwoods to water-soluble gums used as a thickening agent in your favourite frozen dessert. Several acacia species are used commercially for tannins, fuelwood, timber, gum, adhesives, pharmaceuticals, inks, confectionary, and other products. Selfincompatibility is considered an important outbreeding mechanism in Acacia, with many species being highly self-incompatible (Fleming et al 2007).

A total of 37,786 putative SNPs were identified in Acacia auriculiformis $\times$ Acacia mangium hybrids using next-generation transcriptome sequencing. Most SNPs were converted to successful assays which are not only important for linkage map construction, but are also very useful for hybrid discrimination and genetic diversity assessment of natural germplasms in the future (Wong et al 2012). Genes involved in lignin biosynthesis and secondary cell wall formation in Acacia hybrids were identified by sequencing transcriptomes of non-normalized cDNA libraries synthesized from the pooled young stem and inner bark tissues using paired-end libraries and a single lane of an Illumina GAll machine (Wong et al 2011). The role of microRNAs was demonstrated and characterized by acting as sequence-specific guides expressed during secondary wall biosynthesis in Acacia mangium. The involvement of six highly-conserved amgmiRNA families viz., amg-miR166, amg-miR172, amg-miR168, amg-miR159, amgmiR394 and amg-miR156 in secondary cell wall biosynthesis (Ong and Wickneswari $2011,2012)$ was reported. Williams et al (2015) reported the first cp genome of $A$. ligulata with $158 \mathrm{Kbp}$ size which comprised inverted repeats of 25,925 bp and single-copy 
regions of $88,576 \mathrm{bp}$ and $18,298 \mathrm{bp}$, and revealed clpP1 gene which is highly divergent and an essential part of $\mathrm{cp}$ genomes.

\section{xi. Casuarina equisetifolia (Casuarina)}

Casuarina equisetifolia L. (beefwood) is an evergreen, dioecious or monoecious tree, 6$35 \mathrm{~m}$ tall, with a finely branched crown. It belongs to the casuarinaceae family and originated from Australia, Bangladesh, Brunei, Cambodia, Fiji, Indonesia, Malaysia, New Zealand, Papua New Guinea, Philippines, Samoa, Solomon Islands, Thailand, Tonga, Vanuatu and Viet Nam. However, due to its fast-growing nature, it has been introduced to more than 60 countries and is now a common feature of the coastal landscape of most tropical and sub-tropical countries, where it is often naturalized. The species was introduced for firewood, beautification and other purposes to India, Pakistan, East, Central and West Africa, West Indies, Florida (USA) and the Gulf of Mexico. It is commercially planted under farm forestry, agroforestry or as windbreaks for poles, fuelwood, bioenergy, pulpwood and plywood purposes. It comprises nine pairs of chromosome $(2 n=18)$. The work on reproductive biology suggests that $C$. equisetifolia is self-compatible and that the breeding system should be classified as facultative xenogamy.

The molecular mechanism during Casuarina equisetifolia-Trichosporium vesiculosum was assessed and transcript profiling revealed the expression of resistance genes; cytochrome oxidase; trans membrane proteins; genes involved in programmed cell death like 26S proteasome and ubiquitin-activating enzyme; early nodulin gene, wound inducible metallocarboxy peptidase inhibitor, glucanase, metal binding protein and signal recognition particle (Ghosh Dasgupta et al 2013).

A class I chitinase (CeChi1) belonging to PR-3 family was cloned and characterized from the needle tissues of $C$. equisetifolia challenged with fungal elicitor. The CeChi1 open reading frame comprised 966 nucleotides harboring a cysteine-rich chitin-binding domain and lysozyme-like domain. Quantitative real-time PCR analyses at different time 
points showed up-regulation of the transcript during pathogen elicitation and salicylic acid signaling (Veluthakkal and Ghosh Dasgupta 2012). CeChi1 was ectopically expressed in tobacco and in vitro antifungal bioassay using the total proteins from leaves of transformed plantlets revealed the characteristic lysis of hyphal tips of pathogenic fungi including Trichosporium vesiculosum, Fusarium oxysporum and Rhizoctonia solani (Veluthakkal and Ghosh Dasgupta 2015).

The transcriptome of the developing secondary tissues (15 years old) of Casuarina equisetifolia sub sp. equisetifolia was sequenced, de novo assembled, annotated and mapped to functional pathways. A total of 26,985 transcripts were predicted and mapped to 31 pathways. Mining of the annotated data identified nine genes involved in the lignin biosynthesis pathway and relative expression of the transcripts in four tissues including scale-like leaves, needle-like brachlets, wood, and root were documented. The expression of $\mathrm{CeCCR} 1$ and $\mathrm{CeF} 5 \mathrm{H}$ were significantly high in wood tissues, while the maximum expression of CeHCT was documented in the stem. Additionally, CeTUBA and $\mathrm{CeH} 2 \mathrm{~A}$ were identified as the most stable reference transcript for normalization of qRT-PCR data in C. equisetifolia (Vikashini et al 2018). ISSR and FISSR markers were used for the genetic analysis of the six species of Allocasuarina, five species of Casuarina and 12 superior-performing selections of C. equisetifolia (Yasodha et al 2004). Further, Ghosh et al (2011) and Nicodemus et al (2011) reported the development of species diagnostic ISSR-SCAR markers for Casuarina equisetifolia and C. junghuhniana.

\section{xii. Santalum album (Sandalwood)}

Sandal (Santalum album L.), one of the most primitive, precious and useful plants species, belongs to the santaleaceae family. Botanically, there are 16 species in the genus Santalum and one of them is Santalum album - Indian Sandalwood which is widely exploited for its heartwood oil "santalol". Historically, the Western Ghats region is home to Indian sandalwood trees. The species is presently distributed in Australia, Indonesia, Malaysia, Africa and China. In traditional medicine, sandalwood oil has been used as an 
antiseptic and astringent. It has also been used to treat headaches, stomachaches, and urinary and genital disorders. It is widely used in perfumes and pharmaceuticals.

Studies have revealed that flowers of Santalum album are self-incompatible and are strictly adapted for cross pollination by insects. The cytological studies in sandal states $2 n=20$ and $2 n=40$ chromosomes numbers. Rani et al (2013) isolated the sequences encoding farnesyl diphosphate synthase and santalene synthase from sandalwood using suppression subtraction hybridization and 2D gel electrophoresis technology. Mahesh et al (2018) established a draft map of Santalum album with $221 \mathrm{Mbp}$ genome sizes and predicted 38,119 protein coding genes and $27.42 \%$ repetitive DNA elements. Proteomics revealed 72,325 unique peptides, which confirmed 10,076 predicted genes, while transcriptomic studies identified 53 novel proteins and 1,348 potential noncoding RNAs. Dasgupta et al (2019) have sequenced the $S$. album representing the natural population of Kerala and presented its draft genome with $286 \mathrm{Mbp}$ size containing 37,500 genes, including 30 genes from the terpene synthase gene family, and predicted a total of 1,191,838 (0.42\%) SNPs and 98,312 (0.034\%) InDels. In addition, $147.25 \mathrm{Kbp}$ chloroplast genome has been sequenced. Yang et al (2020) determined the first complete $\mathrm{cp}$ genome sequence of $S$. album using Illumina HiSeq pair-end sequencing data and reported 144,101 bp size containing 123 genes, including 80 protein-coding genes, 8 rRNA genes, and 35 tRNA genes. Mohammad et al (2012) evaluated the transferability of Santalum austrocaledonicum and Santalum insulare SSRs to Santalum album to examine the molecular diversity of 20 accessions from two diverse localities comprising germplasm of Madhya Pradesh and Karnataka.

\section{xiii. Litsea glutinosa (Indian laurel)}

Litsea glutinosa (Lour.) C.B. Rob. is an evergreen species of the tropical rainforest, and belongs to the family, Lauraceae. It is commonly known as bollygum, bolly beech, brown beech or Indian laurel, and grows 3-15 m tall in height. It is native to India, South China, Malaysia, Philippines, Australia and the western Pacific islands. The species was commercially introduced to La Réunion, Mauritius and Mayotte, and is principally used 
as a binding agent in the incense-stick industry (Agarbatti), in tablet formulations and as plaster for fractured limbs. The wood is used for making agricultural tools, and the root fibre for making ropes and paper pulp (Arunachalam et al 2019). Litsea glutinosa is traditionally used to treat various human ailments and diseases.

It is a dioecious plant comprising separate staminate and pistillate in flowers. The florets display myophilous pollination syndrome and are pollinated by flies, as well as other insects. The genetic diversity and population structure of Litsea glutinosa in Central India using ISSR markers was first assessed by Mohammad et al (2018). The species is one of the fastest dwindling forest species in central India, and is represented by highly fragmented populations that have been drastically reduced in the last 40 years; its extraction has been banned by the government.

The sampled populations harbored a high level of genetic diversity (mean $h=0.294$ and $I=0.424)$ that was partitioned more within populations $(73 \%)$ than between populations (27\%). Bayesian structure analysis revealed the existence of four admixed genetic pools in L. glutinosa. The dioecious nature of the species advocates in-situ conservation as the most suitable approach - Chhindwara, Jagdalpur, Balaghat and Jabalpur populations are appropriate.

\section{xiv. Pongamia pinnata (Karanj)}

Pongamia pinnata L. Pierre is a multipurpose versatile Leguminosae (papilionaceae) member and native to Bangladesh, India, Myanmar, Nepal and Thailand. It has been introduced to parts of Australia, New Zealand, China and the USA, as well as other humid tropical regions of the world. The natural distribution of the species is along coasts and river banks in India and Myanmar. It is mostly used for biodiesel, as fodder for cattle and goats, blended with nitrogenous fertilizers, and as fuelwood. The timber is moderately strong and used for cabinet making, cartwheels, posts, agricultural implements, tool handles and combs (Chaturvedi et al 2017). 
Bees and wasps promote cross pollination in pongamia. The number of chromosomes are $2 n=22$. However, to date, there has been little genomic research aimed at exploitation of the biotechnological potential of this species. Choudhury et al (2013) studied the genome size of $P$. pinnata which was estimated by flow cytometry to two standards (Zea mays and Pisum sativum), and compared with that of in vitro-raised plants (nodal segment, in vitro-rooted plantlets and acclimatized in vitro plants). Jin et al (2019) identified 236 conserved miRNAs within 49 families and 143 novel miRNAs via deep sequencing of pongamia seeds sampled at three developmental phases. For these miRNAs, 1,327 target genes were computationally predicted. Furthermore, 115 differentially expressed miRNAs (DEmiRs) between successive developmental phases were sorted out. The DEmiR-targeted genes were preferentially enriched in the functional categories associated with DNA damage repair and photosynthesis.

Many nuclear genes associated with oil biosynthesis and nodulation in Pongamia have been characterized. Kazakoff (2012) assembled and annotated pongamia chloroplast and mitochondrial genomes; the cpDNA contains 77 unique protein-coding genes and is almost $60 \%$ gene-dense. Comparison of Pongamia organelle genome with other legumes revealed many similarities among species (Biswas et al 2013). It contains a 50 $\mathrm{Kbp}$ inversion common to other legumes, as well as a novel $6.5 \mathrm{Kbp}$ inversion that is responsible for the non-disruptive, re-orientation of five protein-coding genes. Additionally, two copies of an inverted repeat firmly place the species outside the subclade of the Fabaceae. The Pongamia and L. japonicus mtDNA contain just 33 and 31 unique protein-coding genes, respectively, and like other angiosperm mtDNA, have expanded intergenic and multiple repeat regions. Through comparative analysis of $P$. pinnata L. japonicus and Vigna radiata, the average synonymous and non-synonymous divergence was measured in protein-coding genes of mitochondrial ( $1.59 \%$ and $2.40 \%$, respectively) and chloroplast ( $8.37 \%$ and $8.99 \%$, respectively) protein-coding genes. The utility of the organellar genome sequences was unveiled by mapping transcriptomic data to identify up- and down-regulated stress-responsive gene candidates and confirm in silico predicted RNA editing sites. 
Sreeharsha et al (2016) performed the whole transcriptome analysis of pongamia through the Illumina NextSeq platform and generated 2.8 Gbp of paired-end sequence reads. The de novo assembly of raw reads generated 40,000 contigs and 35,000 transcripts, representing leaf, flower and seed unigenes. Spatial and temporal expression profiles of photoperiod and floral homeotic genes in pongamia, identified GIGANTEA (GI) CONSTANS (CO) - FLOWERING LOCUS T (FT) as an active signal cascade for floral initiation. Besides, four prominent stages of seed development were selected in a high yielding pongamia accession (TOIL 1) to follow the temporal expression patterns of key fatty acid biosynthetic genes involved in lipid biosynthesis and accumulation. They provide insights into an array of molecular events, from flowering to seed maturity, which will provide a substantial basis for modulation of fatty acid composition and enhancing oil yields which could serve as a potential feedstock for biofuel production.

Jiang et al (2012) studied the variation for seed mass, oil content and oil composition. To evaluate genetic diversity and to lay the basis for a molecular breeding approach, we developed second-generation sequencing (2GS)-derived ISSR markers (Pongamia InterSimple Sequence Repeats; PISSR). The special feature of PISSRs is that the number of nucleotide repeats and the 5' and 3' nucleotide extensions were not arbitrarily chosen, but were based on pongamia genomic sequences obtained from an NGS (Illumina $($ ) database. They demonstrated: 1) an abundance of nucleotide core repeats in the genome, 2) large genetic and phenotypic diversity among randomly sampled pongamia trees, 3) restricted diversity in progeny derived from a single mature tree; 4) stability of PISSR markers in clones, and 5) genomic DNA sequences within PISSR markers. The genetic diversity in 37 wild species of $P$. pinnata has been assessed using 18 RAPD and 23 SRAP primers which generated 150 polymorphic bands (96.8\% polymorphism) and 122 polymorphic (84.1\% polymorphism) bands. The mean PIC for both the markers was 0.77 and 0.68 . This, along with PCA, confirmed the existence of genetic diversity among the accessions. 


\section{Xv. Morus species}

The scientific name of mulberry is Morus spp., a genus belonging to the Moraceae family of the Urticales sub-class. There are about 68 species of the genus Morus, and majority of them occur in Asia (Datta 2000). In China, there are over a thousand varieties under cultivation. They originated from four main species, the White mulberry (Morus alba), the Lu mulberry (M. multicaulis), the Mountain mulberry (M. bombycis) and the Guangdong mulberry ( $M$. atropurpurea) (Yongkang 2000). Mulberry, a perennial deciduous plant is reported to have originated from China, the primary centre of the plant origin, apart from the Indian species namely, $M$. indica, $M$. alba, $M$. serrata and $M$. laevigata, which are considered indigenous to India. The species is utilized for silk production, fodder, fuelwood and food. The Central Silk Board-Central Sericulture Research and Training Institute's Mysore campus possesses 350 mulberry accessions (CSRTI 2019) while Pampore, Srinagar campus possesses 47 temperate origin mulberry accessions including 16 indigenous and 31 exotic (Saini et al 2018). Morus consists of diploid chromosome number $(2 \mathrm{n}=28)$ and monoecious flowers. The mode of pollination is through wind, i.e., anemophilous pollination.

In Morus sp. identification of drought-regulated genes and the generation of a large number of ESTs was reported by Gulyani and Khurana (2011). Thumilan et al 2013 identified and characterized 222 genomic and 136 genic SSRs from genomic clones and ESTs in this species. Besides, Krishnan et al (2014) reported around 217,312 SSRs from genome sequence and 961 SSRs from EST sequences of M. notabilis. However, Saeed et al (2016) have generated 87.0 and $80.3 \mathrm{Mbp}$ of transcriptomic data from M. laevigata and $M$. serrata, assembled them into 95,181 and 85,269 transcripts, respectively, and identified 24,049 SSRs, 1,201,326 SNPs and 67,875 InDels. Further, 206 EST-driven SSRs has been developed and validated from transcriptomic data of drought-tolerant mulberry cv. Dudia white (Thumilan et al 2016). Recently, 248 genomic-SSR and 490 genic-SSR (EST-SSR) primers were designed and used in marker-assisted breeding programmes (Sarkar et al 2017). 


\section{xvi. Boswellia sacra (Frankincense)}

Boswellia sacra is commonly known as frankincense or olibanum-tree. It belongs to the Burseraceae family and is considered an economically important species of the genus Boswellia. The species is endemic to Ethiopia, northern Somalia, south-western Oman and southern Yemen. It is considered an economically important species, and is a good source of high quality frankincense and bioactive compounds. Medicinally it can be used as an analgesic, hepato-protective, antioxidant, diuretic, anti-coagulant, and to treat tumors and skin disorders (Al-Harrass et al 2018). The species has chromosome numbers of $2 n=22$ and is open-pollinated mainly through bees and wind. It is self-incompatible and the selfed pollen tubes are inhibited soon after their entry into the stigma. The chloroplast genome of Boswellia sacra has been sequenced and the size is about $160 \mathrm{Kbp}$ with $37.61 \%$ GC content (Khan et al 2017). Further, De novo assembly and annotation showed the presence of 114 unique genes with 83 protein-coding regions. Based on this, a phylogenetic relationship was assessed with Azadirachta indica and Citrus sinensis.

\section{xvii. Moringa oleifera (Drumstick)}

Moringa oleifera Lam. belongs to the family Moringaceae. It is a single genus family comprising 13 species distributed in India, Kenya, northeastern and southwestern Africa, Arabia and Madagascar (Saini 2015). M. oleifera is native to the sub-Himalayan Mountains of northern India and cultivated throughout the world in tropical and subtropical regions (Leone et al 2015). It has been considered as a super food, and miracle tree as every part of it is filled with minerals, vitamins and antioxidants, and has the

potential to treat over 300 diseases. Its tender roots are used to make pickle, especially in the Bundelkhand region of India. Its seed oil is equivalent in quality to olive oil, and has the potential to be used as biodiesel. The chromosomes number in Moringa is $2 n=28$. Moringa flowers are dichogamous and follow xenogamy and cross-pollination mainly through bees and other insects. Moringa leaves, flowers, and pods are commonly used as food due to its richness in vitamins and ions. 
Pasha et al (2020) have developed a bioinformatics pipeline to assemble transcriptome, along with the previously published $M$. oleifera genome, to predict 17,148 gene models. Few candidate genes related to the biosynthesis of secondary metabolites, vitamins and ion transporters were identified. Expressions were further confirmed by real-time quantitative PCR experiments for a few promising leads. Quantitative estimation of metabolites, as well as elemental analysis, was also carried out to support our observations. Enzymes in the biosynthesis of vitamins and metabolites like quercetin and kaempferol are highly expressed in leaves, flowers and seeds. The expression of ion transporters and calcium storage proteins was observed in roots and leaves. In general, leaves retained the highest amounts of small molecules of interest. This study showed that the leaves contain 30 times more iron and 100 times more calcium than spinach. Indeed, iron, zinc and magnesium transporters were found to be highly abundant in the roots and stem. A total of 36 candidate genes were tracked in this study from all five tissues. These include the synthesizing enzymes for compounds (flavonoids, terpenoids, vitamins and alkaloids like moringine) and transporters of minerals. Among these, the bioactive compounds of medicinal value such as quercetin (effective in metabolic disorders) and its synthesizing enzymes are observed more in leaves and flowers. Kaempferol (effective as anti-cancer agent) was observed to be abundant in the flowers.

Tian et al (2015) report a high-quality draft genome sequence of $M$. oleifera. This assembly represents $91.78 \%$ of the estimated genome size and contains 19,465 proteincoding genes. Comparative genomic analysis between $M$. oleifera and related woody plant genomes helps clarify the general evolution of this species, while the identification of several species-specific gene families and positively selected genes in M. oleifera may help identify genes related to the species' high protein content, fast-growth, heat and stress tolerance. Liu et al (2019) reported the complete chloroplast genome sequence of M. oleifera for the very first time (accession number of MH778650), and it was also the first reported chloroplast genome of Moringaceae. The chloroplast genome is 160,599 bp long and includes 113 genes. Its LSC, SSC and IR regions are 88,933, 19,482 and 
26,092 bp long, respectively. Phylogenetic tree analysis revealed that $M$. oleifera was clustered with other Moringaceae species with $100 \%$ bootstrap values.

\section{xviii. Albizia procera (White siris)}

Albizia genus comprises over 160 species in the sub-family Mimosoideae of the family Fabaceae. The genus is pantropical, occurring in Asia, Africa, Madagascar, America and Australia, but is more common in the Old World tropics. It is a valuable timber and is used in general construction (house posts, beams, scantlings, planks, boards), carriage and carts, lorry and bus bodies, agricultural implements, tool handles, packing cases and crates (Sivakrishnan and Swamivelmanickam 2019). The species is self-pollinated through insects and consists of $2 n=26$ numbers of chromosomes. Aparajita et al (2010) used 12 AFLP primers to study the genetic diversity of Albizia species. Mohammad et al (2016) used RAPD and ISSR markers to authenticate the true-to-type nature of the in vitro-raised plantlets of Albizia procera. Aparajita et al (2016) studied the structure of 102 individuals representing six natural populations of wider range using ISSR markers and observed $34.16 \%$ and $65.84 \%$ variances between and within the population, respectively.

\section{xix. Tamarindus indica (Tamarind)}

Tamarindus indica L. (Leguminosae: Caesalpinioideae), is an example of an economically important but little studied tropical fruit tree. The seeds in its indehiscent pods are enveloped by dark brown pulp with a pleasantly sweet and acid flavor, much appreciated in condiments and used as juice. Breeding system and pollination biology of the semi-domesticated tamarind tree has been examined (Diallo et al 2008). They observed that open- and cross-pollination give better quantitative seed than selfpollination. It is a diploid species with chromosome number of $2 n=24$ as quoted by Gunasena and Hughes (2000). A high rate of seed abortion in the self-pollination system has been observed. Results revealed that there is a post-zygotic self-incompatibility and other factors, not related to the pollination system, intervened in seed development after fertilization of ovules. Genetic diversity was also assessed by RAPD markers (Diallo et al 
2007). In Vivo Biochemical and Gene expression analyses of the antioxidant activities and hypo-cholesterolaemic properties of Tamarindus indica fruit pulp extract were also analyzed.

\section{xx. $\quad$ Ailanthus excelsa (Tree of heaven)}

Ailanthus excelsa Roxb. is a member of the Simaroubaceae family and is commonly known as Ardu, Mahaneem or tree of heaven. It is considered native to the Indian Peninsula and distributed throughout the tropical and sub-tropical regions of India. The tree is multi-purpose and is used in production of match splints, packing cases, fishing floats and sword sheaths. It can also be used as fodder. The species favours xenogamous pollination. The wood transcriptome of a 22-month old tree was sequenced and de novo assembled. A total of 48,493 transcripts were predicted with N50 of 1,606 bp. The chloroplast genome was re-constructed and 160,804 bp genome assembled, encoding 116 genes. Phylogenetic analysis using the complete chloroplast genome revealed that members of Simaroubaceae form sister clade with a 95\% bootstrap support to Rutaceae family (Saina et al 2018). Mining for microsatellite repeats predicted the presence of 5,501 repeats in the wood transcriptome. This study presents the first genomic resource in the genus Ailanthus. The information generated can be used for subsequent research in diversity assessment, population structure analysis, and accelerated breeding targeting the improvement of wood property traits in this species (unpublished data from IFGTB Coimbatore, India).

\section{xxi. Korthalsia laciniosa (Rotan Dahan)}

Korthalsia laciniosa is commonly known as Rotan dahan. It is a climbing, evergreen shrub, producing a cluster of slender; woody stems around $20-30 \mathrm{~mm}$ in diameter. It is grown in Southeastern Asia - Thailand, Cambodia, Laos, Viet Nam, Malaysia, Indonesia and the Philippines. The durable canes are highly sought after at village level, and used to make baskets, for weaving, etc. The cytological study reveals that the species has $2 n=32$ chromosomes. Mode of pollination is through bees. Draft genome sequence of Korthalsia laciniosa (Griff.) Mart.: a clustering rattan was generated and the reads 
assembled into 243,005 scaffolds with $N 50$ of $23,613 \mathrm{bp}$. A total of 21,833 genes were predicted and assigned to 6,627 gene families. Taxonomic distribution based on homology search with monocots revealed the highest similarity with Elaeis guineensis. Cataloging of functional pathways mapped the predicted genes to 391 pathways. Additionally, the draft genome was mined for microsatellite repeats and 267,240 SSRs were predicted (unpublished data from IFGTB Coimbatore, India).

\section{xxii. Annona squamosa (Custard Apple)}

Annona squamosa L., (custard apple) belongs to the Annonnaceae family. It is a popular fruit tree which originated in America and is a widely cultivated species both within its native range and in tropical regions around the world. This plant is also known as sugar apple or sweetsop and has many other regional names such as custard apple (India), anon (Portuguese), and noi-na (Thailand). The fruits are consumed widely and the tree is also a source of medicinal and industrial products. The fruits contain vitamin $C$ and minerals such as calcium, phosphorous and potassium. They are also an excellent source of energy, being rich in carbohydrates. Its chromosome number is $2 n=14,16$ and flowers are protogynous, pollinated mainly by wind and honeybees. Custard apple de novo assembly and characterization of transcriptomes of early-stage fruit from two genotypes of Annona squamosa L. with contrast in seed numbers through massive pyrosequencing were reported by Gupta et al (2015). The data reported here is the first source of genome-wide differential transcriptome sequence in two genotypes of $A$. squamosa and identifies several candidate genes related to seed development. Liu et al (2017) studied the comparative transcriptomic analyses of normal and malformed flowers in sugar apple (Annona squamosa) to identify the differential expressed genes between normal and malformed flowers. In this study, a comprehensive perspective on the differences between normal and malformed flowers of sugar apple, was prepared independently by Illumina sequencing. The data generated a total of $70,189,896$ reads that were integrated and assembled into 55,097 unigenes with a mean length of $783 \mathrm{bp}$. A large number of differentially expressed genes (DEGs) were identified. Among these DEGs, 701 flower development-associated transcript factor encoding genes were 
included. Furthermore, a large number of flowering- and hormone-related DEGs were also identified, and most of these genes were down-regulated expressed in the malformation flowers. The expression levels of 15 selected genes were validated using quantitative-PCR. The contents of several endogenous hormones were measured. The malformed flowers displayed lower endogenous hormone levels compared to the normal flowers. Anuragi et al. (2016) suggested the existence of significant genetic diversity among 20 Annona genotypes representing five different species of Annonaceae based on 11 RAPD and 12 SSRs markers which yielded 152 bands (80.01\% polymorphism), 0.89 PIC for RAPD, 39 amplicons (93.05\% polymorphism) and 0.339 PIC for SSR primers.

\section{xxiii. Syzygium cumini (Jamun)}

The family of Myrtaceae consists of about 121 genera with 3800-5800 species of shrubs and trees mainly distributed in tropical and sub-tropical regions of the world (Stefanello et al 2011). The genus Syzygium, a leading member of this family, embrace 1,100 species with deserving attention to Syzygium cumini (L.), an important indigenous fruit tree in India. It is a good source of iron apart from being the source of minerals, sugars and other phytochemicals. S. cumini is diploid, consists of $2 n=66$ chromosomes, and is open-pollinated by wind and honey bees. Only few genomics-related studies have been conducted in the Myrtaceae family so far. The 23 wild jamun genotypes comprising Andaman and Nicobar Islands and the mainland were analyzed for genetic diversity with the help of 30 ISSR and 20 RAPD primers (Shakya, 2010). Asif et al. (2013) estimated that the size of the IR region in S. cumini cpDNA is 26,392 bp with 20 genes. They also compared S. cumini cpDNA sequence with previously reported partial sequences of $S$. cumini as presented in GenBank and found a range of sequence polymorphisms.

\section{xxiv. Commiphora wightii (Guggul)}

Commiphora wightii [(Arnot) Bhandari] is a medicinal shrub of the family Burseraceae. It is xerophytic in nature and grows naturally in the arid and rocky zones of India, that is, Gujarat, Karnataka, Madhya Pradesh and Rajasthan, and also in Pakistan. Guggul 
consists of $2 n=26$ chromosomes. It is valued for its medicinal oleo-resin gum rich in guggulsterone and reproduces through sporophytic apomixes. Further, it is dioecious or polygamous, apomictic and pollinated by birds. The main economic product from this tree is gum-resin. The Central Institute of Medicinal and Aromatic Plants (CIMAP), Lucknow has developed a good oleo-gum-resin-yielding cultivar called 'marusudha'. Guggul is enlisted under the 'data deficient' category in the IUCN Red Data Book (http://www.iucnredlist.org/details/31231/0). Geetha et al (2013) carried out a comprehensive investigation of guggul reproduction to understand histology, controlled pollination, flow cytometry and conducted RAPD analyses of progeny to assess the occurrence and extent of sexual reproduction. They reported obligate sexual female plant and documented a unique pollen-pistil incompatibility that prevents all but one pollen tube growth into the style to effect fertilization. Harish et al (2014) estimated the genetic diversity to ascertain the conservation priorities and strategies, and reported a total of 155 amplified products using RAPD and ISSR primers with overall $86.72 \%$ polymorphism across 45 individuals representing eight populations. Mantel's test revealed no correlation between genetic and geographical distances of populations $\left(R^{2}=0.122\right)$.

\section{xxv. Prosopis cineraria (Khejri)}

Prosopis cineraria (L.) Druce, widely known as Khejri or the king of desert, belongs to the sub-family Mimosoideae of Leguminosae family, and originated from Afghanistan, India, Iran, Pakistan and Sri Lanka. It is commonly found in the Thar Desert of India and Pakistan. P. cineraria pods are used as a vegetable, both in dried and green forms, in many parts of the Thar Desert. The tree provides fodder, fuelwood, pods and timber. The species is mainly planted for sand dune stabilization and reclamation. It also fixes atmospheric nitrogen (Kreethika et al 2015). The species consists of $2 n=28$ chromosomes and non-synchronous flowering to facilitate cross-pollination. Sharma et al (2011) assessed genetic diversity within and between Prosopis cineraria accessions collected from different districts of Rajasthan (India) and generated a total of 83 bands from eight ISSR and five DAMD primers with $95.18 \%$ polymorphism. 
Nei's gene diversity (h) was $0.185-0.301$, while Shannon's information index (I) values ranged from 0.253 to 0.438 , demonstrating the higher genetic variation within the population. Sivalingam et al (2016) developed markers for varietal identification among Thar Shobha and other Prosopis cineraria resources in which 80 RAPD primers were tested. Out of these, nine were polymorphic between 'Thar Shoba' and trees in a natural population of khejri. Phenetic analysis revealed that 'Thar Shoba' formed a separate cluster from the natural population with similarity coefficients of 0.57-0.78. The 10-mer primers OPBE05, OPBA13, OPA12, and OPA14 were each found to differentiate 'Thar Shoba' from the natural population by one amplicon. Transcriptome analysis of $P$. cineraria using RNA_Seq technology was first analyzed by Rai et al (2017). The study concluded that about 142,711 unigenes assembled de novo from leaf transcriptome and 60,583 CDS predicted from unigenes. However, 57,249 CDS were annotated by blast searches against public database and 950 CDS had a high expression level of $>100$ rpkm.

\section{xxvi. Sapindus emarginatus (Soap-nut tree)}

Sapindus emarginatus Wahl, commonly known as soap nut tree or reetha, belongs to the sapindaceae family. It is andromonoecious and has both bisexual and male flowers on the same plant. This species is native to south India, mainly around the peninsular region, and is globally distributed in Sri Lanka and Myanmar. The fruits are used to cure asthma, cholera and diarrhea, and to ease delivery during childbirth. The fruit paste is applied in scorpion stings, snakebites and used as a leech repellent.

Sapindus emarginatus is cross-pollinated by a wide variety of insects; the species has a chromosome number of $2 n=30$. Mahar et al (2011) studied the genetic variability within and between 41 accessions representing five populations using RAPD, DAMD and ISSR primers, and observed $82.32 \%$ polymorphism across all the accessions of Sapindus emarginatus. AMOVA revealed $72 \%$ variation among individuals of populations followed by $16 \%$ among regions and $12 \%$ among populations. Mantel's test revealed a highly 
significant correlation between cumulative vs RAPD, and showed the maximum (0.93) correlation coefficient, followed by cumulative vs ISSR (0.78) and cumulative vs DAMD (0.91), respectively.

\section{xxvii. Jatropha curcas (Jatropha)}

Jatropha curcas L. belongs to the Euphorbiaceae family and is traded as jatropha or physic nut. It originated from Belize, Costa Rica, El Salvador, Guatemala, Honduras, Mexico, Nicaragua and Panama. From the Caribbean, Jatropha curcas was probably distributed by Portuguese seafarers via the Cape Verde Islands and former Portuguese Guinea (now Guinea Bissau) to other countries in Africa and Asia. It is mainly used for biodiesel, feedstock, organic manure and live hedges. The genus Jatropha is a diploid with a chromosome number of $2 n=22$. It comprises about 175 species worldwide. In India, 12 species are found scattered in various states. The species is monoecious, with male and female flowers on the same plant (Chaturvedi et al 2017). Jatropha is a crosspollinated species and is mainly pollinated by insects.

Kancharla et al (2019) have generated the hybrid de novo genome assembly with 265.7 Mbp in J. curcas using Illumina and PacBio sequencing technologies. Besides, they identified three minor QTLs for Jatropha Mosaic Virus (JMV) resistance in $F_{2}$ population of a resistant and susceptible crosses using 207 polymorphic SSR markers. Ha et al (2019) reported $\sim 339 \mathrm{Mbp}$ draft whole-genome sequence in Chai Nat variety using both the PacBio and Illumina sequencing platforms and identified differentially expressed genes relevant to the biosynthesis of lipids and toxic compounds during seed development. Tian et al. (2017) sequenced the transcriptome and developed a large number of microsatellite and SNP markers from the transcriptome sequences to facilitate the jatropha genetic improvement programme. Wang et al (2018) performed genomewide identification and transcriptional expression analysis and identified 12 JcMAPKs, 5 JcMAPKKs, and 65 JcMAPKKKs gene families which are fundamental signal transduction modules for controlling cell division, hormone signaling and overall growth and are activated under a variety of biotic and abiotic stresses. Kole et al (2015a) studied 
the genetic variability and relationship among 182 accessions of $J$. curcas collected from 19 Indian states. 30 RAPD markers generated 254 polymorphic bands (96.82\%) with average PIC of 0.791 . All this confirmed a high level of genetic variation among the accessions.

\section{xxviii. Mangifera indica (Mango)}

Mango (Mangifera indica L.) is an evergreen fruit tree belonging to order Sapindales of the family Anacardiaceae. It is known as the king of fruits due to its cultural value and taste, large production volume, and diverse end usage. However, mango breeding is challenging due to the long juvenile phase, high heterozygosity and heavy fruit drops. Flowers are either male (staminate) or hermaphroditic, containing both stamens and carpels. Mango has self-, cross-pollination, self-incompatibility and self-sterility systems; however, some cultivars are either semi-compatible or fully compatible. Wind is important in mango pollination. It has 20 pairs of chromosomes $(2 n=40)$ with an estimated genome size of $439 \mathrm{Mbp}$. A major limiting factor for mango improvement has been the paucity of genomic resources. Total $44.8 \mathrm{Gbp}$ of genomic sequence (102x coverage) was generated using PacBio platform. The genome was assembled and polished using FALCON and Quiver software, respectively. The resulting 9,500 contigs (401 Mbp) were arranged into 4,312 scaffolds (403 Mpb), covering $91.8 \%$ of the genome with the largest scaffold of $2.1 \mathrm{Mbp}$ and $\mathrm{N} 50$ of $282 \mathrm{Kbp}$. Over $80 \%$ of the scaffolds were anchored to 20 mango chromosomes with 6,242 markers of a recently published high density genetic map of 6,594 markers ( $94.66 \%$ coverage). A total of 53,018 genes were predicted, annotated and manually curated.

Further, 168,484 SSRs were identified, including 30,821 Type 1 and 12,855 highly variable SSR. We also identified 5.2 million high-quality SNPs in 19,656 single copy genes by re-sequencing 24 diverse mango cultivars and developed 80K SNP chip. Mango showed the highest similarity with Citrus sinensis among the published fruit genomes. The reference genome would fast track mango varietal improvement for stress tolerance, higher productivity, and superior quality. The genome sequence of mango 
variety Amrapali was deposited in the NCBI GenBank public repository in 2015 and upgraded in 2017 (Acc no. LMWC00000001), and now maternal and paternal phaseseparated reference genome assemblies of the two parental lines of Amrapali, namely Dashehari and Neelam have been submitted to NCBI. Recently, genome sequences of two more varieties were assembled based on PacBio SMRT sequencing ( $\mathrm{Li}$ et al 2020; Wang et al 2020).

\section{xxix. Quercus leucotrichophora (Banj oak)}

Among the broad leaf species, oaks (Quercus spp.) are important, dominant vascular plants of the Himalayas, ranging from the sub-tropical to the sub-alpine zones. Banj oak (Quercus leucotrichophora A. Camus) is the most common broadleaf tree in the midelevation central Himalaya in India. It is the most preferred tree species in the temperate region, mainly used for fodder, fuel and small timber. Q. leucotrichophora forms an extensive belt along the middle elevation (1200-2200 m) facing excessive pressure for existence. The replacement of oak by pine has become a common and ever-increasing phenomenon in this region. Basic chromosome number $\mathrm{x}=8$ with various levels of ploidy, monoecious (individual flowers are either male or female, but both sexes can be found on the same plant) and is pollinated by wind. Very few studies have been reported on this species. Research has been confined to genetic diversity analysis with the help of random primers. Four populations collected from Jhungi Suket, Taradevi Shimla, Bhatwari-Taknor Range and Nohra-Shimla were studied using RAPD markers out of 10 primers, five polymorphic markers were selected which gave total mean diversity $(\mathrm{Ht})$ value of 0.2253 (Saha 2018).

\section{xxx. Cedrus deodara (Himalayan cedar)}

Cedrus deodara (Roxb. ex D. Don) G. Don (deodar or Himalayan cedar) also known as Indian cedar is one of the most important temperate timber species of the Western Himalayas and is considered one of the endangered conifer species in this region. It grows right from Afghanistan to Garhwal at an elevation of 1200-3050 m. The strongest of Indian coniferous woods, it is used for door and window frames, furniture packing- 
cases, beams, masts, spars and shingles, and also for bridges and railway sleepers. Wood yields an oleoresin and dark coloured oil used for ulcers and skin diseases. It is a monoecious, anemophilous species where male and female cones typically occur on the same tree but on separate branches. RAPD markers were used to study genetic variation in three natural populations of western Himalaya using 10 primers. The study indicated that $C$. deodara populations maintained moderate level of genetic diversity (mean $\mathrm{Ht}=0.233$ ) with more variation among the populations when compared to within population (Rai 2020). Karyotype investigation showed a simple monosomatic haploid level in the megagametophyte, as compared to the diploid level of the corresponding embryo. Cytogenetic studies showed a diploid chromosome number of $2 n=24$ in 11 populations sampled over the four species including Cedrus deodara. Eight GC-rich chromomycin A3 bands were observed in Cedrus deodara chromosomes (DagherKharrat 2001). Complete chloroplast genome of $53,775 \mathrm{~kb}$ is available in the public domain (Lin et al 2010).

\section{xxxi. Myrica esculenta (Chinese Bayberry)}

The Myrica genus is a large group comprising more than 97 species in the Myricaceae family. Among several species, Myrica esculenta Buch.-Ham. ex. D. Don dubbed 'Hairy Bayberry' or Chinese Bayberry, is also widely known as Kaiphal or Kataphala in the Indian sub-continent (Kabra et al 2019). It is a popular medicinal plant distributed in the sub-tropical Himalayas. It is also found in the sub-tropical and temperate zones of China, Taiwan, Japan, Western Highland of Cameroon, North America, South Africa, Australia, Brazil, Ethiopia and Nepal. All the parts of the M. esculenta plant have huge nutritional and therapeutic importance. Fruits are used for syrups, jams, pickles and in the preparation of refreshing drinks (Makdoh et al 2014). Basic chromosome number throughout the family is eight, with various levels of ploidy. The dioecious flowers are cross pollinated mainly through wind. This tree is well recognized in ayurvedic pharmacopeia and is widely used as traditional medicine to treat several ailments such as asthma, cough, chronic bronchitis, ulcers, inflammation, anemia, fever, diarrhea, and ear, nose and throat disorders. Recent upsurge in M. esculenta use and demand has led 
to illicit harvesting, thus pushing the plant to the brink of extinction. A 158-simple sequence repeat (SSR) markers have been developed by surveying of whole genome shotgun data (Jiao et al 2012). Sharma et al (2020) carried out DNA barcoding of Myrica esculenta for its molecular identification done through sequence analysis with three barcode loci - rbcL, matK and ITS genes. The nucleotide sequence of internal transcribed spacers (ITS2), chloroplast maturase kinase gene (matK) and rbcL have determined a close relationship among 12 other species of Myrica.

\section{xxxii. Taxus wallichiana (Himalayan yew)}

Taxus wallichiana Zucc. (Taxaceae yew family) is an evergreen tree which is mostly distributed in the temperate zone of the Northern Hemisphere, extending into the tropics and south of the Equator into Malaysia. In Asia, T. wallichiana Zuccarini (Himalayan Yew) is mostly distributed in the Himalayas stretching into Afghanistan, Bhutan, China, India, Indonesia, Malaysia, Myanmar, Nepal, Pakistan, the Philippines and Viet Nam. In the Indian Himalayan region, occurrence of the species has been reported in the states of Arunachal Pradesh, Himachal Pradesh, Uttarakhand, Jammu and Kashmir, Manipur, Meghalaya, Nagaland, Sikkim and West Bengal. It is the only Taxus species occurring in India. The yew has important economic value and has thus been subjected to severe exploitation. Moreover, as compared to other species, yew has some congenital deficiency such as insufficient seedlings, weak competitiveness and rigid habitat requirements (Ru et al 2006). Taxol is one of the most potent and effective anti-cancer drugs and is originally isolated from Taxus species. It has $2 n=24$ chromosomes and follows cross pollination.

A combination of transect study, population genetic analyses based on chloroplast DNA sequences and nuclear microsatellite data, and ecological modelling used to study patterns of genetic variation, levels of diversity and structure in the endangered allopatrically distributed Taxus contorta, $T$. mairei and $T$. wallichiana was undertaken in the highly fragmented and degraded habitats of the Himalayas. Results showed low genetic diversity and high inbreeding (Poudel et al 2014). Transcriptome sequencing of 
Taxus wallichiana var. Mairei (high taxol content Jinxishan variety) revealed that high expressions of the genes taxadienol acetyltransferase (TAT), taxadiene 5-alpha hydroxylase $(T 5 H)$, 5-alpha-taxadienol-10-beta-hydroxylase $(\mathrm{T} 10 \mathrm{H})$, and 2-debenzoyl7,13-diacetylbaccatin III-2-O-benzoyl-transferase (DBBT), which catalyze a series of key acetylation and hydroxylation steps, are the main cause of high taxol content in Jinxishan (Wang et al 2019).

\section{xxxiii. Dendrocalamus hamiltonii (Hamilton's bamboo)}

Dendrocalamus hamiltonii is an economically important bamboo species used to produce fermented bamboo shoots which is a popular traditional food item of the northeast state of India. This species has been experiencing population depletion due to heavy extraction from natural forests. Genetic variability of this bamboo species in Chandel and Imphal-East (commercial production districts) was assessed using AFLP molecular markers. Principal coordinate analysis based on the AFLP data clearly separated the populations according to their genetic diversity and antioxidant activity. Association of DNA markers with antioxidant activities and total cyanide content was also found (Waikhom et al 2012). Meena et al (2019) used nuclear simple sequence repeats (nSSRs) to study the genetic diversity and population genetic structure of 19 natural stands of $D$. hamiltonii distributed across the northeast Himalayas. Transcriptome analysis of rhizome and shoot during the major vegetative developmental transitions of $D$. hamiltonii is performed to dissect factors governing growth. It signifies the role of environmental cues, predominantly rainfall, decreasing day length and high humidity for activating dormant buds to produce new shoot, possibly through complex molecular interactions among phosphatidylinositol, calcium signaling pathways, phytohormones, circadian rhythm and humidity responses (Bhandawat et al 2017).

\section{xxxiv. Citrus species}

Citrus is a large genus that includes several cultivated species and is grown in more than 100 countries. The most widely cultivated citrus species under domestication and selective breeding include sweet orange (Citrus sinensis), mandarin (Citrus reticulata), pummelo (Citrus grandis), 
grapefruit (Citrus paradisi) and lemon (Citrus limon) (Li et al 2020). Citrus fruits possess unique botanical features, i.e., nucellar embryony nucellus cells that can develop into apomictic embryos that are genetically identical to the mother plant. Diploidy is the general rule in citrus and related genera of Aurantioideae with a basic chromosome number $x=9$. The seedless citrus are produced through parthenocarpy. With self-incompatible varieties, self-pollination does not work because the pollen tube grows down the style into the ovary (fruit) too slowly and sexual fertilization does not actually occur. The International Citrus Genome Consortium (ICGC) which was organized in 2003 aimed at developing useful genomic resources for citrus genetics and breeding research. Draft genome sequences of several citrus species have been released in genomic databases through the Citrus Annotation Project (CAP) (Wang et al 2014) and Phytozome (Wu et al 2014, 2018) with the availability of reference genomes of sweet orange, wild mandarin etc. (Xu et al 2013; Wang et al 2018; Wu et al 2014; Wang et al 2017).

Genome-wide association study and genomic prediction for fruit quality traits was also studied in citrus (Minamikawa, 2017). Indian citron (Citrus medica L.) is one of the important citrus fruits worldwide, with a production that stands at 122 million tons. It is grown in a wild or semi-wild state in the forests of the Himalayan and North Eastern states in India. Uchoi et al (2017) studied the genetic diversity of 46 representative accessions using 17 RAPD and 11 ISSR markers and found $82 \%$ and $73 \%$ polymorphism, respectively. This suggests the existence of huge genetic variability among citron species. Citrus macroptera Montr. (Melanesian papeda) is wild, endangered but an economically important species of northeastern India. In order to understand the genetic variability among 30 C. macroptera accessions from Tripura and Mizoram states, Malik et al (2012) generated 91 polymorphic bands (98.8\%) using 12 RAPD primers. They reported 0.26-1.00 pair-wise genetic similarity value between the accessions, indicating the existence of high level genetic diversity among these accessions. Comparative transcriptome analysis in ovules of $C$. sinensis revealed the stress-related genes and three novel ORFs associated with nucellar polyembryony (Kumar et al 2014). The Citrus Genomic Variation Database V1.0 (CitGVD) contains 1,493,258,964 non-redundant SNPs and INDELs and 84 phenotypes from 346 citrus individuals (http://citgvd.cric.cn/home).

\section{xxxv. Juglans sps. (Walnut)}

Walnut (Juglans spp.) belongs to the family Juglandaceae, order Fagales and is a diploid species $(2 n=32)$. The genus Juglans broadly comprises 21 species. Persian walnut (J. 
regia) originated from Iran (Persia) and is particularly known for its high quality nut production. The species of Juglans genus are valued for high quality timber production worldwide. Walnut has been cultivated since the Greek era, and is native to the region from the Balkans eastward to the Western Himalaya. It is cherished for its nutritious kernel and wood (Fernandez-Lopez et al 2000). In India, J. regia is commonly found in the Himalayan states. The North Western Himalayan region is known for walnut (J. regia) production and has maximum variability (Chand et al 2017). In walnut, natural cross pollination rules due to monoecism and heterodichogamy and it is a wind-pollinated tree with $2 \mathrm{n}=32$ chromosomes.

Marrano et al (2019) carried out GWAS for development of SNPs and developed a highdensity 700K SNP array in Persian walnut. Over 609K high-quality SNPs have been selected from a set of 9.6 M genome-wide variants, previously identified from the highdepth re-sequencing of 27 founders of the Walnut Improvement Program (WIP) of University of California, Davis. The effectiveness of the array was validated using a genotyped collection of 1,284 walnut trees, including 1,167 progeny of 48 WIP families and 26 walnut cultivars. Unravelling the genetic architecture of agronomic traits in walnut such as budbreak date and bearing habit, is crucial for climate change adaptation and yield improvement. Bernard et al (2020) conducted GWAS using multi-locus models in a panel of 170 walnut accessions genotyped using the Axiom ${ }^{\mathrm{TM}} \mathrm{J}$. regia $700 \mathrm{~K} \mathrm{SNP}$ array, with phenological data from 2018, 2019 and legacy data. Using GWAS, they reported strong associations of SNPs located at the beginning of chromosome 1 with both budbreak and female flowering dates. Highly significant associated SNPs were also detected using GWAS for heterodichogamy and lateral bearing habit, both on chromosome 11. A Kompetitive Allele Specific PCR (KASP) marker for budbreak date in walnut was developed, and validated using plant material from the Walnut Improvement Program of the University of California, Davis. Candidate genes involved in flowering events in walnut identified, including a gene related to heterodichogamy encoding, a sugar catabolism enzyme and cell division-related genes linked to flowering. 
Table 2. Major achievements of tree biotechnology studies at global level

\begin{tabular}{|c|c|c|c|}
\hline & Tree species & Major findings / achievements & Reference \\
\hline \multirow[t]{7}{*}{1} & \multirow[t]{7}{*}{$\begin{array}{l}\text { Neem } \\
\text { (Azadirachta } \\
\text { indica) }\end{array}$} & $\begin{array}{l}\text { RAPD analysis to assess genetic } \\
\text { divergence among } 29 \text { Azadirachta indica } \\
\text { accessions collected from two agro- } \\
\text { ecological regions of India }\end{array}$ & $\begin{array}{l}\text { Deshwal et al ( } \\
\text { 2003) }\end{array}$ \\
\hline & & $\begin{array}{l}\text { Chromosome number estimated to be } \\
2 n=28 \text { by enzymatic maceration and air } \\
\text { drying method (EMA) }\end{array}$ & Jha (2014) \\
\hline & & $\begin{array}{l}\text { Draft genome (v1.0) and four } \\
\text { transcriptomes }\end{array}$ & $\begin{array}{l}\text { Krishnan et al } \\
\text { (2012) }\end{array}$ \\
\hline & & Improved Genome Assembly (v2.0) & $\begin{array}{l}\text { Krishnan et al } \\
\text { (2016) }\end{array}$ \\
\hline & & $\begin{array}{llll}\text { Transcriptome study for terpenoid } \\
\text { production }\end{array}$ & $\begin{array}{l}\text { Kuravadi et al } \\
\text { (2015); Wang et } \\
\text { al (2016) }\end{array}$ \\
\hline & & $\begin{array}{l}\text { Identified key enzymes responsible for } \\
\text { protolimonoid biosynthesis }\end{array}$ & $\begin{array}{l}\text { Hodgson et al } \\
\text { (2019) }\end{array}$ \\
\hline & & $\begin{array}{l}\text { High quality PCR usable DNA isolation } \\
\text { from neem }\end{array}$ & $\begin{array}{l}\text { Rajarajan et al } \\
\text { (2015) }\end{array}$ \\
\hline \multirow[t]{3}{*}{2} & \multirow[t]{3}{*}{$\begin{array}{l}\text { Shisham } \\
\text { (Dalbergia sissoo) }\end{array}$} & $\begin{array}{l}\text { Complete chloroplast genome sequencing } \\
\text { by comparison of nine Dalbergia species }\end{array}$ & $\begin{array}{lll}\text { Song et } & \text { al } \\
(2019) & & \end{array}$ \\
\hline & & $\begin{array}{l}\text { Genetic polymorphism in Dalbergia sissoo } \\
\text { genotypes Using RAPD markers }\end{array}$ & $\begin{array}{l}\text { Dobhal et al } \\
(2019)\end{array}$ \\
\hline & & $\begin{array}{l}\text { Genetic diversity in Dalbergia sissoo } \\
\text { through ISSR markers }\end{array}$ & $\begin{array}{lll}\text { Javaid et al } \\
\text { (2014) }\end{array}$ \\
\hline
\end{tabular}




\begin{tabular}{|c|c|c|c|}
\hline & & $\begin{array}{l}\text { Species phylogentic genetic relationship } \\
\text { among Dalbergia species through } \\
\text { molecular markers }\end{array}$ & $\begin{array}{l}\text { Hiremath et al } \\
\text { (2004) }\end{array}$ \\
\hline \multirow[t]{9}{*}{3} & \multirow[t]{9}{*}{$\begin{array}{l}\text { Teak (Tectona } \\
\text { grandis) }\end{array}$} & $\begin{array}{l}\text { Efficacy of DNA extraction methods for } \\
\text { PCR-based assay }\end{array}$ & $\begin{array}{l}\text { Narayanan et al } \\
(2008)\end{array}$ \\
\hline & & $\begin{array}{l}\text { Evaluation of genetic diversity and } \\
\text { population structure in Indian teak } \\
\text { populations }\end{array}$ & $\begin{array}{l}\text { Nicodemus et al } \\
\text { (2005) }\end{array}$ \\
\hline & & $\begin{array}{l}\text { Diversity and genetic structure analysis } \\
\text { using ISSR marker to distinguish drier teak } \\
\text { populations of central India from the moist } \\
\text { teak populations of south India. }\end{array}$ & $\begin{array}{lll}\text { Ansari et al } \\
(2012)\end{array}$ \\
\hline & & $\begin{array}{l}\text { Genetic diversity and structure analysis } \\
\text { using AFLP marker. }\end{array}$ & $\begin{array}{l}\text { Vaishnav et al } \\
\text { (2015) }\end{array}$ \\
\hline & & $\begin{array}{l}\text { The genetic differentiation of teak meta- } \\
\text { population to geographical and climatic } \\
\text { variations using ISSR }\end{array}$ & $\begin{array}{l}\text { Vaishnav et al } \\
\text { (2018) }\end{array}$ \\
\hline & & $\begin{array}{l}\text { Developed a widely expressed gene } \\
\text { catalog using Illumina technology and the } \\
\text { de novo assembly }\end{array}$ & $\begin{array}{l}\text { Galeano et al } \\
(2015)\end{array}$ \\
\hline & & $\begin{array}{l}\text { Physiological and molecular responses to } \\
\text { drought stress }\end{array}$ & $\begin{array}{l}\text { Galeano et al } \\
(2019)\end{array}$ \\
\hline & & $\begin{array}{l}\text { Identification of } 156 \text { SNP markers and } \\
\text { validation in } 20 \text { teak population of } \\
\text { Mayanmar }\end{array}$ & $\begin{array}{l}\text { Dunker et al } \\
\text { (2019) }\end{array}$ \\
\hline & & $\begin{array}{l}\text { Draft genome of } 317 \mathrm{Mbp} \text { at } 151 \text { coverage } \\
\text { and annotation of } 36,172 \text { protein-coding } \\
\text { genes. }\end{array}$ & $\begin{array}{l}\text { Yasodha et al } \\
\text { (2018) }\end{array}$ \\
\hline
\end{tabular}




\begin{tabular}{|c|c|c|c|}
\hline & & $\begin{array}{l}\text { A chromosomal-scale genome assembly of } \\
\text { Tectona grandis }\end{array}$ & $\begin{array}{lll}\text { Zhao et } & \text { al } \\
(2019) & & \end{array}$ \\
\hline \multirow[t]{2}{*}{2} & \multirow[t]{2}{*}{$\begin{array}{l}\text { Subabul } \\
\text { (Leucaena } \\
\text { leucocephala) }\end{array}$} & $\begin{array}{l}\text { Identification of species-specific genes } \\
\text { using inter-species suppression } \\
\text { subtractive hybridization }\end{array}$ & Negi et al (2011) \\
\hline & & $\begin{array}{l}\text { Transcriptome analysis and identification } \\
\text { of highly expressed genes in root and } \\
\text { shoot }\end{array}$ & $\begin{array}{l}\text { Ishihara et al } \\
\text { (2016b) }\end{array}$ \\
\hline \multirow[t]{3}{*}{5} & \multirow[t]{3}{*}{$\begin{array}{l}\text { Malabar Neem } \\
\text { (Melia dubia) }\end{array}$} & $\begin{array}{l}\text { Evaluation of genetic diversity using RAPD } \\
\text { markers }\end{array}$ & $\begin{array}{lll}\text { Johar et } & \text { al } \\
(2017) & & \end{array}$ \\
\hline & & $\begin{array}{l}\text { Genetic variations among open pollinated } \\
\text { families of selected trees }\end{array}$ & $\begin{array}{l}\text { Kumar et al } \\
(2013)\end{array}$ \\
\hline & & $\begin{array}{l}\text { Genetic diversity assessment ISSR } \\
\text { markers among different }\end{array}$ & $\begin{array}{lll}\text { Rawat et al } \\
(2018)\end{array}$ \\
\hline \multirow[t]{3}{*}{6} & \multirow[t]{3}{*}{$\begin{array}{l}\text { Gamhar (Gmelina } \\
\text { arborea) }\end{array}$} & $\begin{array}{l}\text { Standardization of protocol for isolating } \\
\text { high quality DNA from dried leaves }\end{array}$ & $\begin{array}{l}\text { Shankar et al } \\
(2009)\end{array}$ \\
\hline & & $\begin{array}{l}\text { Genetic diversity assessments using ISSR } \\
\text { markers }\end{array}$ & Naik et al (2009) \\
\hline & & $\begin{array}{l}\text { Development of genetic markers for } G \text {. } \\
\text { arborea and G. asiatica based on the } \\
\text { nuclear ribosomal DNA- internal } \\
\text { transcribed spacer } 1 \text { (ITS1) region }\end{array}$ & $\begin{array}{l}\text { Manokar et al } \\
(2018)\end{array}$ \\
\hline \multirow[t]{3}{*}{7} & \multirow[t]{3}{*}{$\begin{array}{l}\text { Eucalyptus } \\
\text { Species }\end{array}$} & $\begin{array}{l}\text { Chromosome level assembly of } E \text {. grandis } \\
\text { genome }\end{array}$ & $\begin{array}{l}\text { Myburg et al } \\
(2014)\end{array}$ \\
\hline & & $\begin{array}{l}\text { Genomic selection for growth and wood } \\
\text { quality in Eucalyptus }\end{array}$ & $\begin{array}{l}\text { Resende et al } \\
(2012)\end{array}$ \\
\hline & & $\begin{array}{l}\text { DArT markers used for GWAS for growth } \\
\text { and wood traits over E. globulus population }\end{array}$ & $\begin{array}{lll}\text { Cappa } & \text { et } & \text { al } \\
(2013) & & \end{array}$ \\
\hline
\end{tabular}




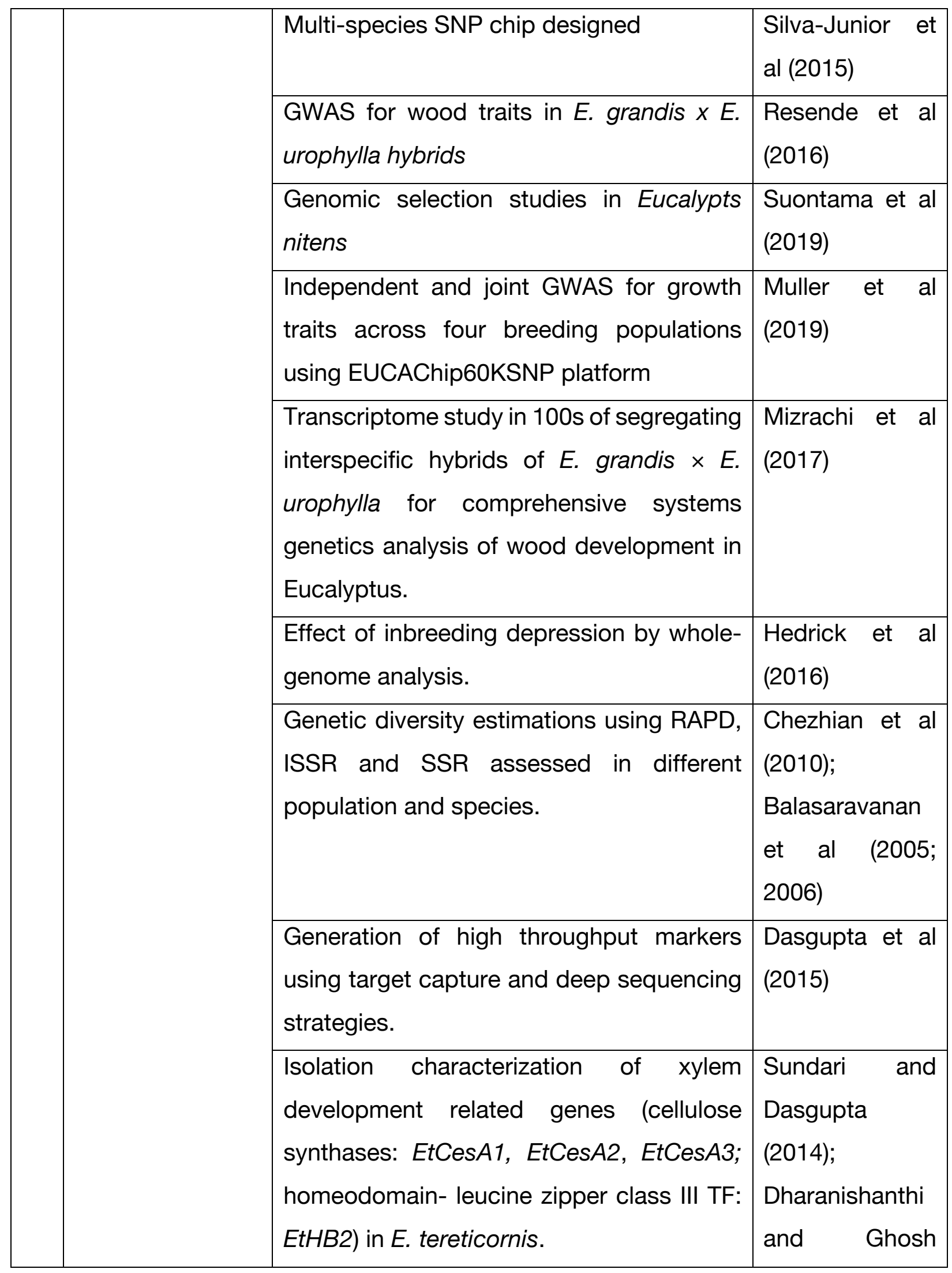




\begin{tabular}{|c|c|c|c|}
\hline & & & $\begin{array}{l}\text { Dasgupta } \\
\text { (2017) }\end{array}$ \\
\hline & & $\begin{array}{l}\text { Assessment of water stress responsive } \\
\text { genes and their expression in leaves of } E \text {. } \\
\text { grandis under water stress }\end{array}$ & $\begin{array}{l}\text { Ghosh } \\
\text { Dasgupta and } \\
\text { Dharanishanthi } \\
\text { (2017) }\end{array}$ \\
\hline & & $\begin{array}{l}\text { Study of co-expression network for } \\
\text { xylogenesis-related, secondary cell wall } \\
\text { biogenesis-related transcripts }\end{array}$ & $\begin{array}{l}\text { Dharanishanthi } \\
\text { and Ghosh } \\
\text { Dasgupta } \\
\text { (2016; 2018a) }\end{array}$ \\
\hline & & $\begin{array}{l}\text { Study of terpene biosynthesis, } \\
\text { reproductive biology, plant defense and } \\
\text { abiotic interactions }\end{array}$ & $\begin{array}{l}\text { Myburg et al } \\
\text { (2014); Kulheim } \\
\text { et al (2015); } \\
\text { Vining et al } \\
\text { (2015); Christie } \\
\text { et al (2015); } \\
\text { Mangwanda et } \\
\text { al (2015); Oates } \\
\text { et al (2015); } \\
\text { Meyer et al } \\
\text { 2016); Plett et al } \\
\text { (2015); } \\
\text { Spokevicius et } \\
\text { al (2017) }\end{array}$ \\
\hline 8 & $\begin{array}{l}\text { Poplar (Populus } \\
\text { species) }\end{array}$ & $\begin{array}{l}\text { Physical map of Populus trichocarpa using } \\
\text { shotgun strategy }\end{array}$ & $\begin{array}{l}\text { Tuskan et al } \\
\text { (2006) }\end{array}$ \\
\hline & & $\begin{array}{l}\text { Identification of candidate genes/SNPs for } \\
\text { lignin and cellulose biosynthesis traits in } P \text {. } \\
\text { trichocapa }\end{array}$ & $\begin{array}{l}\text { Wegrzyn et al } \\
(2010)\end{array}$ \\
\hline
\end{tabular}




\begin{tabular}{|c|c|c|c|}
\hline & & $\begin{array}{l}\text { Methylation maps for } 10 \text { tissue types in } \\
\text { Populus trichocarpa }\end{array}$ & $\begin{array}{lll}\text { Vining et } & \text { al } \\
(2012) & & \end{array}$ \\
\hline & & $\begin{array}{l}\text { GWAS for wood related traits in } P \text {. } \\
\text { trichocarpa }\end{array}$ & $\begin{array}{lll}\text { Porth et } & \text { al } \\
(2013) & & \end{array}$ \\
\hline & & $\begin{array}{l}\text { QTL mapping and candidate genes for cell } \\
\text { wall properities. }\end{array}$ & $\begin{array}{l}\text { Muchero et al } \\
(2014)\end{array}$ \\
\hline & & $\begin{array}{l}\text { GWAS for adaptive traits in } P \text {. trichocarpa } \\
\text { and bioenergy traits in } P \text {. deltoids }\end{array}$ & $\begin{array}{l}\text { Evans et al } \\
(2014) \\
\text { Fahrenkrog et al } \\
(2017)\end{array}$ \\
\hline & & $\begin{array}{l}\text { GWAS and QTL analysis in Populus to } \\
\text { identify regulation of chlorogenic acid }\end{array}$ & $\begin{array}{l}\text { Zhang et al } \\
(2018)\end{array}$ \\
\hline & & $\begin{array}{l}\text { Devlopment of highly contiguous, de novo } \\
\text { genome assemblies in } P \text {. euphratica }\end{array}$ & Ma et al (2014) \\
\hline & & $\begin{array}{l}\text { Methods to integrate SNP, gene } \\
\text { expression, transcription factor binding, } \\
\text { gene dosage, methylation, metabolite } \\
\text { expression, phenome, and co-evolutionary } \\
\text { relationships have been developed to } \\
\text { generate a systems biology view of the } \\
\text { molecular and regulatory interactions that } \\
\text { lead to organismal scale traits. }\end{array}$ & $\begin{array}{l}\text { Henry et al } \\
(2015) \text { Liu et al } \\
(2015) \text {; Joubert } \\
\text { et al (2017, } \\
\text { 2018); Weighill } \\
\text { et al (2018) }\end{array}$ \\
\hline 9 & Acacia species & $\begin{array}{l}\text { Studied the involvement of six highly } \\
\text { conserved amg-miRNA families viz., amg- } \\
\text { miR166, amg-miR172, amg-miR168, amg- } \\
\text { miR159, amg-miR394 and amg-miR156 in } \\
\text { secondary cell wall biosynthesis in Acacia } \\
\text { mangium }\end{array}$ & $\begin{array}{l}\text { Ong and } \\
\text { Wickneswari } \\
(2011,2012)\end{array}$ \\
\hline
\end{tabular}




\begin{tabular}{|c|c|c|c|}
\hline & & $\begin{array}{l}\text { Identification of genes involved in lignin } \\
\text { biosynthesis and secondary cell wall } \\
\text { formation in Acacia hybrids }\end{array}$ & $\begin{array}{l}\text { Wong et al } \\
(2011)\end{array}$ \\
\hline & & $\begin{array}{l}\text { Identification of } 37,786 \text { putative SNPs in } \\
\text { Acacia auriculiformis } \times \text { Acacia mangium } \\
\text { hybrids }\end{array}$ & $\begin{array}{lll}\text { Wong } & \text { et } & \text { al } \\
(2012) & & \end{array}$ \\
\hline & & $\begin{array}{l}\text { First } c p \text { genome of } A \text {. ligulata with } 158,724 \\
\text { bp and revealed } c / p P 1 \text { gene which is highly } \\
\text { divergent and essential part of it }\end{array}$ & $\begin{array}{l}\text { Williams et al } \\
(2015)\end{array}$ \\
\hline 10 & $\begin{array}{l}\text { Sandalwood } \\
\text { (Santalum album) }\end{array}$ & $\begin{array}{l}\text { Isolation of sequences encoding farnesyl } \\
\text { diphosphate synthase and santalene } \\
\text { synthase enzyme }\end{array}$ & Rani et al (2013) \\
\hline & & $\begin{array}{l}\text { Draft genome sequence with } 221 \mathrm{Mbp} \\
\text { genome size. It includes } 38,119 \text { protein } \\
\text { coding genes, } 27.42 \% \text { repetitive DNA } \\
\text { elements, } 72,325 \text { unique peptides, } 53 \\
\text { novel proteins and } 1,348 \text { potential } \\
\text { noncoding RNAs }\end{array}$ & $\begin{array}{l}\text { Mahesh et al } \\
(2018)\end{array}$ \\
\hline & & $\begin{array}{l}\text { Draft genome sequence with } 286 \mathrm{Mbp} \text { size } \\
\text { containing } 37,500 \text { genes ( } 30 \text { genes from } \\
\text { terpene synthase gene family) along with } \\
1,191,838 \quad(0.42 \%) \text { SNPs and } 98,312 \\
(0.034 \%) \text { InDels. Also reconstruction of } \\
\text { consensus cp genome with } 147.25 \mathrm{Kbp} \\
\text { size }\end{array}$ & $\begin{array}{l}\text { Dasgupta et al } \\
(2019)\end{array}$ \\
\hline & & $\begin{array}{l}\text { First complete cp genome sequence of } S \text {. } \\
\text { album with } 144,101 \text { bp size containing } 123 \\
\text { genes, including } 80 \text { protein-coding genes, } \\
8 \text { rRNA genes, and } 35 \text { tRNA genes. }\end{array}$ & $\begin{array}{lll}\text { Yang } & \text { et } & \text { al } \\
(2020) & & \\
\end{array}$ \\
\hline
\end{tabular}




\begin{tabular}{|c|c|c|c|}
\hline & & $\begin{array}{l}\text { The transferability of Santalum } \\
\text { austrocaledonicum and Santalum insulare } \\
\text { SSRs to Santalum album was evaluated to } \\
\text { examine molecular diversity of } 20 \\
\text { accessions of two diverse localities } \\
\text { comprising germplasm of MP and } \\
\text { Karnataka. }\end{array}$ & $\begin{array}{l}\text { Mohammad et } \\
\text { al (2012) }\end{array}$ \\
\hline \multirow[t]{5}{*}{11} & \multirow{5}{*}{$\begin{array}{l}\text { Karanj } \\
\text { (Pongamia } \\
\text { pinnata) }\end{array}$} & $\begin{array}{l}\text { Genome size variation through somoclonal } \\
\text { variation in Pongamia pinnata }\end{array}$ & $\begin{array}{l}\text { Choudhury et al } \\
\text { (2014) }\end{array}$ \\
\hline & & $\begin{array}{l}\text { Identified } 236 \text { conserved miRNAs within } 49 \\
\text { families and } 143 \text { novel miRNAs via deep } \\
\text { sequencing of Pongamia seeds sampled at } \\
\text { three developmental phases }\end{array}$ & Jin et al (2019) \\
\hline & & $\begin{array}{l}\text { sequencing and annotation of chloroplast } \\
\text { and mitochondrial genome (152,968 and } \\
425,718 \mathrm{bp} \text {, respectively) }\end{array}$ & $\begin{array}{l}\text { Biswas et al } \\
(2013)\end{array}$ \\
\hline & & $\begin{array}{l}\text { Whole transcriptome analysis of Pongamia } \\
\text { to unravel genes underlying floral initiation } \\
\text { to lipid biosynthesis }\end{array}$ & $\begin{array}{l}\text { Sreeharsha et al } \\
\text { (2016) }\end{array}$ \\
\hline & & $\begin{array}{l}\text { Genetic diversity in } 37 \text { wild species of } P \text {. } \\
\text { pinnata using } 18 \text { RAPD and } 23 \text { SRAP } \\
\text { markers }\end{array}$ & $\begin{array}{l}\text { Kole et al } \\
(2015 b)\end{array}$ \\
\hline \multirow[t]{3}{*}{12} & \multirow{3}{*}{$\begin{array}{l}\text { Casuarina } \\
\text { equisetifolia }\end{array}$} & $300 \mathrm{Mb}$ draft genome sequence. & Ye et al (2019) \\
\hline & & $\begin{array}{l}\text { Genetic diversity assessment in } \\
\text { Allocasuarina, and Casuarina species. }\end{array}$ & $\begin{array}{l}\text { Yasodha et al } \\
\text { (2004) }\end{array}$ \\
\hline & & $\begin{array}{l}\text { Development of species diagnostic ISSR- } \\
\text { SCAR markers for Casuarina equisetifolia } \\
\text { and C. junghuhniana. }\end{array}$ & $\begin{array}{l}\text { Ghosh et al } \\
(2011) ; \\
\text { Nicodemus et al } \\
(2011)\end{array}$ \\
\hline
\end{tabular}




\begin{tabular}{|c|c|c|c|}
\hline & & $\begin{array}{l}\text { Molecular mechanism during Casuarina } \\
\text { equisetifolia - Trichosporium vesiculosum } \\
\text { was assessed and transcript profiling } \\
\text { during elicitation revealed expression of } \\
\text { resistance genes; cytochrome oxidase; } \\
\text { trans membrane proteins; genes involved } \\
\text { in programmed cell death like } 265 \\
\text { proteasome and ubiquit in activating } \\
\text { enzyme; early nodulin gene, wound } \\
\text { inducible metallocarboxy peptidase } \\
\text { inhibitor, glucanase, metal binding protein } \\
\text { and signal recognition particle }\end{array}$ & $\begin{array}{l}\text { Ghosh } \\
\text { Dasgupta et al } \\
(2013)\end{array}$ \\
\hline & & $\begin{array}{l}\text { A class I chitinase (CeChi1) belonging to } \\
\text { PR-3 is identified to be upregulates during } \\
\text { pathogen elicitation and salicylic acid } \\
\text { signaling }\end{array}$ & $\begin{array}{l}\text { Veluthakkal and } \\
\text { Ghosh } \\
\text { Dasgupta } \\
\text { (2012) }\end{array}$ \\
\hline & & $\begin{array}{l}\text { CeChi1 results in characteristic lysis of } \\
\text { hyphal tips of pathogenic fungi including } \\
\text { Trichosporium vesiculosum, Fusarium } \\
\text { oxysporum and Rhizoctonia solani }\end{array}$ & $\begin{array}{l}\text { Veluthakkal and } \\
\text { Ghosh } \\
\text { Dasgupta } \\
\text { (2015) }\end{array}$ \\
\hline & & $\begin{array}{l}\text { The transcriptome of the developing } \\
\text { secondary tissues of } 15 \text { years old } \\
\text { Casuarina equiseitfolia sub sp. equisetifolia } \\
\text { was sequenced, de novo assembled, } \\
\text { annotated and mapped to functional } \\
\text { pathways. }\end{array}$ & $\begin{array}{l}\text { Vikashini et al } \\
\text { (2018) }\end{array}$ \\
\hline 13 & $\begin{array}{l}\text { Tree of Heaven } \\
\text { (Ailanthus } \\
\text { excelsa) }\end{array}$ & $\begin{array}{l}\text { Wood transcriptome of a } 22 \text { month old tree } \\
\text { was sequenced and de novo assembled. A }\end{array}$ & $\begin{array}{l}\text { Unpublished } \\
\text { data from } \\
\text { IFGTB }\end{array}$ \\
\hline
\end{tabular}




\begin{tabular}{|c|c|c|c|}
\hline & & $\begin{array}{l}\text { total of } 48,493 \text { transcripts were predicted } \\
\text { with } N 50 \text { of } 1,606 \mathrm{bp} \text {. }\end{array}$ & $\begin{array}{l}\text { Coimbatore, } \\
\text { India }\end{array}$ \\
\hline 14 & $\begin{array}{l}\text { Rotan Dahan } \\
\text { (Korthalsia } \\
\text { laciniosa) }\end{array}$ & $\begin{array}{l}\text { Draft genome sequence of Korthalsia } \\
\text { laciniosa (Griff.) Mart., a clustering rattan, } \\
\text { was generated and the reads were } \\
\text { assembled into } 243005 \text { scaffolds with N50 } \\
\text { of } 23,613 \mathrm{bp} \text {. }\end{array}$ & $\begin{array}{l}\text { Ghosh } \\
\text { Dasgupta et al } \\
\text { (2020) } \\
\text { unpublished } \\
\text { data }\end{array}$ \\
\hline \multirow[t]{7}{*}{15} & \multirow[t]{7}{*}{ Morus species } & $\begin{array}{l}\text { Draft genome sequence of Morus notablis } \\
\text { (Mulberry) }\end{array}$ & He et al (2013) \\
\hline & & $\begin{array}{l}\text { Mining of } 217,312 \text { SSRs from genome } \\
\text { sequence and } 961 \text { SSRs from EST } \\
\text { sequences of } M \text {. notabilis }\end{array}$ & $\begin{array}{l}\text { Krishnan et al } \\
\text { (2014) }\end{array}$ \\
\hline & & $\begin{array}{l}\text { Generation of } 87.0 \text { and } 80.3 \text { Mbp of } \\
\text { transcriptomic data from } M \text {. laevigata and } \\
\text { M. serrata, and identification of } 24,049 \\
\text { SSRs, } 1,201,326 \text { SNPs and } 67,875 \text { InDels }\end{array}$ & $\begin{array}{lll}\text { Saeed et al } \\
(2016)\end{array}$ \\
\hline & & $\begin{array}{l}\text { Identified and characterized } 222 \text { genomic } \\
\text { and } 136 \text { genic SSRs from genomic clones } \\
\text { and ESTs of M. alba }\end{array}$ & $\begin{array}{l}\text { Thumilan et al } \\
\text { (2013) }\end{array}$ \\
\hline & & $\begin{array}{l}\text { Development and validation of } 206 \text { EST } \\
\text { driven SSRs from transcriptomic data of } \\
\text { drought tolerant mulberry } \mathrm{cv} \text {. Dudia white }\end{array}$ & $\begin{array}{l}\text { Thumilan et al } \\
\text { (2016) }\end{array}$ \\
\hline & & $\begin{array}{l}\text { Identification of drought-regulated genes } \\
\text { and large number of ESTs through } \\
\text { suppression subtractive hybridization of K2 } \\
\text { (drought susceptible) } \times \text { AR12 (drought } \\
\text { tolerant) }\end{array}$ & $\begin{array}{l}\text { Gulyani and } \\
\text { Khurana (2011) }\end{array}$ \\
\hline & & $\begin{array}{l}248 \text { Genomic-SSR and } 490 \text { genic-SSR } \\
\text { (EST-SSR) primers designed }\end{array}$ & $\begin{array}{l}\text { Sarkar et al } \\
(2017)\end{array}$ \\
\hline
\end{tabular}




\begin{tabular}{|c|c|c|c|}
\hline 15 & $\begin{array}{l}\text { Frankincense } \\
\text { (Boswellia sacra) }\end{array}$ & $\begin{array}{l}\text { Sequencing of cp genome and revealed of } \\
160,543 \text { bp size with } 37.61 \% \text { GC content } \\
\text { and } 114 \text { unique genes with } 83 \text { protein- } \\
\text { coding regions }\end{array}$ & $\begin{array}{l}\text { Khan et al } \\
(2017)\end{array}$ \\
\hline \multirow[t]{4}{*}{17} & \multirow[t]{4}{*}{$\begin{array}{l}\text { Drumstick } \\
\text { (Moringa oleifera) }\end{array}$} & Draft genome sequence & $\begin{array}{l}\text { Chang et al } \\
\text { (2018); African } \\
\text { Orphan Crops } \\
\text { Consortium }\end{array}$ \\
\hline & & $\begin{array}{l}\text { Developed a bioinformatics pipeline to } \\
\text { assemble transcriptome, along with the } \\
\text { previously published } M \text {. oleifera genome, } \\
\text { to predict } 17,148 \text { gene models. }\end{array}$ & $\begin{array}{lll}\text { Pasha et al } \\
(2019)\end{array}$ \\
\hline & & $\begin{array}{l}\text { Report a high-quality draft genome } \\
\text { sequence of } M \text {. oleifera and represents } \\
91.78 \% \text { of the estimated genome size and } \\
\text { contains } 19,465 \text { protein-coding genes. }\end{array}$ & Tian et al (2015) \\
\hline & & $\begin{array}{l}\text { The first complete chloroplast genome } \\
\text { sequence of } M \text {. oleifera (accession number } \\
\text { of } \mathrm{MH} 778650 \text { ) }\end{array}$ & Liu et al (2019) \\
\hline \multirow[t]{3}{*}{18} & \multirow[t]{3}{*}{$\begin{array}{l}\text { White siris } \\
\text { (Albizia procera) }\end{array}$} & $\begin{array}{l}\text { Study of genetic diversity through AFLP } \\
\text { markers }\end{array}$ & $\begin{array}{l}\text { Aparajita et al } \\
(2010)\end{array}$ \\
\hline & & $\begin{array}{l}\text { RAPD and ISSR markers to authenticate } \\
\text { the true to type nature of in vitro raised } \\
\text { plantlets }\end{array}$ & $\begin{array}{l}\text { Mohammad et } \\
\text { al (2016) }\end{array}$ \\
\hline & & $\begin{array}{l}\text { Genetic variations between and within the } \\
\text { populations white siris using ISSR markers }\end{array}$ & $\begin{array}{l}\text { Aparajita et al } \\
(2016)\end{array}$ \\
\hline 19 & & Breeding system and pollination biology & $\begin{array}{lll}\text { Diallo et } & \text { al } \\
(2007) & & \end{array}$ \\
\hline
\end{tabular}




\begin{tabular}{|c|c|c|c|}
\hline & $\begin{array}{l}\text { Tamarind } \\
\text { (Tamarindus } \\
\text { indica) }\end{array}$ & $\begin{array}{l}\text { Differential gene expression and } \\
\text { biochemical activities of antioxident } \\
\text { enzymes in Tamarind }\end{array}$ & Lim et al (2013) \\
\hline & & $\begin{array}{l}\text { Assessment of genetic diversity using } \\
\text { RAPD markers }\end{array}$ & $\begin{array}{lll}\text { Diallo et } & \text { al } \\
(2007) & & \end{array}$ \\
\hline 20 & $\begin{array}{l}\text { Custard Apple } \\
\text { (Annona } \\
\text { squamosa L.) }\end{array}$ & $\begin{array}{l}\text { Transcriptome analysis of early-stage fruit } \\
\text { of two genotypes with contrast in seed } \\
\text { number }\end{array}$ & $\begin{array}{lll}\text { Gupta } & \text { et } & \text { al } \\
(2015) & & \end{array}$ \\
\hline & & $\begin{array}{l}\text { Transcriptome analyses of normal and } \\
\text { malformed flowers }\end{array}$ & Liu et al (2017) \\
\hline & & $\begin{array}{l}\text { Genetic diversity among } 20 \text { Annona } \\
\text { genotypes representing five different } \\
\text { species of Annonaceae using } 11 \text { RAPD and } \\
12 \text { SSRs markers }\end{array}$ & $\begin{array}{l}\text { Anuragi et al } \\
\text { (2016) }\end{array}$ \\
\hline 21 & $\begin{array}{l}\text { Jamun (Syzygium } \\
\text { cumini) }\end{array}$ & $\begin{array}{l}\text { Molecular characterization and diversity } \\
\text { analysis by RAPD, ISSR and SSR markers }\end{array}$ & $\begin{array}{l}\text { Ahmad et al } \\
(2012) ; \text { Shakya } \\
\text { et al (2010) }\end{array}$ \\
\hline & & Chloroplast genome sequencing & Asif et al (2013) \\
\hline 24 & $\begin{array}{l}\text { Guggul } \\
\text { (Commiphora }\end{array}$ & $\begin{array}{l}\text { Genetic diversity using RAPD and ISSR } \\
\text { markers }\end{array}$ & $\begin{array}{l}\text { Harish et al } \\
(2014)\end{array}$ \\
\hline & wightii) & $\begin{array}{l}\text { Study of genetic reltionships among } 24 \\
\text { genotypes of C. wightii using } 60 \text { RAPD and } \\
27 \text { ISSR markers }\end{array}$ & $\begin{array}{l}\text { Samantaray et } \\
\text { al (2011) }\end{array}$ \\
\hline & & $\begin{array}{l}\text { Genetic diversity assessments among } 7 \\
\text { populations of } C \text {. wightii using RAPD } \\
\text { markers. }\end{array}$ & $\begin{array}{l}\text { Haque et al } \\
(2009 b)\end{array}$ \\
\hline & & $\begin{array}{l}\text { Identification of sex-specific molecular } \\
\text { markers in dioeceious and hermaphrodite } \\
\text { plants of C. wightii using RAPD markers. }\end{array}$ & $\begin{array}{l}\text { Samantaray et } \\
\text { al (2009) }\end{array}$ \\
\hline
\end{tabular}




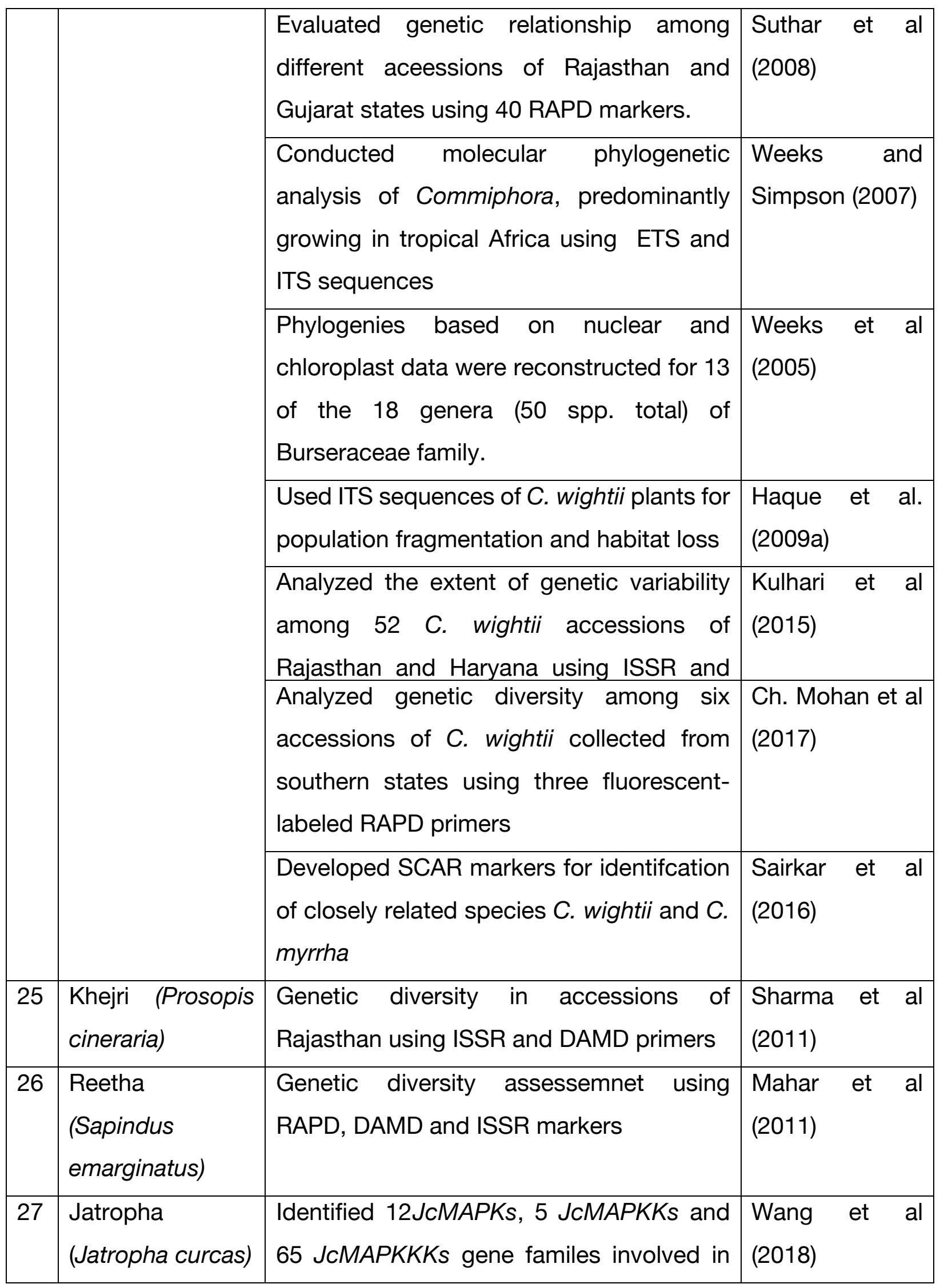




\begin{tabular}{|c|c|c|c|}
\hline & & $\begin{array}{l}\text { cell division, hormone signaling and overall } \\
\text { growth and get activated in under variety of } \\
\text { biotic and abiotic stresses }\end{array}$ & \\
\hline & & $\begin{array}{l}\text { Reported } \sim 339 \mathrm{Mbp} \text { draft whole genome } \\
\text { sequence in Chai Nat variety and identified } \\
\text { genes relevant to the biosynthesis of lipids } \\
\text { and toxic compounds during seed } \\
\text { development. }\end{array}$ & Ha et al (2019) \\
\hline & & $\begin{array}{l}\text { Generated hybrid de novo genome } \\
\text { assembly with } 265.7 \text { Mbp using Illumina } \\
\text { and PacBio sequencing technologies }\end{array}$ & \begin{tabular}{|l} 
Kancharla et al \\
$(2019)$
\end{tabular} \\
\hline & & $\begin{array}{l}\text { genetic variability and relationship among } \\
182 \text { accessions collected from } 19 \text { Indian } \\
\text { states } 30 \text { RAPD markers }\end{array}$ & $\begin{array}{|lll|}\text { Kole et } & \text { al } \\
(2015 a) & & \end{array}$ \\
\hline 28 & $\begin{array}{l}\text { Mango } \\
\text { (Mangifera } \\
\text { indica) }\end{array}$ & $\begin{array}{l}\text { Phase separated maternal (Dashehari) and } \\
\text { paternal (Neelam) genome assemblies of } \\
\text { highly heterozygous mango genome } \\
\text { (Mangifera indica cv. Amrapali) have been } \\
\text { developed using trio-binning of Illunina and } \\
\text { PacBio SMRT sequencing. Total } 53,018 \\
\text { genes were predicted from the mosaic } \\
\text { Amrapali genome assembly of } 403 \mathrm{Mbp} \text {. }\end{array}$ & \begin{tabular}{|ll} 
Singh et al \\
$(2016,2018)$
\end{tabular} \\
\hline & & $\begin{array}{l}\text { Leaf transcriptome analysis of Dashehari, } \\
\text { Neelam and Amrapali was done for genic- } \\
\text { SSR markers and estimation of } \\
\text { heterozygosity. }\end{array}$ & \begin{tabular}{|lll} 
Mahato et al \\
$(2016)$
\end{tabular} \\
\hline & & $\begin{array}{l}\text { Genome wide association study (GWAS) } \\
\text { has been conducted of pomological traits } \\
\text { in mango using genic-SSR markers }\end{array}$ & Lal et al (2017) \\
\hline
\end{tabular}




\begin{tabular}{|c|c|c|c|}
\hline & & Mango genomic SNP database (MiSNPdb) & $\begin{array}{l}\text { lquebal et al } \\
(2017)\end{array}$ \\
\hline & & $\begin{array}{l}\text { Mango fruit peel transcriptome analysis } \\
\text { was done to study the genes of } \\
\text { anthocyanin pigmentation pathways. }\end{array}$ & $\begin{array}{lll}\text { Bajpai } & \text { et } & \text { al } \\
(2018) & & \end{array}$ \\
\hline & & $\begin{array}{l}\text { Transcriptome analysis of flowering genes } \\
\text { in relation to floral malformation }\end{array}$ & $\begin{array}{lll}\text { Yadav et al } \\
(2019)\end{array}$ \\
\hline 29 & $\begin{array}{ll}\text { Pines } & \text { (Pinus } \\
\text { species) } & \end{array}$ & $\begin{array}{l}\text { High density SNP chip design for Maritime } \\
\text { pine (Pinus pinaster) }\end{array}$ & $\begin{array}{l}\text { Plomion et al } \\
(2016)\end{array}$ \\
\hline & & $\begin{array}{l}\text { Genomic selection predictions in Maritime } \\
\text { pine }\end{array}$ & $\begin{array}{l}\text { Bartholome et } \\
\text { al (2016) }\end{array}$ \\
\hline & & $\begin{array}{l}\text { Stochastic simulation study of SNP-based } \\
\text { genomic selection in conifers }\end{array}$ & $\begin{array}{l}\text { Li and Dungey } \\
(2018)\end{array}$ \\
\hline 30 & $\begin{array}{ll}\text { Spruces } & \text { (Picea } \\
\text { species) } & \end{array}$ & $\begin{array}{l}\text { Association genetics on } \sim 550 \text { candidate } \\
\text { genes for wood physical traits }\end{array}$ & $\begin{array}{l}\text { Beaulieu et al } \\
2011\end{array}$ \\
\hline & & $\begin{array}{l}\text { GWAS for productivity and wood quality } \\
\text { traits in White Spruce and Norway Spruce, } \\
\text { respectively. }\end{array}$ & $\begin{array}{l}\text { Beaulieu et al } \\
\text { (2014a); } \\
\text { Beaulieu et al } \\
(2014 b) \\
\text { Baison et al } \\
(2018)\end{array}$ \\
\hline 31 & $\begin{array}{l}\text { Apple (Malus } \\
\text { domestica) }\end{array}$ & $\begin{array}{l}\text { Genomic selection for fruit and key traits in } \\
\text { apple }\end{array}$ & $\begin{array}{l}\text { Kumar et al } \\
(2012) \\
\text { Muranty et al } \\
(2015)\end{array}$ \\
\hline & & $\begin{array}{l}\text { Genome wide association studies (GWAS) } \\
\text { for mapping flowering, ripening traits and } \\
\text { polyphenol content. }\end{array}$ & $\begin{array}{l}\text { Urrestarazu et } \\
\text { al (2015); } \\
\text { McClure et al } \\
(2019)\end{array}$ \\
\hline
\end{tabular}




\begin{tabular}{|c|c|c|c|}
\hline \multirow[t]{2}{*}{32} & \multirow[t]{2}{*}{$\begin{array}{l}\text { Peaches (Prunus } \\
\text { persica) }\end{array}$} & $\begin{array}{l}\text { GS for yield and quality traits using IPSC 9k } \\
\text { SNP array in Prunus persica }\end{array}$ & $\begin{array}{l}\text { Biscarini et al } \\
(2017)\end{array}$ \\
\hline & & GWAS for fruit shape in Prunus persica & Tan et al (2019) \\
\hline 33 & $\begin{array}{l}\text { Date palm } \\
\text { (Phoenix } \\
\text { dactylifera) }\end{array}$ & GWAS for fruit traits & $\begin{array}{l}\text { Hazzouri et al } \\
(2019)\end{array}$ \\
\hline 34 & $\begin{array}{l}\text { Oil Palm (Elaeis } \\
\text { guineensis) }\end{array}$ & GWAS for productivity traits & Cros et al (2015) \\
\hline \multirow[t]{4}{*}{35} & \multirow[t]{4}{*}{ Citrus species } & $\begin{array}{l}\text { GWAS for fruit quality traits in multiple } \\
\text { Citrus species }\end{array}$ & $\begin{array}{l}\text { Minamikawa et } \\
\text { al (2017) }\end{array}$ \\
\hline & & $\begin{array}{l}\text { Genetic diversity of forty-six representative } \\
\text { accessions using RAPD and ISSR markers. }\end{array}$ & $\begin{array}{lll}\text { Uchoi et } & \text { al } \\
(2017) & & \end{array}$ \\
\hline & & $\begin{array}{l}\text { Genetic variability among } 30 \text { C. macroptera } \\
\text { accessions from Tripura and Mizoram } \\
\text { states using RAPD markers. }\end{array}$ & $\begin{array}{l}\text { Malik et al } \\
(2012)\end{array}$ \\
\hline & & $\begin{array}{l}\text { Comparative transcriptome analysis in } \\
\text { ovules of C. sinensis }\end{array}$ & $\begin{array}{l}\text { Kumar et al } \\
\text { (2014). }\end{array}$ \\
\hline \multirow[t]{2}{*}{36} & \multirow{2}{*}{$\begin{array}{l}\text { Cocoa } \\
\text { (Theobroma } \\
\text { cacao) }\end{array}$} & 15k SNP chip development & III et al (2017) \\
\hline & & $\begin{array}{l}\text { GWAS and genomic prediction for fruit } \\
\text { yield and resistance to black and frosty pod } \\
\text { and disease resistance }\end{array}$ & $\begin{array}{l}\text { Navarro et al ( } \\
2017) \\
\text { McElroy et al } \\
(2018)\end{array}$ \\
\hline 37 & $\begin{array}{l}\text { Grapes } \quad \text { (Vitis } \\
\text { vinifera) }\end{array}$ & GWAS for important fruit traits & Guo et al (2019) \\
\hline 38 & $\begin{array}{l}\text { Macadamia nut } \\
\text { (Macadamia } \\
\text { integrifolia) }\end{array}$ & $\begin{array}{l}\text { GWAS for yield components in Macadamia } \\
\text { integrefolia }\end{array}$ & $\begin{array}{l}\text { O'Connor et al } \\
(2020)\end{array}$ \\
\hline
\end{tabular}




\begin{tabular}{|c|c|c|c|}
\hline 39 & $\begin{array}{l}\text { Banj Oak } \\
\text { (Quercus } \\
\text { leucotrichophora) }\end{array}$ & $\begin{array}{l}\text { Genetic diversity analysis in } 4 \text { natural } \\
\text { population from Himachal Pradesh using } \\
\text { RAPD markers }\end{array}$ & Saha (2018) \\
\hline \multirow[t]{3}{*}{40} & \multirow[t]{3}{*}{$\begin{array}{l}\text { Deodar (Cedrus } \\
\text { deodara) }\end{array}$} & $\begin{array}{l}\text { Study of genetic variation in three natural } \\
\text { populations of western himalaya using } \\
\text { RAPD markers. }\end{array}$ & Rai et al (2020) \\
\hline & & $\begin{array}{l}\text { Karyotype investigation and cytogenetic } \\
\text { study }\end{array}$ & $\begin{array}{l}\text { Dagher-Kharrat } \\
\text { (2001) }\end{array}$ \\
\hline & & Complete chloroplast sequence & Lin et al (2010) \\
\hline 41 & $\begin{array}{l}\text { Chinese } \\
\text { Bayberry (Myrica } \\
\text { esculenta) }\end{array}$ & $\begin{array}{l}\text { Development of } 158 \text { SSR markers by } \\
\text { genome survey }\end{array}$ & Jiao et al (2012) \\
\hline \multirow[t]{2}{*}{42} & \multirow[t]{2}{*}{$\begin{array}{l}\text { Himalayan Yew } \\
\text { (Taxus } \\
\text { wallichiana) }\end{array}$} & $\begin{array}{l}\text { Combination of transect study, population } \\
\text { genetic analyses based on chloroplast } \\
\text { DNA sequences and nuclear microsatellite } \\
\text { data, and ecological modelling used to } \\
\text { study Patterns of genetic variation }\end{array}$ & $\begin{array}{lll}\text { Poudel et al } \\
\text { (2014) }\end{array}$ \\
\hline & & Transcriptome study for taxol synthesis & $\begin{array}{lll}\text { Wang et al } & \\
(2019) & & \end{array}$ \\
\hline \multirow[t]{2}{*}{43} & \multirow{2}{*}{$\begin{array}{l}\text { Hamilton's } \\
\text { bamboo } \\
\text { (Dendrocalamus } \\
\text { hamiltonii) }\end{array}$} & $\begin{array}{l}\text { Genetic diversity analysis by molecular } \\
\text { markers }\end{array}$ & $\begin{array}{l}\text { Waikhom et al } \\
(2012) ; \text { Meena } \\
\text { et al (2019) }\end{array}$ \\
\hline & & $\begin{array}{l}\text { Genome-wide transcriptional profiling to } \\
\text { elucidate key candidates involved in bud } \\
\text { burst and rattling Growth }\end{array}$ & $\begin{array}{l}\text { Bhandawat et al } \\
\text { (2017) }\end{array}$ \\
\hline
\end{tabular}

The National Bureau of Plant Genetic Resources (NBPGR) aims to plan, coordinate and conduct explorations for collecting germplasm. It has the prime responsibility of characterization and evaluation of all the indigenous and exotic germplasm collections for their field performance and other important traits like resistance to biotic/abiotic 
stresses and phytochemical attributes along with maintenance and regeneration. The Bureau maintains the collections in its genebank.

Tables 3 and 4 present major agroforestry tree species (exotic and indigenous collections at the National Genebank in India). Table 5 lists Tree Genomics-focused MPTS at NBPGR, New Delhi.

Table 3. List of available tree genetic resources at different ICAR, ICFRE and allied centers in India

\begin{tabular}{|c|c|c|c|c|}
\hline S.No. & $\begin{array}{l}\text { Name of } \\
\text { the } \\
\text { Institute }\end{array}$ & $\begin{array}{ll}\text { Name of the } \\
\text { species }\end{array}$ & $\begin{array}{l}\text { Number of } \\
\text { germplasms }\end{array}$ & $\begin{array}{l}\text { Details of research } \\
\text { conducted }\end{array}$ \\
\hline \multirow[t]{3}{*}{1} & \multirow[t]{3}{*}{$\begin{array}{l}\text { CAFRI, } \\
\text { Jhansi } \\
(\text { ICAR) }\end{array}$} & $\begin{array}{l}\text { Neem (Azadirachta } \\
\text { indica) }\end{array}$ & 170 & $\begin{array}{l}\text { Genetic variability } \\
\text { through morphological } \\
\text { traits, kernel yield, oil } \\
\text { content and azadirachtin } \\
\text { content estimation, DNA } \\
\text { extraction protocol } \\
\text { optimization }\end{array}$ \\
\hline & & $\begin{array}{l}\text { Subabul (Leucaena } \\
\text { species) }\end{array}$ & 33 & $\begin{array}{l}\text { Fodder quality } \\
\text { assessment, molecular } \\
\text { genetic diversity and } \\
\text { wood properties studies }\end{array}$ \\
\hline & & $\begin{array}{l}\text { North Indian } \\
\text { Rosewood } \\
\text { (Dalbergia sissoo) }\end{array}$ & 14 & $\begin{array}{l}\text { Genetic variability } \\
\text { through morphological } \\
\text { traits, early abiotic stress } \\
\text { tolerance (drought and } \\
\text { waterlogging stress) }\end{array}$ \\
\hline
\end{tabular}




\begin{tabular}{|c|c|c|c|c|}
\hline & & $\begin{array}{l}\text { Malabar } \quad \text { neem } \\
\text { (Melia dubia) }\end{array}$ & 02 & $\begin{array}{l}\text { Germplasm collection } \\
\text { and evaluation for } \\
\text { industrial traits }\end{array}$ \\
\hline \multirow[t]{3}{*}{2} & \multirow[t]{3}{*}{$\begin{array}{l}\text { IIHR, } \\
\text { Bangalore } \\
\text { (ICAR) }\end{array}$} & $\begin{array}{l}\text { Curry leaf (Murraya } \\
\text { koenigii) }\end{array}$ & 100 & $\begin{array}{l}\text { Morphological } \\
\text { characterization is done } \\
\text { at } 1 \text { year after planting, } \\
\text { initiated work on } \\
\text { development of SSR } \\
\text { markers for this species } \\
\text { and Carotenoids, } \\
\text { Flavonoids, Ascorobic } \\
\text { acids, alkaloids, Phenols } \\
\text { are being estimated }\end{array}$ \\
\hline & & $\begin{array}{l}\text { Tamarind } \\
\text { (Tamarindus indica) }\end{array}$ & 460 & $\begin{array}{l}\text { In situ evaluation and } \\
\text { total sugars and acidity } \\
\text { has been assessed in } \\
150 \text { genotypes }\end{array}$ \\
\hline & & $\begin{array}{ll}\text { Jamun } & \text { (Syzygium } \\
\text { cumini) } & \end{array}$ & 95 & $\begin{array}{l}28 \text { accessions done at } \\
\text { flowering and fruit set (4- } \\
5 \text { Years) as per the DUS } \\
\text { parameters, developed } \\
\text { SSR markers and } \\
\text { presently work on } \\
\text { molecular } \\
\text { characterization and } \\
\text { diversity analysis, } 34 \\
\text { accessions, } \\
\text { biochemical parameters } \\
\text { like anthocynin, Phenols, } \\
\text { DPPH, FRAP has been }\end{array}$ \\
\hline
\end{tabular}




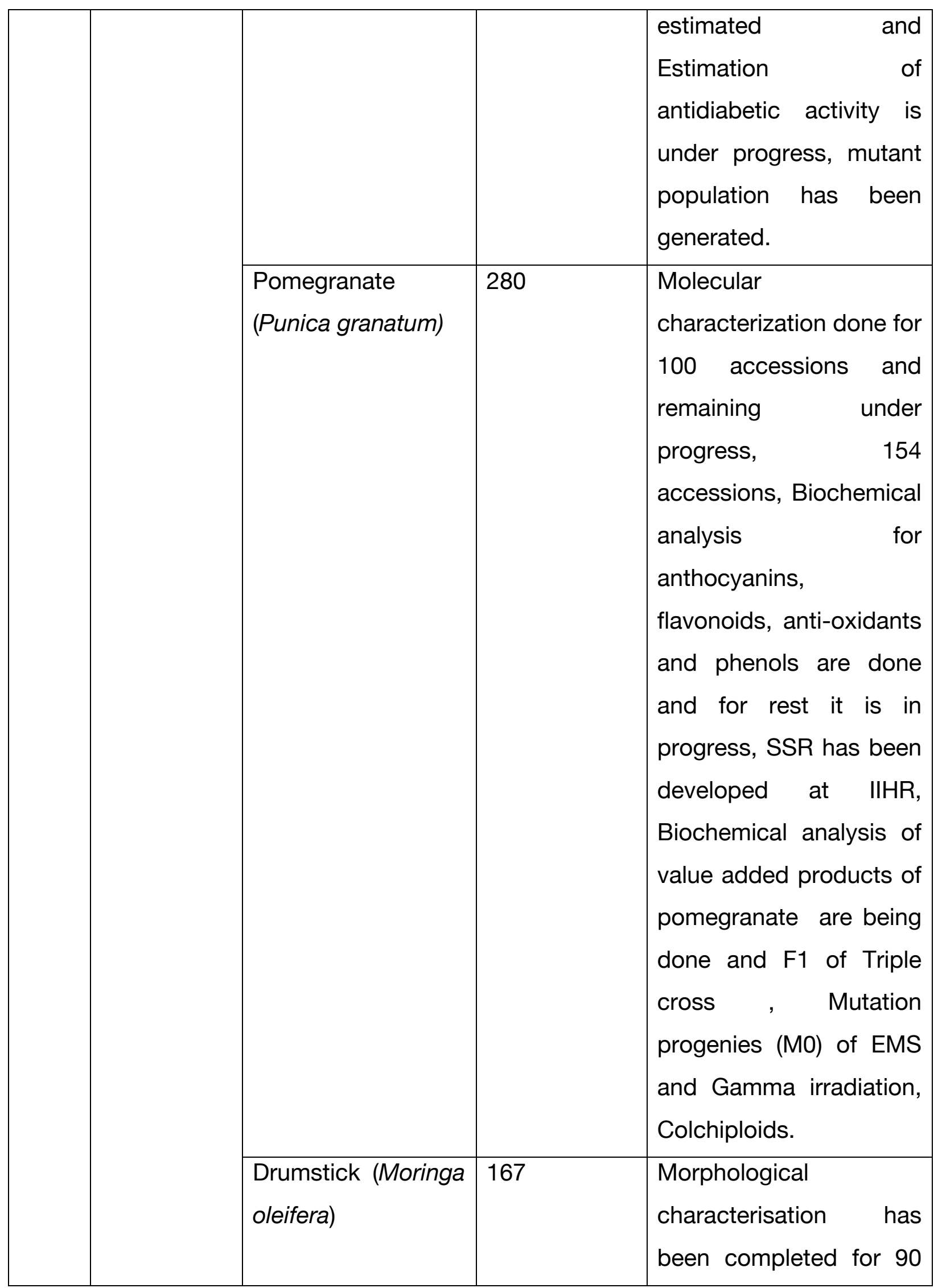




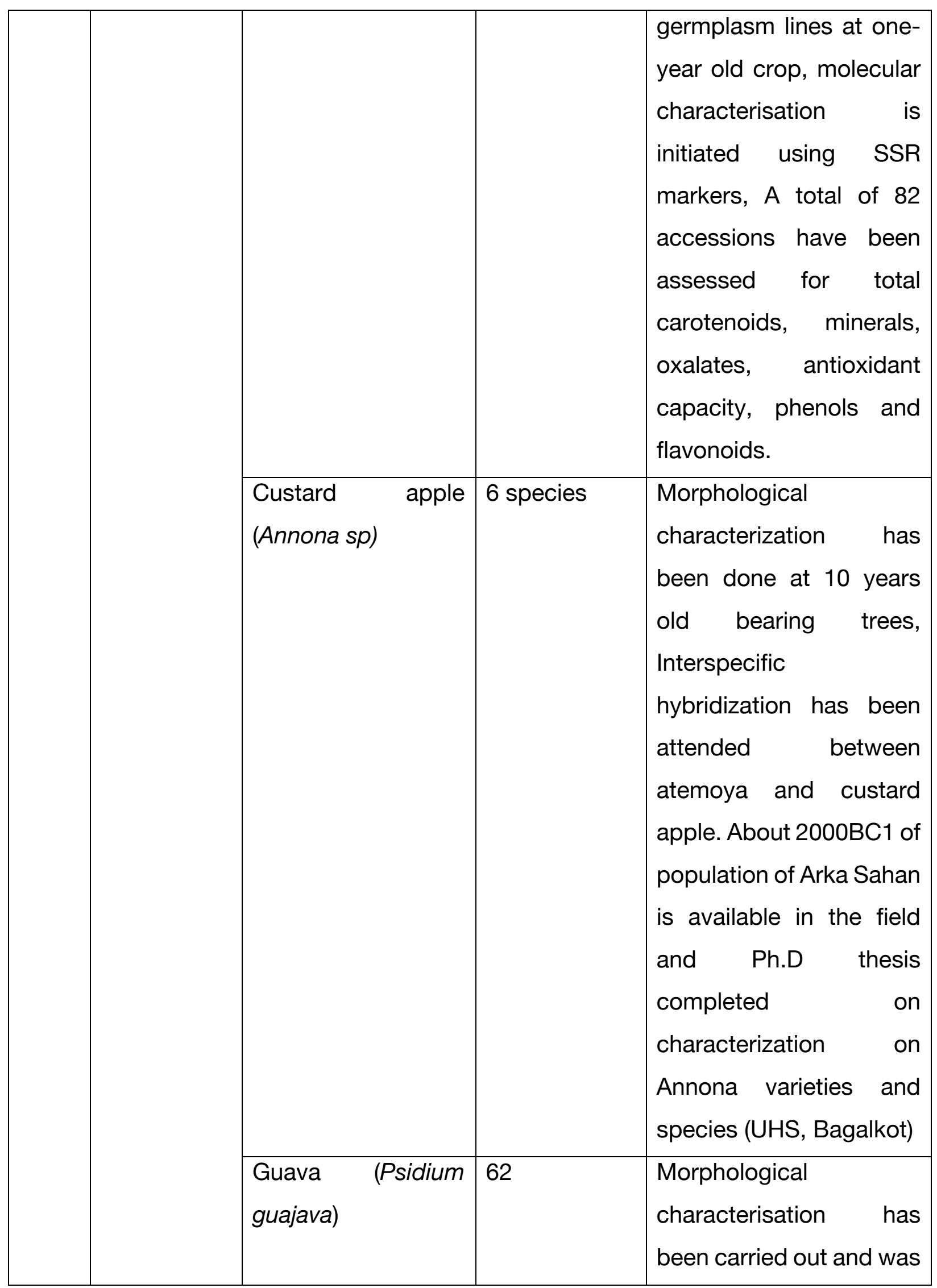




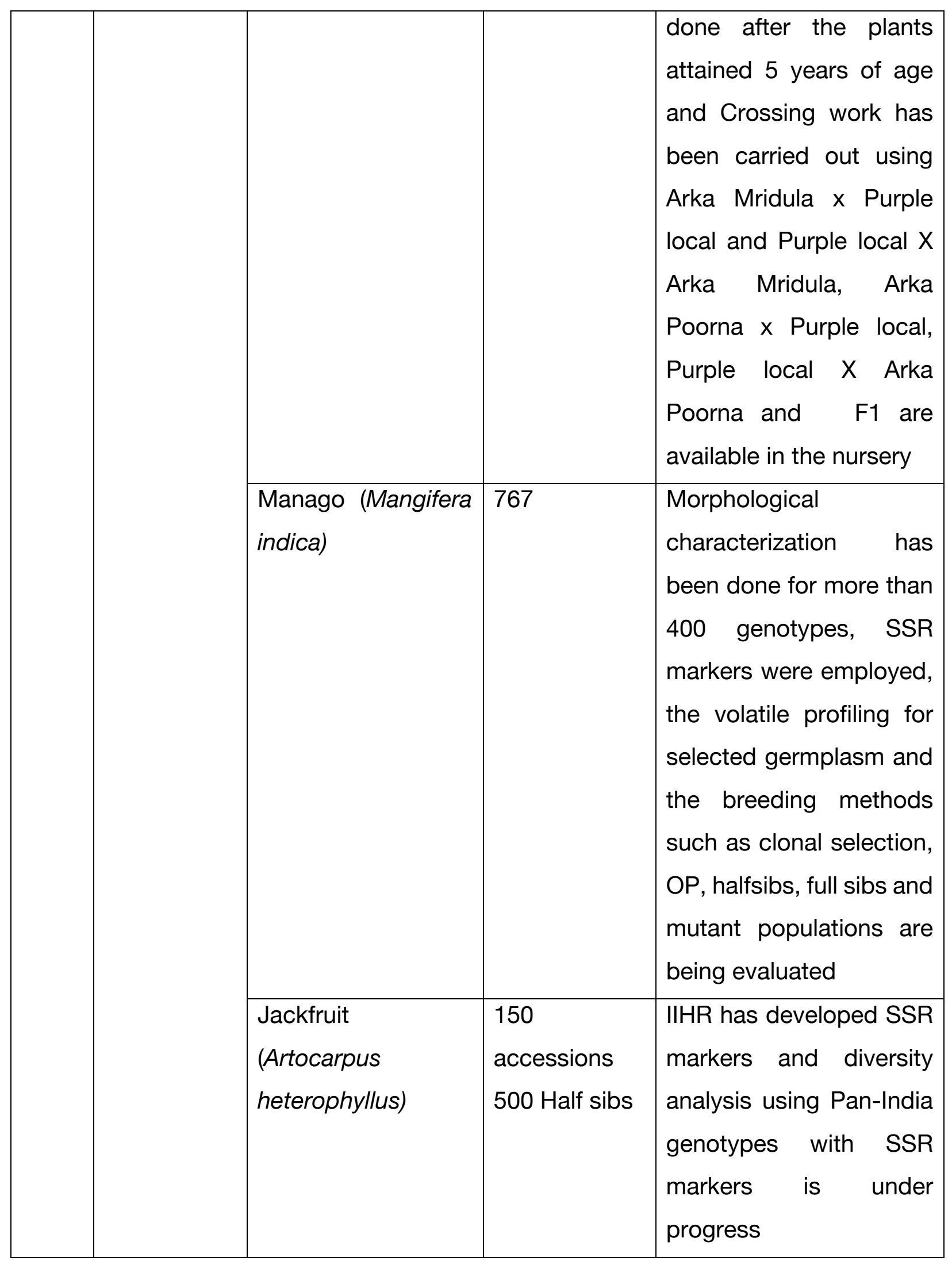




\begin{tabular}{|c|c|c|c|c|}
\hline 3 & $\begin{array}{l}\text { IFGTB, } \\
\text { Coimbatore }\end{array}$ & $\begin{array}{l}\text { Eucalyptus } \\
\text { tereticornis and } E \text {. } \\
\text { camaldulensis }\end{array}$ & $\begin{array}{l}400 \text { including } \\
\text { clones, half } \\
\text { sib, full sib } \\
\text { and } \\
\text { provenances }\end{array}$ & $\begin{array}{l}\text { Different levels of } \\
\text { morphological } \\
\text { characterization have } \\
\text { been carried out. Some } \\
\text { of the clones were } \\
\text { characterized for DUS } \\
\text { descriptors development } \\
\text { and IFGTB is the DUS } \\
\text { testing centre for } \\
\text { Eucalypts, Wood } \\
\text { characterization like } \\
\text { lignin and cellulose } \\
\text { content were estimated, } \\
\text { RAPD, ISSR, AFLP, } \\
\text { SSRs and SNP markers } \\
\text { were used since the year } \\
\text { 2000, like } \\
\text { characterization and cellulose } \\
\text { lignin and } \\
\text { content were estimated, } \\
\text { F2, back cross or any } \\
\text { segregating generation, } \\
\text { mapping population etc } \\
\text { is available. }\end{array}$ \\
\hline & & $\begin{array}{l}\text { Casuarina } \\
\text { junghuhniana }\end{array}$ & 5 Clones & $\begin{array}{l}\text { IFGTB has released five } \\
\text { superior windbreak tree } \\
\text { varieties of Casuarina } \\
\text { junghuhniana viz. IFGTB- } \\
\text { WBC-1, IFGTB-WBC-2, } \\
\text { IFGTB-WBC-3, IFGTB- }\end{array}$ \\
\hline
\end{tabular}




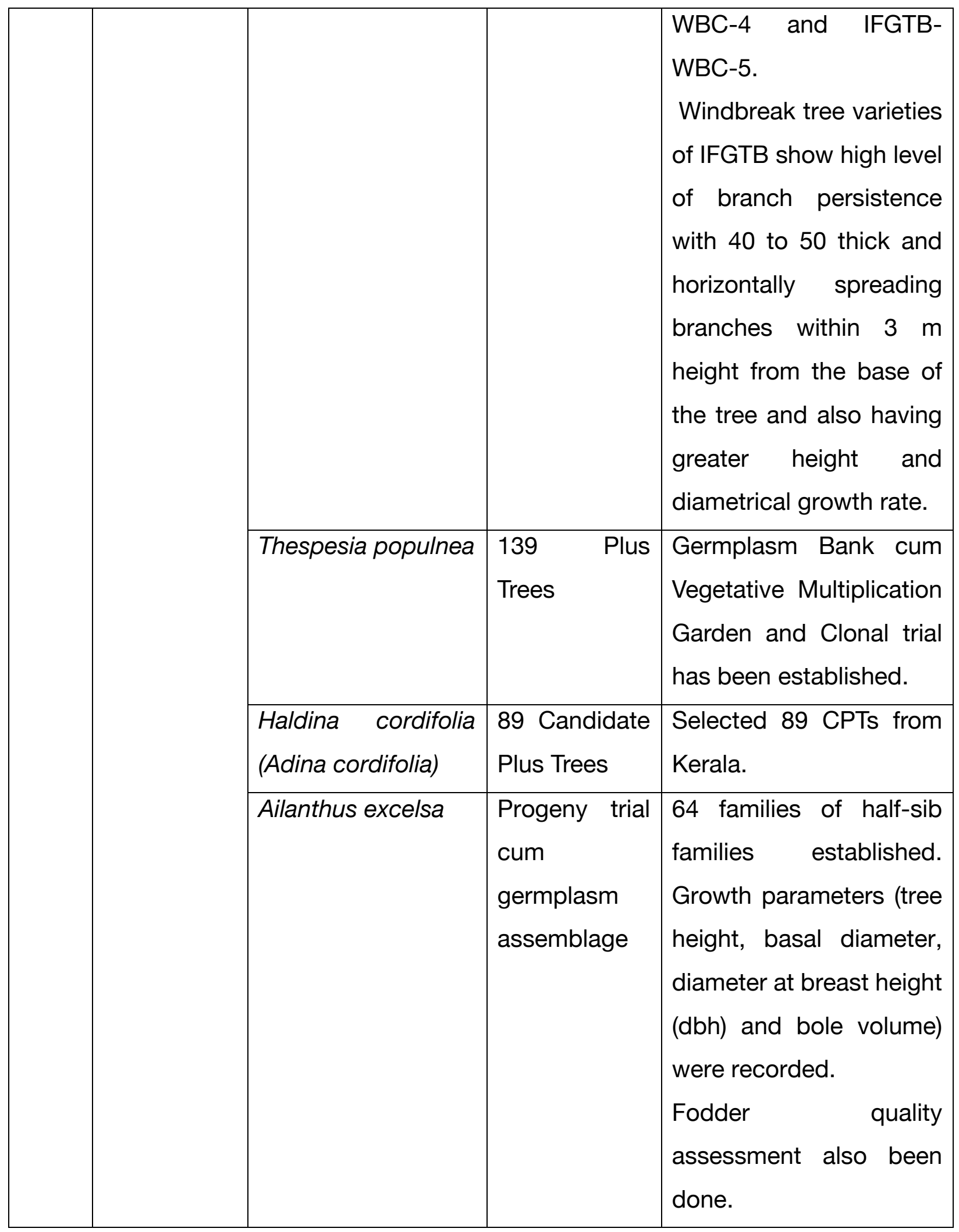




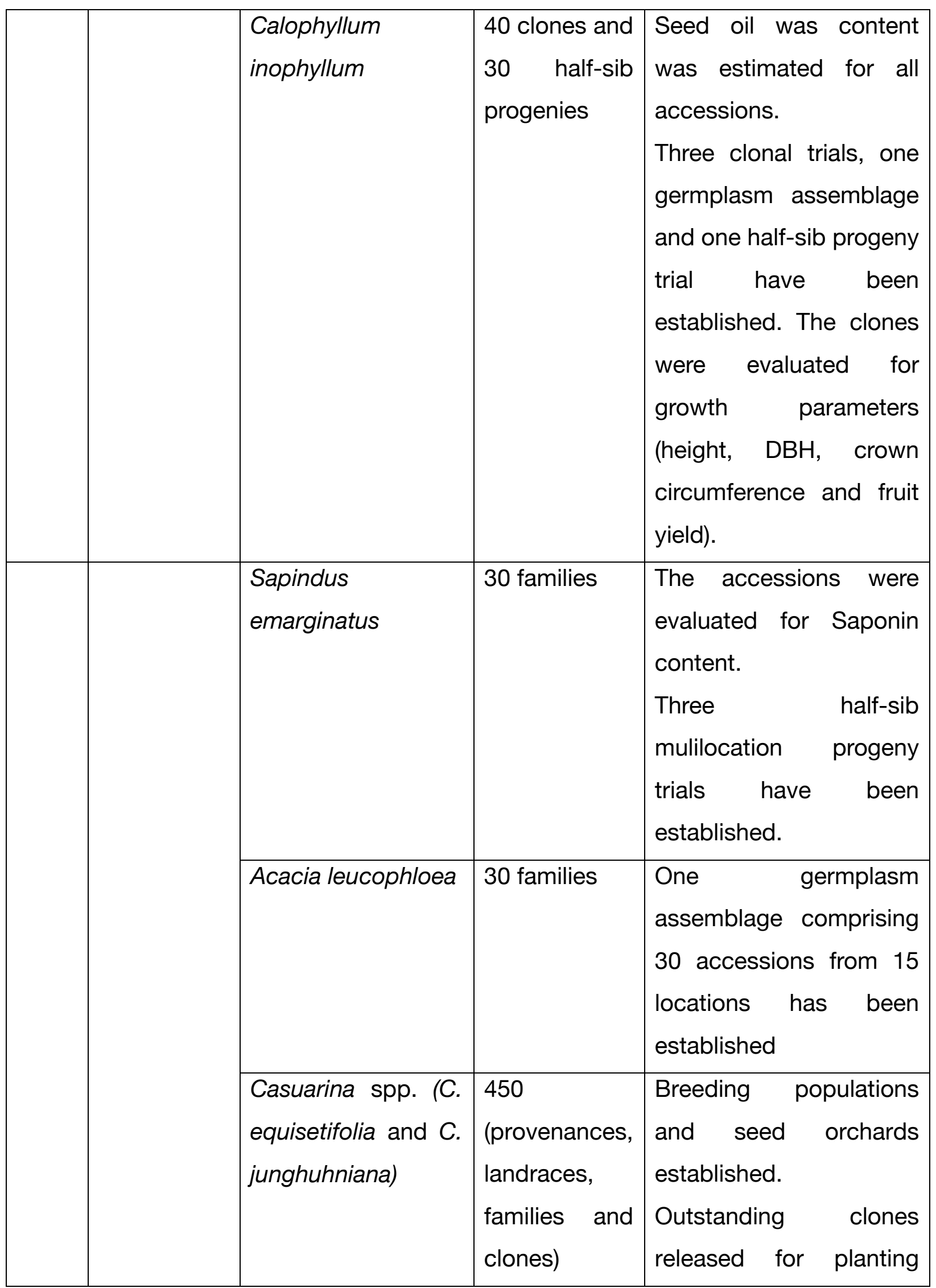




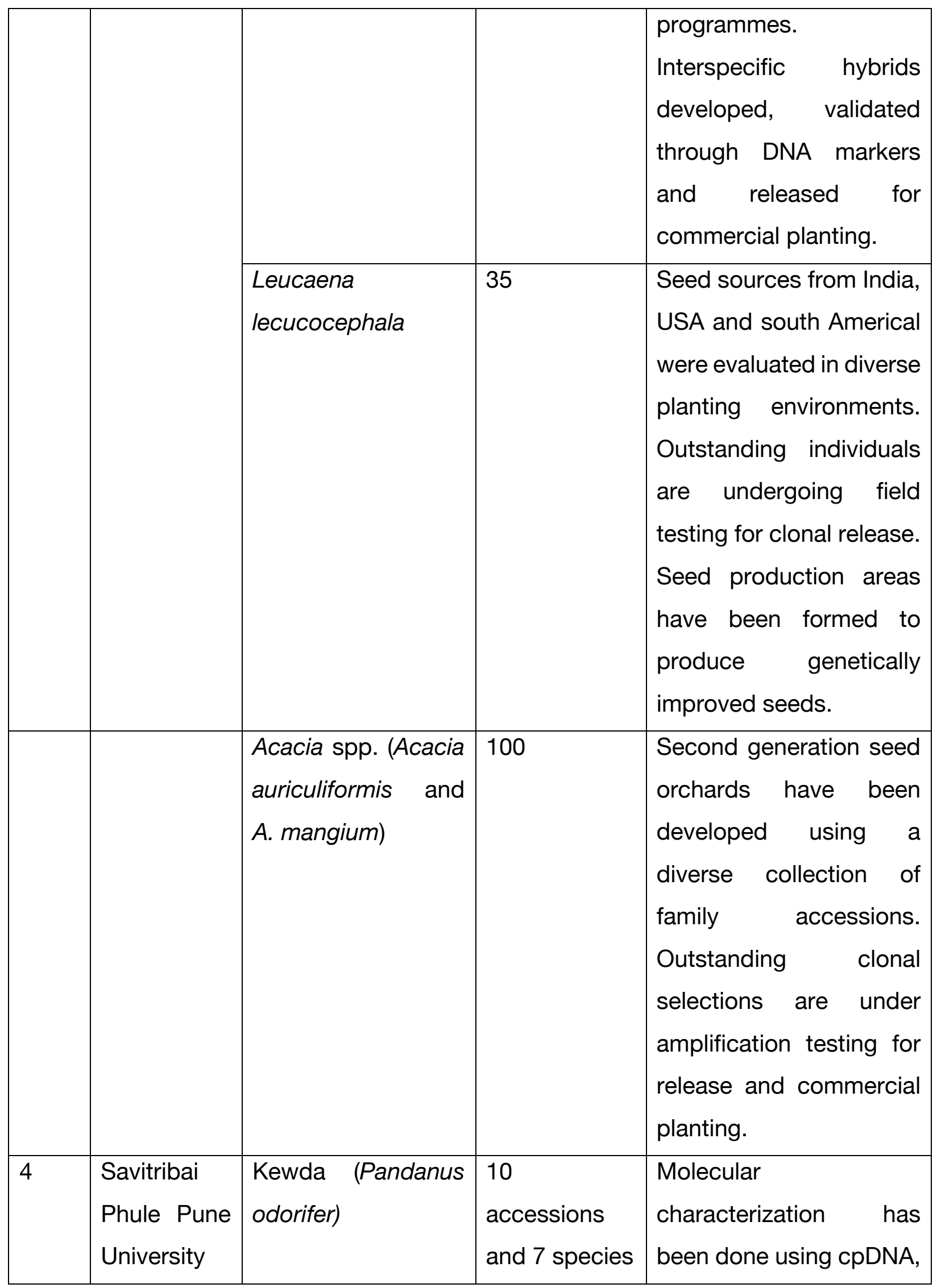




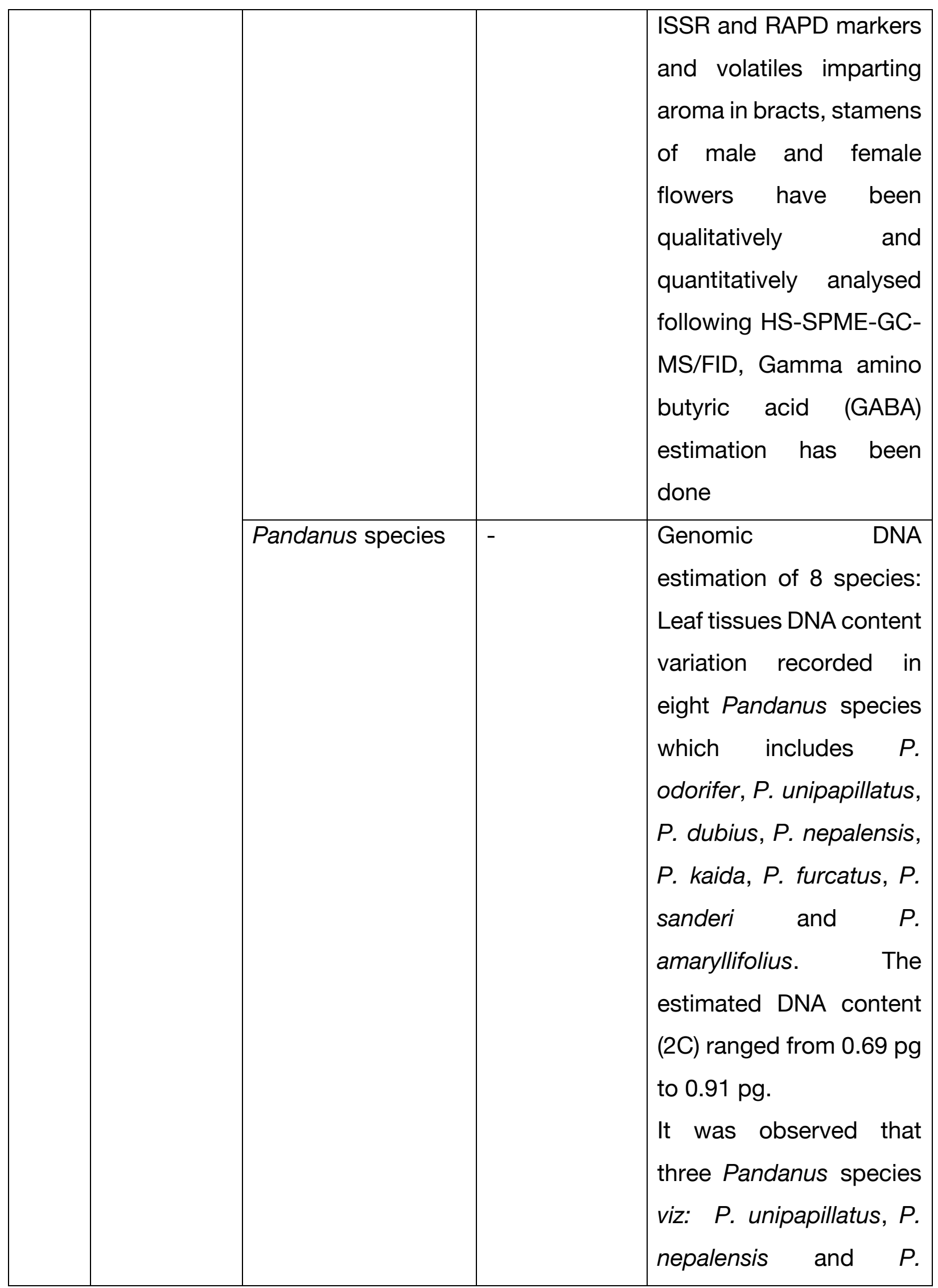




\begin{tabular}{|c|c|c|c|c|}
\hline & & & & 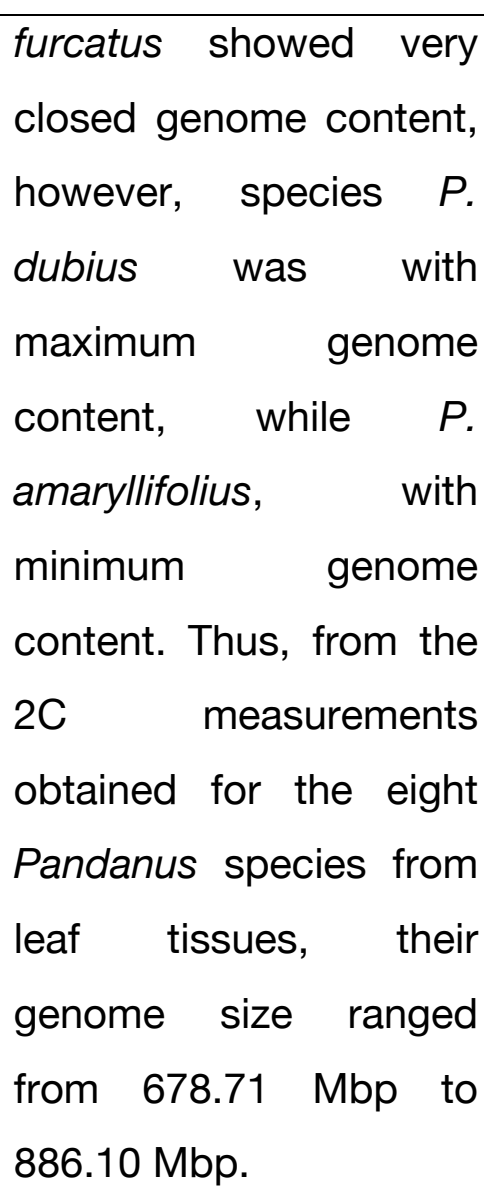 \\
\hline 5 & $\begin{array}{l}\text { ICAR } \\
\text { Research } \\
\text { Complex, } \\
\text { Tripura }\end{array}$ & $\begin{array}{l}\text { Acacia } \\
\text { auriculiformis } \\
\text { (Akashmoni), } \\
\text { Morus alba (Tut), } \\
\text { Leucaena } \\
\text { leucocephala } \\
\text { (Subabul), Dalbergia } \\
\text { sissoo (Shisam), } \\
\text { Gliricidia maculate } \\
\text { (gliricidia), } \\
\text { Azadirachta indica } \\
\text { (Neem), }\end{array}$ & $\begin{array}{l}\text { Each species } \\
\text { one } \\
\text { germplasms } \\
\text { is available }\end{array}$ & $\begin{array}{l}\text { Growth parameters (tree } \\
\text { height, basal diameter, } \\
\text { diameter at breast height } \\
\text { (dbh) and bole volume) } \\
\text { were recorded. The data } \\
\text { were recorded for the } \\
\text { age of } 8 \text { and } 16 \text { years for } \\
\text { all the species } \\
\text { mentioned in the table. }\end{array}$ \\
\hline
\end{tabular}




\begin{tabular}{|c|c|c|c|c|}
\hline & & $\begin{array}{l}\text { Michelia } \\
\text { champakca } \\
\text { (Champa), } \\
\text { Eucalyptus hybrid } \\
\text { (Safeda), Tectona } \\
\text { grandis (Teak), } \\
\text { Gmelina arborea } \\
\text { (Gamahar), } \\
\text { Samania saman } \\
\text { (Raintree) Albizzia } \\
\text { procera } \\
\text { (White sirish) }\end{array}$ & & \\
\hline \multirow[t]{2}{*}{6} & \multirow{2}{*}{$\begin{array}{l}\text { NEH } \\
\text { Region, } \\
\text { Meghalaya } \\
\text { (ICAR) }\end{array}$} & Parkia roxburghii & $\begin{array}{l}7 \\
\text { provenances }\end{array}$ & $\begin{array}{l}\text { Morphological } \\
\text { characterization done }\end{array}$ \\
\hline & & $\begin{array}{l}\text { Jatropha (Jatropha } \\
\text { curcas L.) }\end{array}$ & 10 & $\begin{array}{l}\text { Seed oil content was } \\
\text { estimated (28.79\% - } \\
42.89 \%) \text { Fatty acid } \\
\text { profile of } 5 \text { germplasm } \\
\text { was analysed. Bio- } \\
\text { chemical } \\
\text { characterization with } \\
\text { special reference to } \\
\text { bioactivity guided } \\
\text { screening of different } \\
\text { plant parts to evolve } \\
\text { genotype/varieties of } \\
\text { phytoceutical } \\
\text { importance. }\end{array}$ \\
\hline
\end{tabular}




\begin{tabular}{|c|c|c|c|c|}
\hline 7 & $\begin{array}{l}\text { TFRI, } \\
\text { Jabalpur } \\
\text { (ICFRE) }\end{array}$ & Tectona grandis & 40 clones & $\begin{array}{l}40 \text { grafted clones of teak } \\
\text { from all over India are } \\
\text { assembled as CSO. }\end{array}$ \\
\hline & & Dalbergia latifolia & 12 families & $\begin{array}{l}\text { Progeny Trial has been } \\
\text { established using half- } \\
\text { sib seeds from } 12 \\
\text { families. }\end{array}$ \\
\hline & & $\begin{array}{l}\text { Pterocarpus } \\
\text { marsupium }\end{array}$ & 25 families & $\begin{array}{l}\text { Progeny Trial has been } \\
\text { established using half- } \\
\text { sib seeds from } 25 \\
\text { families. }\end{array}$ \\
\hline & & Litsea glutinosa & $\begin{array}{l}90 \\
\text { accessions }\end{array}$ & $\begin{array}{l}\text { Germplasm Bank has } \\
\text { been established using } \\
90 \text { accessions from } 10 \\
\text { locations. }\end{array}$ \\
\hline & & $\begin{array}{l}\text { Bamboo spp. } \\
\text { (Bambusa vulgaris } \\
\text { var. green, B. } \\
\text { bambos, B.tulda, } \\
\text { Dendrocalamus } \\
\text { strictus). }\end{array}$ & 4 species & $\begin{array}{l}\text { Germplasm Bank of } 4 \\
\text { species of bamboo has } \\
\text { been established. }\end{array}$ \\
\hline 8 & $\begin{array}{l}\text { CCS, Hisar } \\
\text { Haryana }\end{array}$ & Melia composite & 24 plus trees & $\begin{array}{l}\text { Molecular genetic } \\
\text { diversity through RAPD } \\
\text { markers. The cluster } \\
\text { analysis indicated two } \\
\text { distinct clusters, one } \\
\text { comprising of MCP10 } \\
\text { and MCP11 while the } \\
\text { second cluster included }\end{array}$ \\
\hline
\end{tabular}




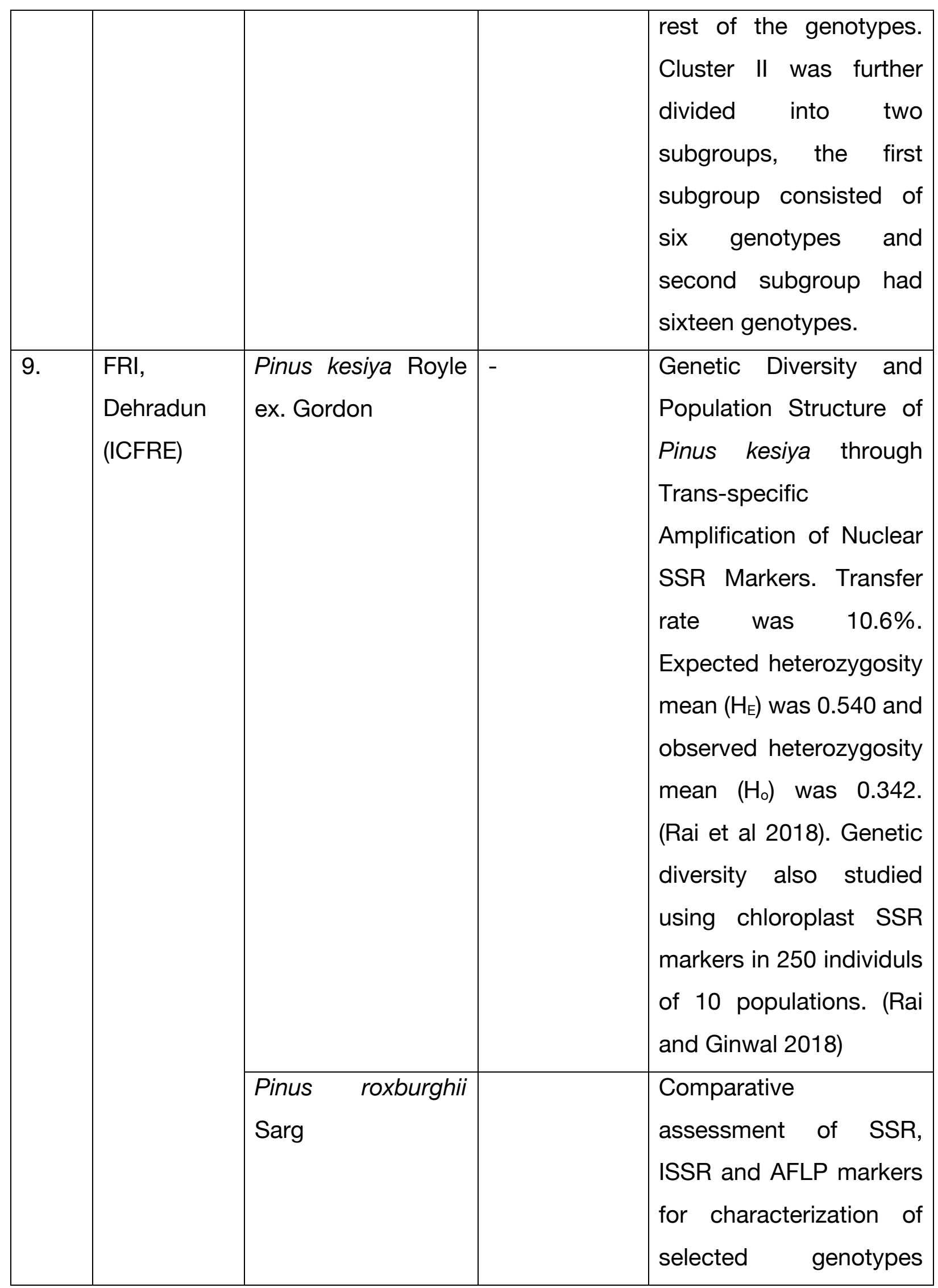




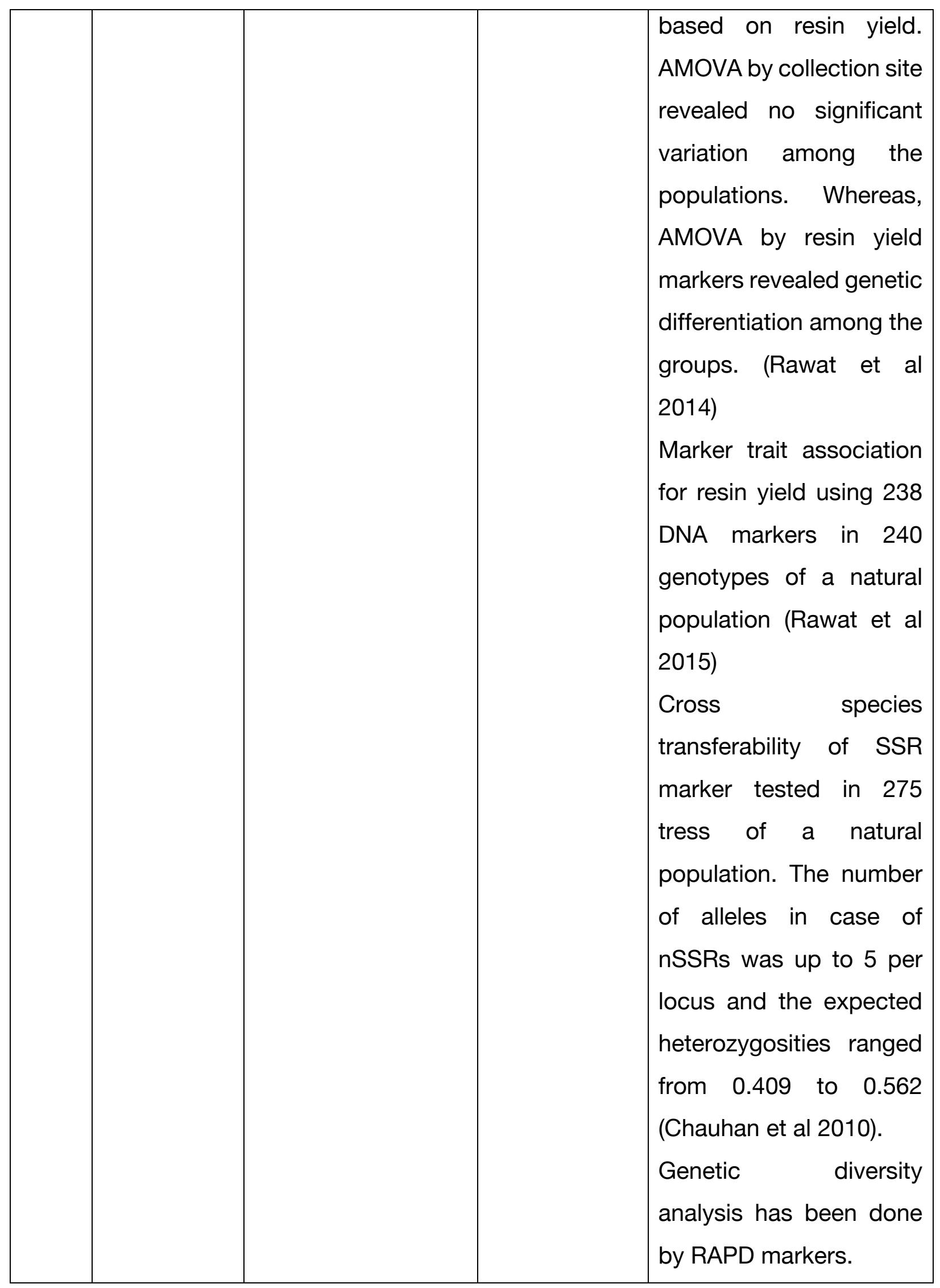




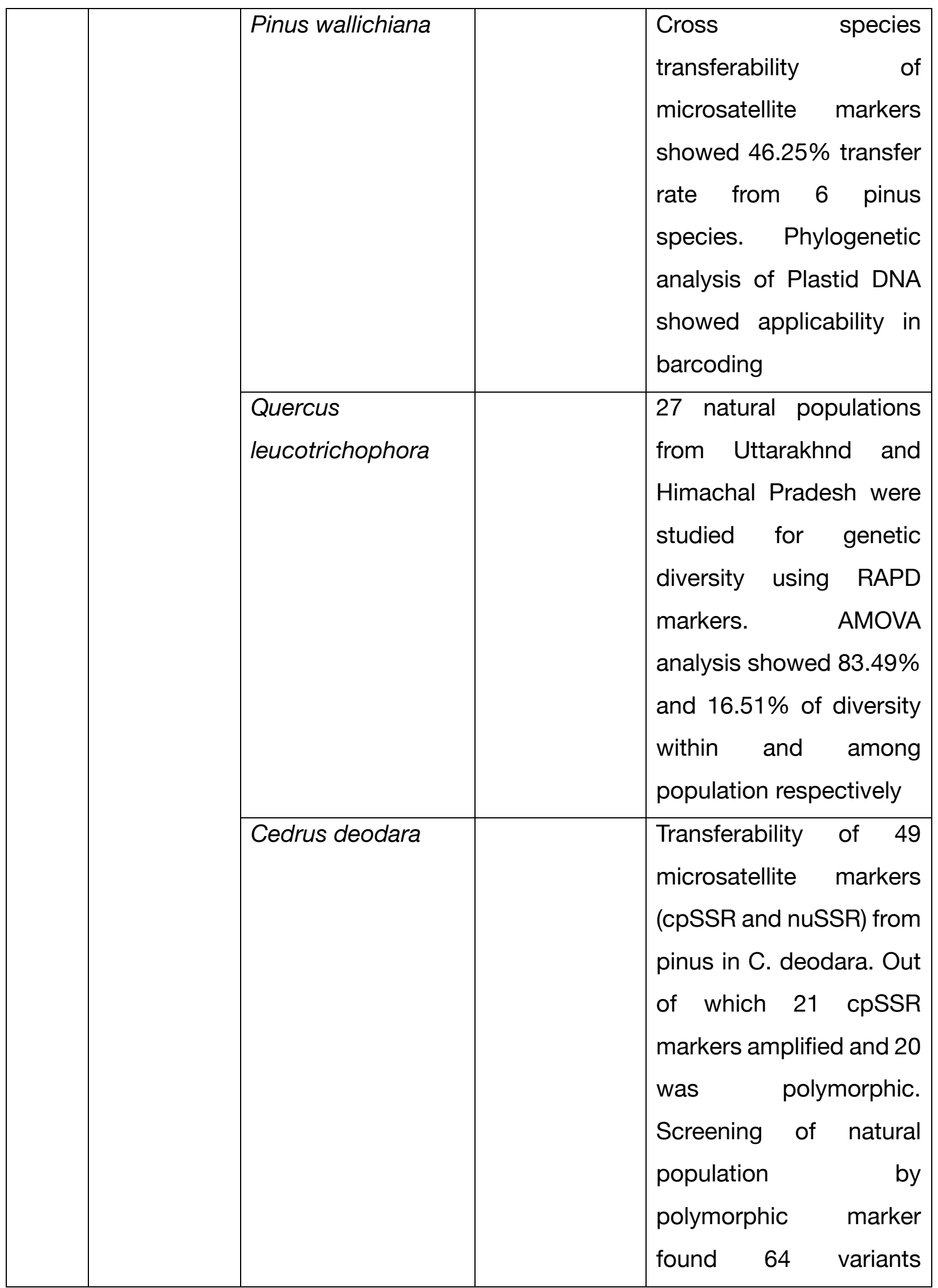




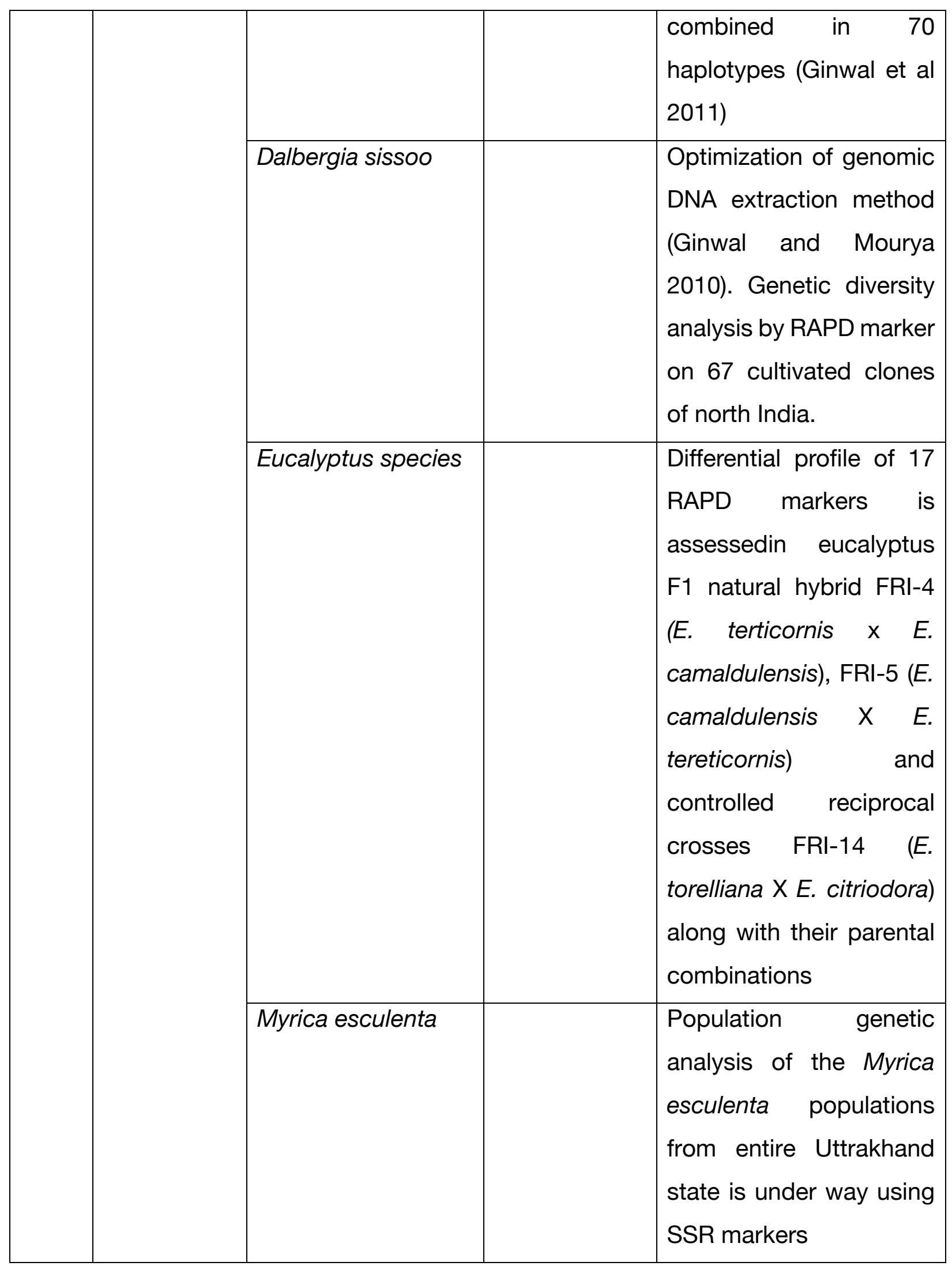




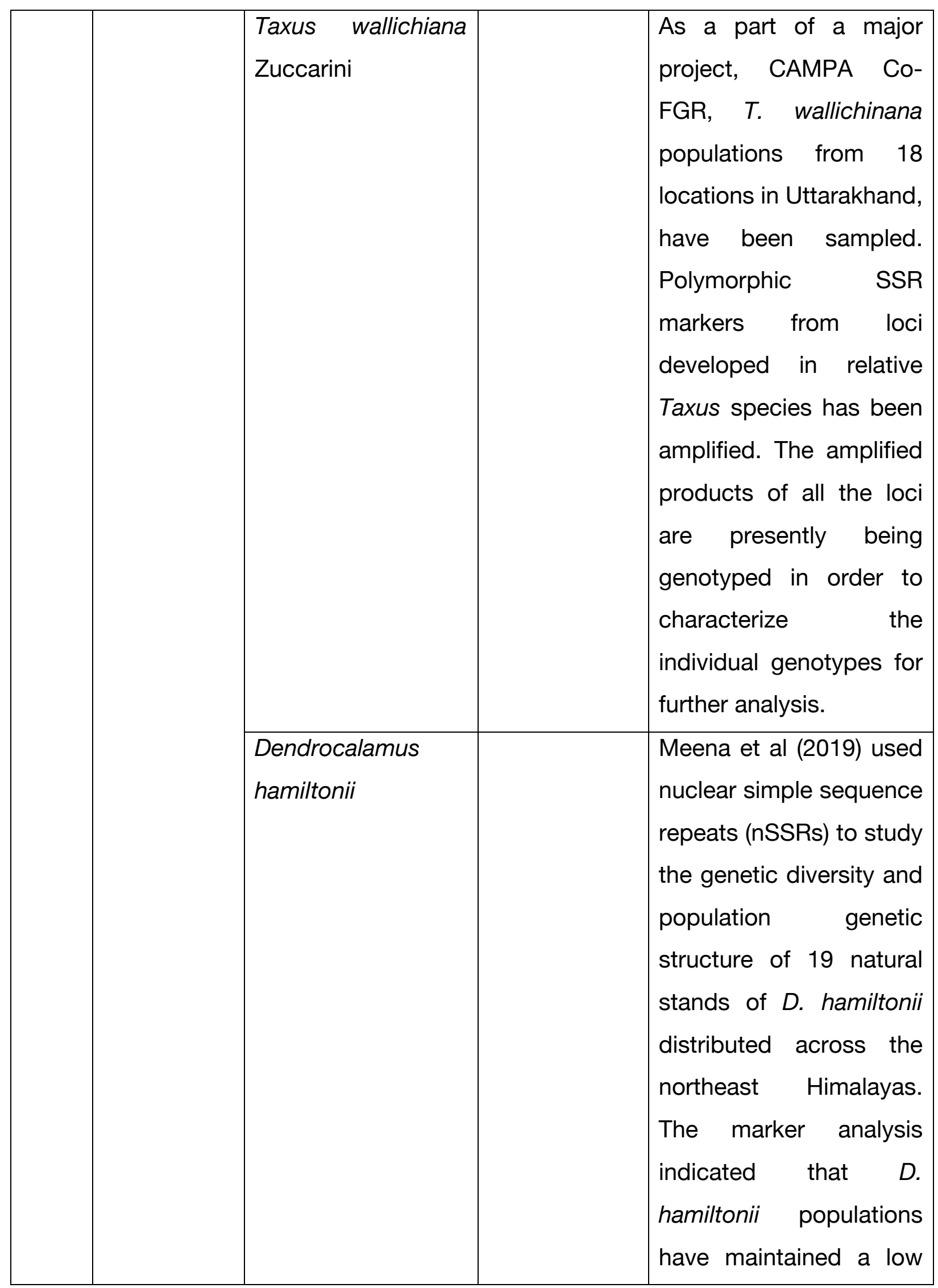




\begin{tabular}{|c|c|c|c|c|}
\hline & & & & $\begin{array}{l}\text { level of genetic diversity } \\
(h=0.175, \quad l=0.291) \quad \text { in } \\
\text { northeastern region of } \\
\text { India. }\end{array}$ \\
\hline \multirow[t]{3}{*}{10} & \multirow[t]{3}{*}{$\begin{array}{l}\text { CRIDA, } \\
\text { Hyderabad } \\
(\text { ICAR) }\end{array}$} & Pongamia pinnata & $\begin{array}{l}39 \\
\text { accessions }\end{array}$ & $\begin{array}{l}\text { Accessions of Pongamia } \\
\text { were collected from } \\
\text { Southern India } \\
\text { Growth parameters (tree } \\
\text { height, and diameter at } \\
\text { breast height (dbh)) were } \\
\text { recorded and } \\
\text { established in field. } \\
\text { Genotype versus year } \\
\text { interaction of pod and } \\
\text { seed mass and stability } \\
\text { of Pongamia pinnata } \\
\text { families in a semi-arid } \\
\text { region was studied for } \\
\text { biofuel parameters. }\end{array}$ \\
\hline & & $\begin{array}{l}\text { Leucaena } \\
\text { leucocephala }\end{array}$ & $\begin{array}{l}32 \\
\text { accessions }\end{array}$ & $\begin{array}{l}\text { Germplasm lines of } \\
\text { advanced breeding } \\
\text { material were collected } \\
\text { and maintained at field. }\end{array}$ \\
\hline & & Tamarindus indica & $\begin{array}{l}40 \\
\text { accessions }\end{array}$ & $\begin{array}{l}\text { Germplasm of released } \\
\text { varieties from southern } \\
\text { India were maintained at } \\
\text { field and studied for fruit } \\
\text { and growth characters }\end{array}$ \\
\hline
\end{tabular}




\begin{tabular}{|c|c|c|c|c|}
\hline 11 & $\begin{array}{l}\text { ICAR-CITH, } \\
\text { Srinagar (J } \\
\& \mathrm{~K})\end{array}$ & Juglans regia & $\begin{array}{l}136 \\
\text { accessions }\end{array}$ & 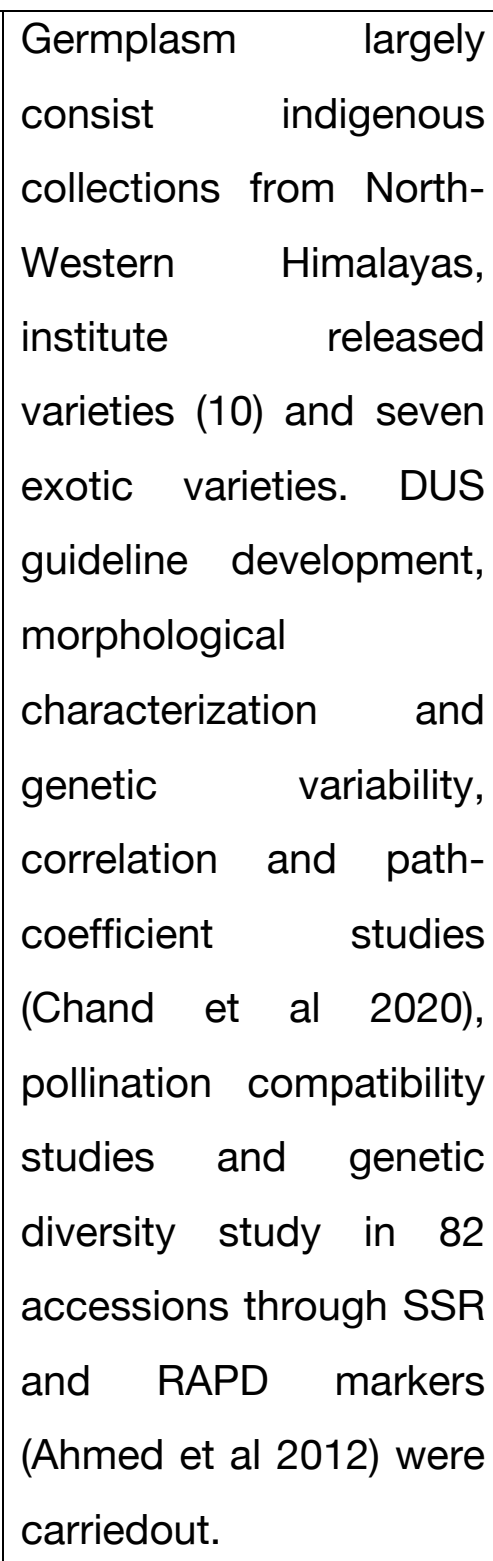 \\
\hline
\end{tabular}

Table 4. Exotic collection of major agroforestry species in the National Gene Bank of India

\begin{tabular}{|l|l|l|}
\hline S. no. & Crop/Species & No. of accessions \\
\hline 1 & Sesbania & 16 \\
\hline 2 & Sesbania rostrata & 9 \\
\hline 3 & Prickly sesban & 8 \\
\hline 4 & Sesbania cannabina & 8 \\
\hline
\end{tabular}




\begin{tabular}{|l|l|l|}
\hline 5 & Sesbania aculeata & 6 \\
\hline 6 & Common Sesban & 3 \\
\hline 7 & Sesbania sesban & 3 \\
\hline 8 & Sesbania tetraptera & 1 \\
\hline 9 & Simarouba & 1 \\
\hline 10 & Simarouba glauca & 1 \\
\hline
\end{tabular}

Table 5. Indigenous collection major agroforestry species inthe national gene bank of India

\begin{tabular}{|c|c|c|}
\hline S.No. & Crop name/Botanical name & Total no of accessions \\
\hline 1 & Sesbania & 649 \\
\hline 2 & Acacia & 239 \\
\hline 3 & Albizia & 166 \\
\hline 4 & Prosopis cineraria & 48 \\
\hline 5 & Tamarindus indica & 45 \\
\hline 6 & Salvadora oleoides & 30 \\
\hline 7 & Bauhinia spp. & 19 \\
\hline 8 & Dalbergia sissoo & 19 \\
\hline 9 & Semecarpus anacardium & 18 \\
\hline 10 & Butea monosperma & 17 \\
\hline 11 & Sesbania cannabina & 17 \\
\hline 12 & Erythrina indica & 15 \\
\hline 13 & Sterculia & 15 \\
\hline 14 & Pterocarpus marsupium & 13 \\
\hline 15 & Bauhinia variegata & 13 \\
\hline 16 & Anogeissus spp. & 12 \\
\hline 17 & Decalepsis & 10 \\
\hline 18 & Pterocarpus santalinus & 9 \\
\hline 19 & Nyctanthes arbor-tristis & 8 \\
\hline
\end{tabular}


Table 6. Tree genomics focused multipurpose tree species (MPTS) at ICARNBPGR, New Delhi, India

\begin{tabular}{|l|l|l|}
\hline S.No. & Name of species & No. of accessions \\
\hline 1 & Prosopis cineraria & 48 \\
\hline 2 & Tamarindus indica & 45 \\
\hline 4 & Moringa oleifera & 8 \\
\hline 5 & Dalbergia sissoo & 6 \\
\hline 6 & Commiphora wightii & 3 \\
\hline 7 & Melia dubia & 2 \\
\hline 8 & Pchleichera oleosa & 2 \\
\hline 9 & Casuarina equisetifolia & 2 \\
\hline 10 & Punica granatum & 2 \\
\hline 11 & Syzygium cumini & 1 \\
\hline 12 & Litsea glutinosa & 1 \\
\hline 13 & Tectona grandis & 1 \\
\hline 14 & Azadirachta indica & 1 \\
\hline
\end{tabular}

\section{INTERNATIONAL EFFORTS TOWARDS GENERATING GENOMICS RESOURCES FOR AGROFORESTRY TREE SPECIES}

Different aspects of application-oriented translational genomics research have become extremely specialized due to different skill-sets needed to address problems associated with each part. Thus, it can be observed that many such efforts are following the consortium- or group-type approach for developing genomics resources. Some of the well-known international consortia are avocado genome consortium (https://www.fabinet.up.ac.za/index.php/arp-projects/avocado-genome-consortium), mango genome sequencing consortia in India, Australia and USA (Kuhn et al 2019; Singh et al 2018), and informal groups working on breadfruit, jackfruit, coffee, cacao, etc. Another international multi-crop consortium promoted by World Agroforestry (ICRAF) is the African Orphan Crops Consortium. 


\subsection{African Orphan Crops Consortium}

The African Orphan Crops Consortium (AOCC, http://africanorphancrops.org/) is a consortium of public-private partners that was built to develop genomics resources for Africa's under-utilized, under-researched, and under-funded food crops and trees (Hendre et al 2019; Jamnadass et al 2020). The AOCC framework provides a robust skeleton that can be used to build a similar multi-tree species consortium in India. Various functional aspects of the consortium have been partitioned into five broader areas where the 27 partners fall into one or more roles (http://africanorphancrops.org/partners-and-network/).

The consortium relies on its partners who bring an interdependent web of services and tools on board, thus ensuring sustainability. The consortium has already sequenced five tree species (Moringa oleifera, Faidherbia albida, Sclerocarya birrea, Artocarpus heterophyllus, Artocarpus altilis) and is ready with genomic data for nine more tree species (Vitellaria paradoxa, Annona cherimola, Vangueria madagascariensis, Balanites aegyptica, Tamarindus indica, Irvingia gabonensis, Passiflora edulis, Annona reticulate, and Ricinodendron heudelotii).

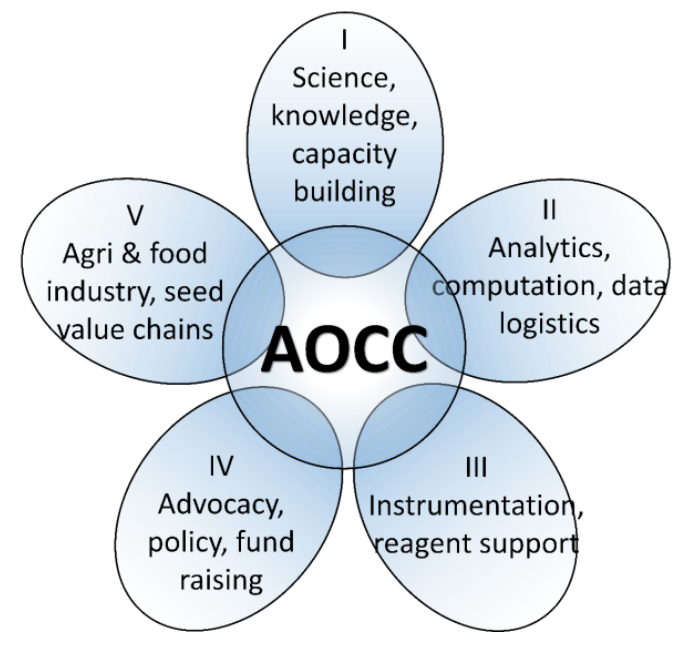

Figure 1: Five major areas of partnership under the AOCC (Hendre et al 2019) 


\subsection{Indian partnership on tree genomics and improvement}

India has a huge potential for development and application of modern tools, especially high throughput genomics and phenomics due to a strong base of supporting genomics and bioinformatics infrastructure in both the public and private sectors. As majority of these tools are generated for annual crops, the perennial crops need a major boost to reap the benefits and see tangible benefits to the farmers. Here, we propose formation of an India-centric partnership to achieve these goals along the lines of the AOCC, where a diverse and broad partnership would provide a strong foundation and functional complementaries. Thus, the following major groups of partners are being proposed for a possible Indian partnership on tree genomics and improvement:

1. Advocacy partners: This would constitute government bodies, secretaries from various government departments (Department of Agriculture, Department of Science \& Technology, Department of Bio-Technology, etc.), nodal bodies of universities, vice-chancellors, NGOs, philanthropic organizations to lobby and support the cause.

2. Philanthropic trusts: Philanthropic trusts such as Tata Trust, Infosys Foundation, Azim Premji Foundation, MS Swaminathan Research Foundation will be vital for cash support to run such an organization.

\section{Research institutes:}

a. Indian Council of Agricultural Research (ICAR): India has one of the largest and oldest national agricultural research systems in the world with several regional/centralized institutes, national-level coordinated programmes, which are working on a number of crops (annuals and trees), some of which are under-utilized. This can provide established processes and methods to conduct part of the above activities like I.1 to I.5. Some national-level organizations like the Indian Agricultural Research institute (IARI) can support activities like II.1 to II.4.

b. Council for Scientific and Industrial Research (CSIR): CSIR has a high potential to help in undertaking some basic research like bioavailability of food nutrients and also capacity to help in systems and synthetic biology 
of these crops. These are some potential areas that could arise after working on these crops.

c. Indian Council of Forestry Research and Education: ICFRE with nine regional research institutes and five centres in different bio-geographical regions of the country is involved in genetic improvement of several forestry tree species and manages genetic resources of tree species for conservation and sustainable utilization. ICFRE-IFGTB is presently involved in generating genomic resources of several indigenous tree species through whole genome and transcriptome sequencing.

d. State Agricultural Universities: India has many agricultural universities and affiliated colleges which have knowledge about local/niche crops through their regional centres and can work alongside ICAR organizations to support activities like I1 to I.5 and to some extent, II.1 to II.4.

e. Others: Other regional and local institutes which work on focused crops or areas.

4. International and national instrumentation-technology partners: This is particularly important for instrumentation necessary for high throughput nutrient analysis, and next-generation sequencing. There are various companies like Illumina, Thermo Fisher Scientific, Oxford Nanopore, PacBio, Affymtrix, LGC, Perkin Elmer, NEB, Roche, etc. which can be approached for in-kind donation or to form a fund to sponsor some activities.

5. International and national data analytics and logistics partners: These partners could offer secured, safe and easy data access, storage and analytics services. Google has already entered into the space of publicly accessible genomics services. Likewise, there will be providers such as Amazon, Microsoft which are also coming with their own offerings. Some local partners are also good at customized data analytics which just require minor tweaking of the analysis pipelines. 
6. Private seed industry: India has a strong seed industry with expertise in seed production, supply chain, distribution and feedback mechanisms. Some of them are MNCs but there are several local seed companies which produce seeds of niche or specialized crops to satisfy regional needs. These can be encouraged to invest in these orphan or new crops, but it may need some state sponsorship until these new crops sustainably settle in the market.

7. Private processed or raw food producers (infant formula, powdered foods, oil producers, vitamin, protein \& health supplements, FMCG products, specialty food supplements, ready-to-eat, food colours etc.): Private sector food industry is always searching for new tastes, delicacies and value-added products and can be roped in during the product profiling stage and trait prioritizations. Nutralite, Amway, Himalaya, ITC, HUL, Ashoka, Tata, etc. are some partners working in this area.

8. Timber, paper and pulp companies: This forms a major beneficiary group of agroforestry-based industries and include national players like Ballarpur Industries, ITC Ltd, Tamilnadu Newsprint \& Papers Limited (TNPL), JK Paper Ltd, etc. Almost all of these have been practicing responsible sourcing of wood and can form a very important group of partners to further the goals of sustainable agroforestry practices.

9. Development agencies, community and farmer's organizations: Various development organizations, NGOs, farmer's groups, local cooperative societies, women's groups, self-help groups and microfinancing groups will be very important for local ground-level operations. These will help in gender balance, youth inclusivity, popularization, demonstrations, agricultural finance, extension, knowledge dissemination and feedback mechanisms. 


\section{SCOPE OF TREE GENOMIC RESEARCH}

Trees are valued sources of food (nuts, vegetables, fruit) pulp, timber, fodder, medicinals, biofuels etc., and play an essential role in $\mathrm{CO}_{2}$ sequestration, biodiversity maintenance and watershed stability, erosion control, host to pollinators, etc. which needs to be deeply understood and improved for meeting the specific demands of present-day challenges. Genomics is among the promising tools that can bring revolutions in future healthcare and environmental protection. The first step is to enrich the tree genomic resources which will help in a deeper understanding of structural and functional genomics. Capturing wide genetic variation residing in natural populations, developing mapping population, molecular markers, gene mapping, transcriptomics, and genome sequencing to identify potential candidate genes involved in biotic, abiotic stresses and quality parameters are the prioritized area in practical tree genomic research in India. Database development, structural and functional genomics will help in dissecting genetic control of various economically important traits of tree species. Population scale studies through comparative genomics, ecological genomics, and quantitative genetics can give a deeper understanding of forest tree populations.

\section{FUTURE PERSPECTIVES}

Assembly and annotation of multiple hardwood tree genomes will facilitate an increase in: (1) functional characterization of genes and gene networks related to tree habit, (2) GWAS and genomic selection investigations and applications, and (3) comparative genomic efforts among various tree species. The rapidly expanding new technologies will add an even greater number of hardwood species to these efforts. The power of comparative genomics will increase our understanding of how these highly dynamic genomes have evolved and resulted in the amazing array of phenotypic diversity found among and within hardwood species.

In sum, most hardwoods are undomesticated long-lived plants that provide many ecological and commercial benefits, whose management, conservation and domestication for economic and ecological purposes will benefit from a set of rich 
genomics resources. Ultimately such resources will favourably impact the pressing problems of climate change, soil and water conservation, bioenergy and biomaterials production, and maintenance of healthy ecosystem functions. The genomic studies in reference to the fruit and nut trees have a wider scope and application to hasten the breeding programme. It will help in identification and characterization of candidate genes and gene families related to important traits viz., tree architecture, yield governing traits like regular bearing, bearing habit, fruit and nut weight, quality traits (fresh and processed fruits), resistance and/or tolerance to biotic and abiotic stresses.

Tree genomics will ease the understanding of phylogenetic structure and introgression of genes from wild relatives for development of climate-smart varieties of fruits and nuts. It has opened up doors for germplasm conservation, characterizations and utilization by use of high-throughput genetic structure analysis throughout wild relatives, land races and commercial cultivars in many fruit crops. Use of genomic tools will help in understanding the genotype-phenotype interactions, discover physiological pathways for nutrient uptake, assimilations, and in synthesis of biomolecules in fruit and nut crops. The breeding for nutrient (iron, zinc, iodine, selenium, vitamin A, etc.)-enriched genotypes in fruit and nut crops is the key through bio-fortification using genome-editing approach like CRISPR/Cas 9 to tackle malnutrition. 


\section{REFERENCES}

[CSRTI] Annual Report 2019. Central Sericultural Research \& Training Institute (CSRTI), Mysore. African Orphan Crops Consortium (AOCC, http://africanorphancrops.org/)

Ahmad I, Bhagat S, Simachalam P, Srivastava RC. 2012. Molecular characterization of Syzygium cuminii (wild jamun) from A\&N Islands. Indian Journal of Horticulture 69(3):306-311

Ahmed N, Mir Jl, Mir RR, Rather NA et al. 2012. SSR and RAPD analysis of genetic diversity in walnut (Juglans regia L.) genotypes from Jammu and Kashmir, India. Physiology and Molecular Biology of Plants 18(2):149-60. doi: 10.1007/s12298-012-0104-z

Akagi T, Shirasawa K, Nagasaki H et al. 2020. The persimmon genome reveals clues to the evolution of a lineage-specific sex determination system in plants. PLoS Genetics 16(2):e1008566. Doi: 10.1371/journal.pgen.1008566

Al-Dous EK, George B, Al-Mahmoud ME et al. 2011. De novo genome sequencing and comparative genomics of date palm (Phoenix dactylifera). Nature Biotechnology 29:521527. doi:10.1038/nbt.1860

Al-Harrasi A, Rehman NU, Khan AL et al. 2018. Chemical, molecular and structural studies of Boswellia species: $\beta$-Boswellic Aldehyde and 3-epi-11 $\beta$-Dihydroxy BA as precursors in biosynthesis of boswellic acids. PLoS ONE. 13(6):e0198666

Ansari SA, Narayanan C, Wali SA, Kumar R, Shukla N, Rahangdale SK. 2012 ISSR markers for analysis of molecular diversity and genetic structure of Indian teak (Tectona grandis L.f.) populations. Annals of Forest Research 55(1):11-23.

Anuragi H, Dhaduk HL, Kumar S et al. 2016. Molecular diversity of Annona species and proximate fruit composition of selected genotypes. Biotech 3 6:204

Aparajita S, Rout GR. 2010. Molecular analysis of Albizia species using AFLP markers for conservation strategies. Journal of Genetics 89(1):95-99.

Aparajita S, Senapati SK, Rout GR. 2016. A study on Population structure delineated with Inter Simple Sequence Repeat markers in fragmented populations of legume tree Albizia procera. International Journal of Advanced Research 4(2):1126-1132.

Arabidopsis Genome Initiative. 2000. Analysis of the genome sequence of the flowering plant Arabidopsis thaliana. Nature 408:796-815

Argout X, Salse J, Aury J-M et al. 2011. The genome of Theobroma cacao. Nature Genetics 43:101-108, doi:10.1038/ng.736 
Arunachalam A, Chavan SB, Handa AK, Kumar A, Bhaskar S, Alagusundaram K, Mohapatra T. 2019. Agroforestry Systems for the Indian Himalayan Region. Indian Council of Agricultural Research, New Delhi; pp 19.

Asif H, Khan A, lqbal A, Khan IA, Heinze B, Azim MK. 2013. The chloroplast genome sequence of Syzygium cumini (L.) and its relationship with other angiosperms. Tree Genetics and Genomes 9: 867-877 doi: 10.1007/s11295-013-0604-1

Bai W-N, Yan P-C, Zhang B-W et al. 2018. Demographically idiosyncratic responses to climate change and rapid Pleistocene diversification of the walnut genus Juglans (Juglandaceae) revealed by whole-genome sequences. New Phytologist 217:1726-1736. doi: 10.1111/nph.14917

Baison J, Vidalis A, Zhou L et al. 2018. Association mapping identified novel candidate loci affecting wood formation in Norway spruce. BioRxiv [Preprint] doi: 10.1101/292847

Bajpai A, Khan K, Muthukumar M, Rajan S et al. 2018. Molecular analysis of anthocyanin biosynthesis pathway genes and their differential expression in mango peel. Genome 61(3):157-66.

Balasaravanan T, Chezhian P, Kamalakannan R, Ghosh M, Yasodha R, Varghese M, Gurumurthi K. 2005. Determination of inter-and intra-species genetic relationships among six Eucalyptus species based on inter-simple sequence repeats (ISSR). Tree physiology 25(10):1295-1302.

Balasaravanan T, Chezhian P, Kamalakannan R, Yasodha R, Varghese M, Gurumurthi K, Ghosh M. 2006. Identification of species diagnostic ISSR markers for six Eucalyptus species. Silvae Genetica 55(1-6):119-122.

Barghini E, Mascagni F, Giordani T et al 2017. An insight into structure and composition of the fig genome. Acta Horticulture 1173:69-74. doi: 10.17660/ActaHortic.2017.1173.12

Bartholome J, Heerwaaeden JV, Isil F et al. 2016. Performance of genomic prediction within and across generations in maritime pine. BMC Genomics 17:604. doi:10.1186/s12864-0162879-8

Beaulieu J, Doerksen T, Boyle B. 2011. Association genetics of wood physical traits in the conifer white spruce and relationships with gene expression. Genetics 188:197-214. doi: 10.1534/genetics.110

Beaulieu J, Doerksen T, Clement TD et al. 2014a. Accuracy of genomic selection models in a large population of open-pollinated families in white spruce. Heredity 113:343-352. doi:10.1038/hdy.2014.36 
Beaulieu J, Doerksen TK, MacKay J et al. 2014b. Genomic selection accuracies within and between environments and small breeding groups in white spruce. BMC Genomics 15:1048, https://doi.org/10.1186/1471-2164-15-1048

Bernard A, Marrano A, Donkpegan A et al. 2020. Association and linkage mapping to unravel genetic architecture of phenological traits and lateral bearing in Persian walnut (Juglans regia L.). BMC Genomics 21:203. Doi: 10.1186/s12864-020-6616-y

Bhambhani S, Lakhwani L, Gupta P et al. 2017. Transcriptome and metabolite analyses in Azadirachta indica: identification of genes involved in biosynthesis of bioactive triterpenoids. Scientific Reports 7:5043. doi:10.1038/s41598-017-05291-3

Bhandawat A, Singh G, Seth R, Singh P, Sharma R K. 2017. Genome-wide transcriptional profiling to elucidate key candidates involved in bud burst and rattling growth in a subtropical bamboo (Dendrocalamus hamiltonii). Frontiers in plant science 7:2038.

Bhat JA, Ali S, Salgotra RK, Mir ZA, Dutta S, Jadon V, Tyagi A, Mushtaq M, Jain N, Singh PK, Singh GP. 2016. Genomic selection in the era of next generation sequencing for complex traits in plant breeding. Frontiers in genetics 7:221.

Birol I, Raymond A, Jackman SD, Pleasance S, Coope R, Taylor GA, Yuen MM, Keeling Cl, Brand D, Vandervalk BP, Kirk H, Pandoh P, Moore RA, Zhao Y, Mungall AJ, Jaquish B, Yanchuk A, Ritland C, Boyle B, Bousquet J, Ritland K, Mackay J, Bohlmann J, Jones SJ. 2013. Assembling the $20 \mathrm{~Gb}$ white spruce (Picea glauca) genome from whole-genome shotgun sequencing data. Bioinformatics. 2013 Jun 15;29(12):1492-7. doi: 10.1093/bioinformatics/btt178. PMID: 23698863; PMCID: PMC3673215.

Biscarini F, Nazzicari N, Bink M et al. 2017. Genome-enabled predictions for fruit weight and quality from repeated records in European peach progenies. BMC Genomics 18:432 Doi: 10.1186/s12864-017-3781-8

Biswas B, Kazakoff SH, Jiang QY, S Samuel. 2013. Genetic and genomic analysis of the tree legume Pongamia pinnata as a feedstock for biofuels. The Plant Genome 6:1-15

Boff T, Schifino-Wittmann MT. 2003 Segmental allopolyploidy and paleopolyploidy in species of Leucaena benth: evidence from meiotic behavior analysis. Hereditas 138:27-35.

Butler JB, Freeman JS, Potts BM et al. 2018. Annotation of the Corymbia terpene synthase gene family shows broad conservation but dynamic evolution of physical clusters relative to Eucalyptus. Heredity 121(1):87-104

Cappa EC, El-Kassaby YA, Garcia MN. 2013. Impacts of population structure and analytical models in genome-wide association studies of complex traits in forest trees: a case study 
in Eucalyptus globulus. PLoS ONE 8:e81267.

https://doi.org/10.1371/journal.pone.0081267

Carocha V, Marçal S, Hefer C et al. 2015. Genome-wide analysis of the lignin toolbox of Eucalyptus grandis. New Phytologist 206. doi: 10.1111/nph.13313.

Ch. Mohan, Naresh B, Reddy MS, Kumar SM, Cherku PD. 2017. Genetic similarity studies of Commiphora wightii accessions by fluorescent-labeled RAPD primers. International Journal of Biotechnology and Biochemistry 13(1):55-66

Chagne D, Crowhurst RN, Pindo M et al. 2014. The draft genome sequence of European Pear (Pyrus communis L. 'Bartlett'). PLoS ONE https://doi.org/10.1371/journal.pone.0092644

Chand L, Singh DB, Kumawat KL, Rai KM, Sharma OC, Sharma A, Saini P, Handa AK. 2020. Genetic variability, correlation and path-coefficient studies among Persian walnut (Juglans regia) genotypes. Indian Journal of Agricultural Sciences 90(5):28-33.

Chand L, Singh DB, Sharma OC, Mir JI, Kumawat KL, Rai KM, Rather SA, Qureshi I, Lal S, Dev I. 2017. Lateral bearing trait in Indian Walnut (Juglans regia L.) germplasm: a potential yield contributing trait in early age of the tree. International Journal of Bio-resource and Stress Management 8(5):605-610.

Chang Y, Liu H, Liu M et al. 2018. The draft genomes of five agriculturally important African orphan crops. GigaScience 8(3):1-16. https://doi.org/10.1093/gigascience/giy152

Chaturvedi OP, Handa AK, Kaushal R, Uthappa AR, Sarvade S, Panwar P. 2016. Biomass production and carbon sequestration through agroforestry. Range Management and Agroforestry 37(2):116-127.

Chaturvedi OP, Handa AK, Uthappa AR, Sridhar KB, Kumar Naresh, Chavan SB, Rizvi Javed. 2017. Promising agroforestry tree species in India. Jointly published by the Central Agroforestry Research Institute (CAFRI), Jhansi, and the South Asia Regional Programme (based in Delhi, India) of the World Agroforestry Centre.

Chauhan P, Ginwal HS, Barthwal S. 2010. Cross-species transferability of SSR markers in Pinus roxburghii. The International Forestry Review 12(5):318.

Chezhian P, Yasodha R, Ghosh M. 2010. Genetic diversity analysis in a seed orchard of Eucalyptus tereticornis. New Forests 40:85-99.

Choudhury RR, Bak S, Ramesh AM, Rangan L. 2014. Nuclear DNA content of Pongamia pinnata L. and genome size stability of in vitro-regenerated plantlets. Protoplasma 251(3):703-709. 
Christie N, Tobias PA, Naidoo S, Kulheim C. 2015. The Eucalyptus grandis NBS-LRR gene family: physical clustering and expression hotspots. Frontiers in Plant Science 6:1238. 10.3389/fpls.2015.01238

Clarke J, Wu H, Jayasinghe L, Patel A. 2009. Continuous base identification for single molecule nanopore DNA sequencing. National Nanotechnol 4:265-270

Cornejo OE, Yee M-C, Dominguez V et al. 2018. Population genomic analyses of the chocolate tree, Theobroma cacao L., provide insights into its domestication process. Communications Biology 1:167. doi:10.1038/s42003-018-0168-6

Cros D, Denis M, Sanchez M et al. 2015. Genomic selection prediction accuracy in a perennial crop: case study of oil palm (Elaeis guineensis Jacq.). Theoretical and Applied Genetics 128:397-410

Dagher-Kharrat MB, Grenier G, Bariteau M, Brown SC, Siljak-Yakovlev S, Savoure A. 2001. Karyotype analysis reveals interspecific differentiation in the genus Cedrus despite genome size and base composition constancy. Theoretical and Applied Genetics 103: 846-854

Dasgupta MG, Dharanishanthi V, Agarwal I, Krutovsky KV. 2015. Development of genetic markers in Eucalyptus species by target enrichment and exome sequencing. PLOS ONE 10(1):e0116528. doi:10.1371/journal.pone.0116528

Dasgupta MG, Ulagaan K, Dev SA et al. 2019. Draft genome of Santalum album L. provides genomic resources for accelerated trait improvement. Tree Genetics and Genomes 15:34. doi:10.1007/s11295-019-1334-9

Datta RK. 2000. Mulberry cultivation and utilisation in India. Proceedings of the electronic conference on mulberry for animal production (Morus-L). Available online http://www.fao.org/ DOCREP/005/ X9895E/x9895e03.htm.

Davin N, Edger PP, Hefer CA et al. 2016. Functional network analysis of genes differentially expressed during xylogenesis in soc1ful woody Arabidopsis plants. Plant Journal 86:376390. doi: $10.1111 /$ tpj.13157

Dellaporta SL, Wood J, Hicks JB. 1983. A plant DNA mini-preparation: version II. Plant Molecular Biology Reporter 1:19-21.

Deshwal RPS, Singh R, Malik K, Randhawa GJ. 2003. Assessment of genetic diversity and genetic relationships among 29 populations of Azadirachta indica A. Juss. using RAPD markers. Genetic Resources and Crop Evolution 52:285-292. 
Dharanishanthi V, Ghosh Dasgupta M. 2017. Isolation and characterization of homeodomain leucine zipper class-III transcription factor gene in Eucalyptus tereticornis. Indian Journal of Biotechnology 16:334-339.

Dharanishanthi V, Ghosh Dasgupta M. 2018a. Co-expression network of secondary cell wall biogenesis genes in Eucalyptus tereticornis. Silvae Genetica 67:72-78.

Dharanishanthi V, Ghosh Dasgupta M. 2018b. Co-expression network of transcription factors reveal ethylene-responsive element-binding factor as key regulator of wood phenotype in Eucalyptus tereticornis. 3 Biotech 8(7):315

Dharanishanthi V, Ghosh Dasgupta M.2016. Construction of co-expression network based on natural expression variation of xylogenesis-related transcripts in Eucalyptus tereticornis. Molecular Biology Reports 43:1129-1146.

Diallo BO, Doyle M, Doyle MMHC et al. 2008. Breeding system and pollination biology of the semi-domesticated fruit tree, Tamarindus indica L. (Leguminosae: Caesalpinioideae): Implications for fruit production, selective breeding, and conservation of genetic resources. African Journal of Biotechnology 7:4068-4075

Diallo BO, Joly HI, McKey D, Hosaert-McKey M, Chevallier MH. 2007. Genetic diversity of Tamarindus indica populations: Any clues on the origin from its current distribution? African Journal of Biotechnology 6(7):853-860

Dijk EL, Jaszczyszyn Y, Naquin D, Thermes C. 2018. The third revolution in sequencing technology. Trends in Genetics 34(9):666-681.

Dobhal S, Sharma S, Ahmed N, Kumar A.2019. Genetic Polymorphism in Dalbergia sissoo Roxb. Using RAPD markers. Indian Journal of Biotechnology 18:164-173.

Dunker B, Dormontt EE, Dixon RR, Jardine DI, Kireta D, Nurtjahjaningsih ILG et al. 2019. A set of 156 SNP markers for teak (Tectona grandis Linn. f.). Conservation Genetics Resources 12:205-207

Duran R, Isik F, Zapata-Valenzuela J et al. 2017. Genomic predictions of breeding values in a cloned Eucalyptus globulus population in Chile. Tree Genetics and Genomes 13:74. doi: 10.1007/s11295-017-1158-4

Durney BC, Crihfield CL, Holland LA. 2015. Capillary electrophoresis applied to DNA: determining and harnessing sequence and structure to advance bioanalyses (20092014). Analytical and bioanalytical chemistry 407(23): 6923-6938.

Eckardt NA.2000. Sequencing the rice genome. Plant Cell 12:2011-2017. doi:10.1105/tpc.12.11.2011 
Eid J, Fehr A, Gray J, Luong K, Lyle J, Otto G, et al. 2009. Real-time DNA sequencing from single polymerase molecules. Science 323(5910):133-138.

Eisenstein M. 2012. Oxford nanopore announcement sets sequencing sector abuzz. Nature Biotechnology 30:295-296

Evans LM, Slavov GT, Rodgers-Melnick E et al. 2014. Population genomics reveals signatures of selection coupled with adaptive trait associations in the model tree, Populus trichocarpa. Nature Genetics 46:1089-1096. Doi: 10.1038/ng.3075

Fahrenkrog AM, Neves LG, Resende MFR et al. 2017. Genome-wide association study reveals putative regulators of bioenergy traits in Populus deltoides. New Phytology 213:799-811. Doi: 10.1111/nph.14154

FAO (2016). Poplars and other fast-growing trees - Renewable resources for future green Economies. Synthesis of Country Progress Reports. 25th Session of the International Poplar Commission, Berlin, Federal Republic of Germany, 13-16 September. Working Paper IPC/15. Forestry Policy and Resources Division, FAO, Rome. http://www.fao.org/forestry/ipc2016/en/.

Fernandez-Lopez J, Aleta N, Alıas R. 2000. Forest genetic resources conservation of Juglans regia L. IPGRI Publishers, Rome, Italy 20-25.

Fleming PA, Hofmeyr SD, Nicolson SW. 2007. Role of insects in the pollination of Acacia nigrescens (Fabaceae). South African Journal of Botany 73(1):49-55.

Galeano E, Vasconcelos TS, Novais de Oliveira P et al. 2019. Physiological and molecular responses to drought stress in teak (Tectona grandis L.f.). PloS ONE 14(9).

Galeano E, Vasconcelos TS, Vidal M et al. 2015. Large-scale transcriptional profiling of lignified tissues in Tectona grandis. BMC Plant Biology 15: 221

Geetha KA, Kawane A, Bishoyi AK et al. 2013. Characterization of mode of reproduction in Commiphora wightii [(Arnot) Bhandari] reveals novel pollen-pistil interaction and occurrence of obligate sexual female plants. Trees 27:567-581. doi:10.1007/s00468-0120810-8

Geraldes A, Hannemann J, Grassa C et al. 2013. A 34K SNP genotyping array for Populus trichocarpa: design, application to the study of natural populations and transferability to other Populus species. Molecular Ecology Resources 13:306-323. doi: 10.1111/17550998.12056 
Ghosh Dasgupta M, Dharanishanthi V. 2017. Identification of PEG-induced water stress responsive transcripts using co-expression network in Eucalyptus grandis. Gene 627:393407

Ghosh Dasgupta M, Veluthakkal R, Karpaga RSB. 2013. Characterization of genes expressed in Casuarina equisetifolia in response to elicitation by cell wall components of Trichosporium vesiculosum. Silvae Genetica 62:161-173.

Ghosh M, Chezhian P, Sumathi R, Yasodha R. 2011. Development of SCAR marker in Casuarina equisetifolia for species authentication. Trees 25:465-472.

Ginwal HS, Chauhan P, Barthwal S, Sharma S, Sharma R. 2011. Short note: cross-species amplification and characterization of pinus chloroplast microsatellite markers in Cedrus deodara Roxb. Silvae Genetica 60:2.

Ginwal HS, Maurya SS. 2010. Evaluation and optimization of DNA extraction method for Dalbergia sissoo leaf. Indian Journal of Biotechnology 9(1):69-73.

Govindarajulu R, Hughes CE, Alexander PJ, Bailey CD. 2011. The complex evolutionary dynamics of ancient and recent polyploidy in Leucaena (leguminosae; mimosoideae). American Journal of Botany 98(12):2064-2076.

Grattapaglia D, Vaillancourt RE, Shepherd M et al. 2012. Progress in Myrtaceae genetics and genomics: Eucalyptus as the pivotal genus. Tree Genetics and Genomes 8:463-508. doi: 10.1007/s11295-012-0491-x

Groover A, Crook Q (eds). 2017. Comparative and Evolutionary Genomics of Angiosperm Trees. Berlin: Springer Publishing. 366;10.1007/978-3-319-49329-9

Guan R, Zhao Y, Zhang $\mathrm{H}$ et al. 2016. Draft genome of the living fossil Ginkgo biloba. GigaScience 5:49. doi:10.1186/s13742-016-0154-1

Gulyani V, Khurana P. 2011. Identification and expression profiling of drought-regulated genes in mulberry (Morus sp.) by suppression subtractive hybridization of susceptible and tolerant cultivars. Tree Genetics and Genomes 7:725-738

Gunasena HPM, Hughes A 2000. Tamarind. International Centre for Underutilized Crops, Southampton, UK: 170

Guo D-L, Zhao H-L, Zhang G-H et al. 2019. Genome-wide association study of berry related traits in grape (Vitis vinifera L.) based on genotyping-by-sequencing markers. Horticulture Research 6:11. doi:10.1038/s41438-018-0089-z

Gupta VK, Dhyani SK, Ahlawat SP, Kumar RV, Datta A. 2011. Neem germplasm catalogue. National Research Centre for Agroforestry, Jhansi (UP), India. 
Gupta Y, Pathak AK, Singh K, Mantri SS, Singh SP, Tuli R. 2015. De novo assembly and characterization of transcriptomes of early-stage fruit from two genotypes of Annona squamosa L. with contrast in seed number. BMC genomics 16(1):86.

Ha J, Shim S, Lee T, Kang YJ et al. 2019. Genome sequence of Jatropha curcas L., a non-edible biodiesel plant, provides a resource to improve seed-related traits. Plant Biotechnology Journal 17(2):517-530. doi:10.1111/pbi.12995.

Haque I, Bandopadhyay R, Mukhopadhyay K. 2009a. Intraspecific variation in Commiphora wightii populations based on internal transcribed spacer (ITS-5.8S-ITS2) sequence of rDNA. Diversity 1:89-101

Haque I, Bandopadhyay R, Mukhopadhyay K. 2009b. Population genetic structure of the endangered and endemic medicinal plant Commiphora wightii.Molecular biology reports $37(2): 847$.

Harish, Gupta AK, Phulwaria M, Rai MK, Shekhawat NS. 2014. Conservation genetics of endangered medicinal plant Commiphora wightii in Indian Thar Desert. Gene 535:266-272

Hazzouri KM, Gros-Balthazard M, Flowers JM et al. 2019. Genome-wide association mapping of date palm fruit traits. Nature Communication 10:4680. doi:10.1038/s41467-019-126049

He N, Zhang C, Qi X et al. 2013. Draft genome sequence of the mulberry tree Morus notabilis. Nature Communication 4:2445. https://doi.org/10.1038/ncomms3445

Heather JM, Chain B. 2016. The sequence of sequencers: The history of sequencing DNA. Genomics 107(1):1-8.

Hedrick P, Hellesten U, Grattapaglia D. 2016. Examining the cause of high inbreeding depression: analysis of whole-genome sequence data in 28 selfed progeny of Eucalyptus grandis. New Phytology 209:600-611. doi: 10.1111/nph.13639

Hefer CA, Mizrachi E, Myburg AA et al. 2015. Comparative interrogation of the developing xylem transcriptomes of two wood-forming species: Populus trichocarpa and Eucalyptus grandis. New Phytology 206:1391-1405. doi:10.1111/nph.13277

Hendre PS, Muthemba S, Kariba R, Muchugi A, Fu Y, Chang Y et al. 2019. African Orphan Crops Consortium (AOCC): status of developing genomic resources for African orphan crops. Planta 250:989-1003

Henry IM, Zinkgraf MS, Groover AT et al. 2015. A system for dosage-based functional genomics in poplar. Plant Cell 27:2370-2383. 
Hickey JM, Chiurugwi T, Mackay I et al. 2017. Implementing genomic selection in CGIAR breeding programs workshop participants. Genomic prediction unifies animal and plant breeding programs to form platforms for biological discovery. Nature Genetics 49(9):12971303. doi:10.1038/ng.3920

Hiremath SC, Nagasampige MH. 2004. Genetic relationships among some species of Dalbergia using PCR based DNA markers. Cytologia 69(2):125-130.

Hodgson H, Peña RDL, Stephenson MJ et al. 2019. Identification of key enzymes responsible for protolimonoid biosynthesis in plants: Opening the door to azadirachtin production. PNAS 116. 17096-17104

Huang J, Zhang C, Zhao X et al. 2016. The Jujube genome provides insights into genome evolution and the domestication of sweetness/acidity taste in fruit trees. PLoS Genetics https://doi.org/ 10.1371/journal.pgen.1006433

Huang S, Ding J, Deng D et al. 2013. Draft genome of the kiwifruit Actinidia chinensis. Nature Communication 4:2640. https://doi.org/10.1038/ncomms3640

Huo Y. 2000. Mulberry cultivation in China. Paper presented in the FAO Electronic Conference on mulberry for animal production (Morus1-L), 1May- 31 June 2000, FAO Rome.

Hussey SG, Saidi MN, Hefer CA et al. 2015. Structural, evolutionary and functional analysis of the NAC domain protein family in Eucalyptus. New Phytology 206:1337-1350. 10.1111/nph.13139

III DL, Stack C, Mustiga GM et al. 2017. A Larger Chocolate Chip-Development of a 15K Theobroma cacao L. SNP array to create high-density linkage maps. Frontiers in Plant Science 8:2008. https://doi.org/10.3389/fpls.2017.02008

lquebal MA, Sarika Jaiswal, AK Mahato et al. 2017. MiSNPDb: a web-based genomic resources of tropical ecology fruit mango (Mangifera indica L.) for phylo-geography and varietal differentiation. Scientific Reports 7(1):14968. doi:10.1038/s41598-017-14998-2

Ishihara K, Lee EKW, Borthakur D. 2016a. An improved method for RNA extraction from woody legume species Acacia koa A. Gray and Leucaena leucocephala (Lam.) de Wit. International Journal of Forestry Wood Sciences 3:31-35.

Ishihara KL, Honda MDH, Pham DTR, Borthakur D. 2016b. Transcriptome analysis of Leucaena leucocephala and identification of highly expressed genes in roots and shoots. Transcriptomics 4:1 10.4172/2329-8936.1000135 
Jaillon O, Aury J-M, Noel B et al. 2007. The grapevine genome sequence suggests ancestral hexaploidization in major angiosperm phyla. Nature 449:463-467. doi:10.1038/nature06148

Jamnadass R, Mumm RH, Hale I et al. 2020. Enhancing African orphan crops with genomics. Nature Genetics 52:356-360. https://doi.org/10.1038/s41588-020-0601-x

Javaid A, Akram W, Shoaib A et al. 2014. ISSR analysis of genetic diversity in Dalbergia sissoo in Punjab, Pakistan. Pakistan Journal of Botany 46(5):1573-1576.

Jha TB. 2014. Somatic chromosomes of Aegle marmelos and Azadirachta indica through EMA method. Nucleus 57(3):185-188

Jiang Q, Yen SH, Stiller J. 2012. Genetic, biochemical and morphological diversity of the legume biofuel tree Pongamia pinnata. Journal of Plant Genome Science 1:54- 67

Jiao Y, Jia H, Li X, et al. 2012 Development of simple sequence repeat (SSR) markers from a genome survey of Chinese bayberry (Myrica rubra). BMC Genomics 13:201 https://doi.org/10.1186/1471-2164-13-201

Jin Y, Liu L, Hao X et al. 2019. Unravelling the MicroRNA-mediated gene regulation in developing Pongamia seeds by high-throughput small RNA profiling. International Journal of Molecular Sciences 20(14)

Johar V, Kajla S, Dhillon RS et al. 2017. Evaluation of genetic diversity using random amplified polymorphic DNA (RAPD) markers in Melia dubia Cav. Indian Journal of Biotechnology 16:76-83

Joshi G, Chauhan SSA, Ajay AN et al 2019. Phenotyping using pilodyn as a tool, selective genotyping and preliminary genetic diversity estimation for wood basic density in Melia dubia. Academia Journal of Biotechnology 7(6):107-115.

Joshi G, Chauhan SSA, Ajay AN et al. 2018. Wood stiffness as a trait for phenotyping, selective genotyping and preliminary genetic diversity estimation using SSR markers in Melia dubia. Academia Journal of Biotechnology 10(11):541-547.

Joubert W, Nance J, Weighill D, Jacobson D. 2018. Parallel accelerated vector similarity calculations for genomics applications. Parallel Computing 75:130-145.

Joubert W, Nance J, Climer S et al. 2017. Parallel accelerated custom correlation coefficient calculations for genomics applications. arXiv [Preprint]. arXiv:1705.08213

Kabra A, Martins N, Sharma R, Kabra R, Baghel US. 2019. Myrica esculenta Buch.-Ham. ex D. Don: A Natural Source for Health Promotion and Disease Prevention. Plants (Basel) 8(6):149. doi:10.3390/plants8060149 
Kancharla N, Jalali S, Narasimham JV et al. 2019. De Novo Sequencing and Hybrid Assembly of the Biofuel Crop Jatropha curcas L.: Identification of quantitative trait loci for geminivirus resistance. Genes 10:69. doi :10.3390/genes10010069.

Karger BL, Guttman A. 2009. DNA sequencing by CE. Electrophoresis 30(S1): S196-S202.

Kazakoff SH, Imelfort M, Edwards D, Koehorst J, Biswas B, Batley J, Scott PT, Gresshoff PM. 2012. Capturing the biofuel wellhead and powerhouse: the chloroplast and mitochondrial genomes of the leguminous feedstock tree Pongamia pinnata. PLOS ONE 7(12). doi.org/10.1371/journal.pone.0051687

Khan AL, Al-Harrasi A, Asaf S et al. 2017. The first chloroplast genome sequence of Boswellia sacra, a resin-producing plant in Oman. PLoS ONE 12(1):e0169794. Doi:10.1371/journal.pone.0169794

Koboldt DC, Steinberg KM, Larson DE, Wilson RK, Mardis ER. 2013. The next-generation sequencing revolution and its impact on genomics. Cell 155(1):27-38.

Kole PR, Bhat KV, Chaudhury R, Malik SK et al. 2015b. Genetic diversity analysis in wild species of Pongamia pinnata (L.) using RAPD and SRAP markers. Journal of Advances in Biotechnology 4(3):442-452.

Kole PR, Bhat KV, Chaudhury R, S. K. Malik. 2015a. Genetic variation among Jatropha curcas L. using dominant molecular marker collected from different agro-climatic regions of India. Indian Journal of Genetics 75(2):267-270, doi: 10.5958/0975-6906.2015.00043.7

Kreethika A, Chavan SB, Shukla M. 2015. Khejri agroforestry for addressing issue of soil heath. Life Sciences Leaflets. 64:102-108

Krishnan NM, Jain P, Gupta S, Hariharan AK et al. 2016. An improved genome assembly of Azadirachta indica A. Juss. G3: Gene, Genome, Genetics 6:1835-1840

Krishnan NM, Pattnaik S, Jain $P$ et al. 2012. A draft of the genome and four transcriptomes of a medicinal and pesticidal angiosperm Azadirachta indica. BMC Genomics 13:464, doi:10.1186/1471-2164-13-464.

Krishnan RR, Sumathy R, Bindroo BB, Naik VG. 2014. MulSatDB: a first online database for mulberry microsatellites. Trees 28:1793-1799 doi:10.1007/s00468-014-1086-y

Kuhn DN, Livingstone III DS, Richards JH, Manosalva P, Van den Berg N, Chambers AH. 2019. Application of genomic tools to avocado (Persea americana) breeding: SNP discovery for genotyping and germplasm characterization. Scientia horticulturae 246:1-11.

Kulhari A, Singh R, Chaudhury A, Dhawan AK, Kalia RK. 2015. Assessment of genetic variability through ISSR and RAPD markers in Commiphora wightii (Arn.) Bhandari. Acta 
Physiologiae Plantarum 37: article 113, 14 pages

Kulheim C, Padovan A, Hefer C, Krause ST et al. 2015. The Eucalyptus terpene synthase gene family. BMC Genomics 16:450. doi: 10.1186/s12864-015-1598-x

Kumar P, Parthiban KT, Saravanan V. 2013. Genetic variations among open pollinated families of selected better trees in Melia dubia. Research Journal of Recent Sciences 2:189-194

Kumar S, Chagne D, Bink MCAM, Volz RK et al. 2012. Genomic selection for fruit quality traits in apple (Malus domestica Borkh.). PLoS ONE 7: e36674

Kumar V, Malik SK, Pal D, Srinivasan R et al. 2014. Comparative transcriptome analysis of ovules reveals stress related genes associated with nucellar polyembryony in citrus. Tree Genetics \& Genomes 16: doi: 10.1007/s11295-013-0690-0

Kundu SK. 1999. The mating system and genetic significance of polycarpy in the neem tree (Azadirachta indica). Theoretcial and Applied Genetics 99:1216-1220

Kuravadi NA, Yenagi V, Rangiah K et al. 2015. Comprehensive analyses of genomes, transcriptomes and metabolites of Neem tree. PeerJ-the Journal of Life and Environmental Sciences 3:e1066. doi: 10.7717/peerj.1066.

Lal S, AK Singh, SK Singh, M Srivastav et al. 2017. Association analysis for pomological traits in mango (Mangifera indica L.) by genic-SSR markers. Trees 1-19

Lau N, Makita Y, Kawashima M et al. 2016. The rubber tree genome shows expansion of gene family associated with rubber biosynthesis. Scientific Reporter 6:28594. Doi: 10.1038/srep28594

Leggett RM, Clark MD. 2017. A world of opportunities with nanopore sequencing. Journal of Experimental Botany 68:5419-5429. doiDOI:10.1093/jxb/erx289

Leone A, Spada A, Battezzati A, Schiraldi A et al. 2015. Cultivation, Genetic, Ethnopharmacology, Phytochemistry and Pharmacology of Moringa oleifera Leaves: An Overview. International Journal of Molecular Sciences 16(6):12791-12835, doi:10.3390/ijms160612791.

Levy SE, Myers RM.2016. Advancements in next-generation sequencing. Annual Review of Genomics and Human Genetics 17: 95-115. DOldoi: 10.1146/annurev-genom-083115022413

Li Q, Qi J, Qin Xet al. 2020. CitGVD: a comprehensive database of citrus genomic variations. Horticultural Research 7:12. DOldoi: 10.1038/s41438-019-0234-3.

Li Wei, Xun-Ge Zhu, Qun-Jie Zhang, Kui Li et al. 2020. SMRT sequencing generates the chromosome-scale reference genome of tropical fruit mango (Mangifera indica). BioRxiv [preprint], doi: https://doi.org/10.1101/2020.02.22.960880 
Li Y, Dungey HS. 2018. Expected benefit of genomic selection over forward selection in conifer breeding and deployment. PLOS ONE 13:e0208232, Doi: 10.1371/journal.pone.0208232

Lim CY, Mat Junit S, Abdulla MA, Abdul Aziz A. 2013. In-vivo biochemical and gene expression analyses of the antioxidant activities and hypo-cholesterolaemic properties of Tamarindus indica fruit pulp extract. PLoS ONE 8(7): e70058. doi:10.1371/journal.pone.0070058

Lin CP, Huang JP, Wu CS, Hsu CY, Chaw SM. 2010. Comparative chloroplast genomics reveals the evolution of Pinaceae genera and subfamilies. Genome biology and evolution 2:504517.

Liu J, Cai HH, Li HQ, Liu ZY, Zheng C, Shi C, Niu YF. 2019. The chloroplast genome of Moringa oleifera (Moringaceae). Mitochondrial DNA Part B 4(1):646-647.

Liu J, Shi C, Shi C-C, et al. 2020. The chromosome-based rubber tree genome provides new insights into spurge genome evolution and rubber biosynthesis. Molecular Plant 13:336350. https://doi.org/10.1016/j.molp.2019.10.017

Liu J, Ye M, Zhu S et al. 2018. Two stage identification of SNP effects on dynamic poplar. Plant Journal 93:286-296. Doi: 10.1111/tpj.13777

Liu K, Li H, Li W et al. 2017. Comparative transcriptomic analyses of normal and malformed flowers in sugar apple (Annona squamosa L.) to identify the differential expressed genes between normal and malformed flowers. BMC plant biology 17(1):170

Liu L, Ramsay T, Zinkgraf M et al. 2015. A resource for characterizing genome-wide binding and putative target genes of transcription factors expressed during secondary growth and wood formation in Populus. Plant Journal 82:887-898.

Ma T, Wang J, Zhou G et al. 2014. Genomic insights into salt adaptation in a desert poplar. Nature Communication 5:2797. Doi: 10.1038/ncomms3797

Mahar KS, Rana TS, Ranade SA, Meena B. 2011. Genetic variability and population structure in Sapindus emarginatus Vahl from India. Gene 485:32-39

Mahato AK, Sharma N, Singh A, Srivastav M et al. 2016. Leaf transcriptome sequencing for identifying genic-SSR markers and SNP heterozygosity in crossbred mango variety 'Amrapali' (Mangifera indica L.). PLoS ONE 11(10):e0164325

Mahesh HB, Subba P, Advani J et al. 2018. Multi-omics driven assembly and annotation of the sandalwood (Santalum album) genome. Plant Physiology 176:2772-2788.

Makdoh K, Lynser MB, Pala KHM. 2014. Marketing of Indigenous Fruits: A Source of Income among Khasi Women of Meghalaya, North East. Indian Journal of Agricultural Sciences 5:1-9. doi: 10.1080/09766898.2014.11884707. 
Malik SK, Uchoi A, Kumar S, Choudhary R et al. 2012. Molecular characterization of Citrus macroptera Montr. (Satkara): An endangered wild species from northeast India, Plant Biosystems - An International Journal Dealing with all Aspects of Plant Biology: Official. Journal of the Societa Botanica Italiana pp:1-7, doi:10.1080/11263504.2012.751063

Mangwanda R, Myburg AA and Naidoo S. 2015. Transcriptome and hormone profiling reveals Eucalyptus grandis defence responses against Chrysoporthe austroafricana. BMC Genomics 16:319. doi: 10.1186/s12864-015-1529-x

Manokar J, Balasubramani SP, Venkatasubramanian P. 2018 Nuclear ribosomal DNA-ITS region based molecular marker to distinguish Gmelina arborea Roxb. Ex Sm. from its substitutes and adulterants. Journal of Ayurveda and Integrative Medicine 9:290-293.

Marrano A, Sideli GM, Leslie CA, Cheng H, Neale DB. 2019. Deciphering of the Genetic Control of Phenology, Yield, and Pellicle Color in Persian Walnut (Juglans regia L.). Frontiers in Plant Science Doi: 10.3389/fpls.2019.01140

Martinez-Garcia PJ, Crepeau MW, Puiu D et al. 2016. The walnut (Juglans regia) genome sequence reveals diversity in genes coding for the biosynthesis of non-structural polyphenols. Plant Journal 87:507-532. doi: 10.1111/tpj.13207

McClure KA, Gong YH, Song J et al. 2019. Genome-wide association studies in apple reveal loci of large effect controlling apple polyphenols. Horticulture Research 6:107. doi:10.1038/s41438-019-0190-y

McElroy MS, Navarro AJR, Mustiga G et al. 2018. Prediction of cacao (Theobroma cacao) resistance to Moniliophthora spp. diseases via genome-wide association analysis and genomic selection. Frontiers in Plant Scienc, 9:343. https://doi.org/10.3389/fpls.2018.00343

McKown AD, Klápštì J, Guya RD et al. 2014. Genome-wide association implicates numerous genes underlying ecological trait variation in natural populations of Populus trichocarpa. New Phytology 203:535-553. Doi: 10.1111/nph.12815

Meena RK, Bhandari MS, Barthwal S, Ginwal HS. 2019. Genetic diversity and structure of Dendrocalamus hamiltonii natural meta-population: a commercially important bamboo species of North East Himalayas. 3Biotech 9:60

Mewalal R, Rai DK, Kainer D et al. 2017. Plant-derived terpenes: a feedstock for specialty biofuels. Trends in Biotechnology 35(3):227-240. doi: 10.1016/j.tibtech.2016.08.00 
Meyer FE, Shuey LS, Naidoo S et al. 2016. Dual RNA-sequencing of Eucalyptus nitens during Phytophthora cinnamomi challenge reveals pathogen and host factors influencing compatibility. Frontiers in Plant Science 7:191. Doi:10.3389/fpls.2016.00191

Minamikawa MF, Nonaka K, Kaminuma E et al. 2017. Genome-wide association study and genomic prediction in citrus: Potential of genomics-assisted breeding for fruit quality traits. Scientific Reports 7:4721. doi:10.1038/s41598-017-05100-x

Ming R, Hou S, Feng Y et al. 2008. The draft genome of the transgenic tropical fruit tree papaya (Carica papaya Linnaeus). Nature 452:991-996, doi:10.1038/nature06856

Mizrachi E, Maloney VJ, Silberbauer J et al. 2014. Investigating the molecular underpinnings underlying morphology and changes in carbon partitioning during tension wood formation in Eucalyptus. New Phytology 2061:351-1363. Doi:10.1111/nph.13152

Mizrachi E, Verbeke L, Christie $\mathrm{N}$ et al. 2017. Network-based integration of systems genetics data reveals pathways associated with lingo-cellulosic biomass accumulation and processing. Proceedings of the National Academy of Sciences 114:1195-1200

Mohammad N, Dahayat A, Yadav M, Shirin F et al. 2018. Genetic diversity and population structure of Litsea glutinosa (Lour.) in Central India. Physiology and Molecular Biology of Plants 24(4):655-663. https://doi.org/10.1007/s12298-018-0556-X

Mohammad N, Mahesh S, Jain YK, Ansari SA. 2017. Effect of discrete (individual) and mixed (bulk) genomic DNA on genetic diversity estimates and population structure in Teak (Tectona grandis L. f.). Indian Journal of Experimental Biology 55(1):44-48

Mohammad N, Mahesh S, Kumar P, Ansari SA. 2012. Genotyping of Santalum album L. accessions through cross-species transferability of SSR markers of Santalum austrocaledonicum and Santalum insulare. Sandalwood Research Newsletter 27:1-5

Mohammad N, Vaishnaw V, Mishra J, Mahesh S et al. 2016. Genetic fidelity testing in micro propagated plantlets of Albizia procera (Roxb.) using RAPD and ISSR markers. Indian Forester 142(6):558-562

Motamayor JC, Mockaitis K, Schumtz J et al. 2013. The genome sequence of the most widely cultivated cacao type and its use to identify candidate genes regulating pod color. Genome Biology 14:r53. doi:10.1186/gb-2013-14-6-r53

Muchero W, Guo J, DiFazio SP et al. 2015. High-resolution genetic mapping of allelic variants associated with cell wall chemistry in Populus. BMC Genomics 16:24. doi: 10.1186/s12864-015-1215-z 
Muller BSF, de Almida FJE, Lima BM et al. 2019. Independent and joint-GWAS for growth traits in Eucalyptus by assembling genome-wide data for 3373 individuals across four breeding populations. New Phytologist 221:818-833. doi: 10.1111/nph.15449

Muranty H, Troggio M, Sadok IB et al. 2015. Accuracy and responses of genomic selection on key traits in apple breeding. Horticulture Research 2:15060. doi:10.1038/hortres.2015.60

Myburg AA, Grattapaglia D, Tuskan GA et al. 2014. The genome of Eucalyptus grandis. Nature 510: 356-362. doi:10.1038/nature13308

Naik D, Singh D, Vartak V, Paranjpe S, Bhargava S. 2009. Assessment of morphological and genetic diversity in Gmelina arborea Roxb. New Forests 38(1):99-115.

Naithani HB, Nautiyal S. 2012. Indian Poplars with special reference to indigenous species. Forestry Bulletin 12(1): 1-8

Nakano K, Shiroma A, Shimoji M.2017. Advantages of genome sequencing by long-read sequencer using SMRT technology in medical area. Human Cell 30:149-161.DOldoi: $10.1007 / \mathrm{s} 13577-017-0168-8$

Narayanan C, Dubey S, Wali S A et al. 2008. Comparative efficacy of different DNA extraction methods for PCR-based assay in Tectona grandis L.f., Indian Journal of Biotechnology 7:133-136.

Navarro JAR, Phillips-Mora W, Arciniegas-Leal A et al. 2017. Application of genome wide association and genomic prediction for improvement of cacao productivity and resistance to black and frosty pod diseases. Frontiers in Plant Sciences 8:1905. doi:10.3389/fpls.2017.01905

Neale DB, Wegrzyn JL, Stevens KA et al. 2014. Decoding the massive genome of loblolly pine using haploid DNA and novel assembly strategies. Genome Biology 15: R59. doi:10.1186/gb-2014-15-3-r59

Negi VS, Pal A, Singh R, Borthakur D. 2011. Identification of species-specific genes from Leucaena leucocephala using interspecies suppression subtractive hybridization. Annals of Applied Biology 159:387-398

Nicodemus A, Nagarajan B, Narayanan C, Varghese M, Subramanian K. 2005. Genetic variation in Indian teak (Tectona grandis $L f$ ) populations assayed through RAPD markers. Indian Forester 131(9):1121-1131.

Nicodemus A, Sagaria CY, Kannan K, Rangarajan RMA, Singh BG. 2011. Production of interprovenance and inter-specific hybrids of Casuarina equisetifolia and C. junghuhniana and their early evaluation for growth and form traits. In 'Improving smallholder livelihoods 
through improved casuarina productivity. In CL Zhong, K Pinyoupusarerk, A Kalinganire, C Franche (Eds) Proceedings of the 4th International Casuarinas Workshop. (pp. 5-10).

Nock CJ, Baten A and Barkla BJ. 2016. Genome and transcriptome sequencing characterizes the gene space of Macadamia integrifolia (Proteaceae). BMC Genomics 17:937. doi:10.1186/s12864-016-3272-3

Nystedt B, Street NR, Wetterbom A et al. 2013. The Norway spruce genome sequence and conifer genome evolution. Nature 497:579-584. DOldoi:10.1038/nature12211

O'Connor K, Hayes B, Hardner C et al. 2020. Genome-wide association studies for yield component traits in a macadamia breeding population. BMC Genomics 21:19. Doi: 10.1186/s12864-020-6575-3

Oates CN, Kulheim C, Myburg AA et al. 2015. The transcriptome and terpene profile of Eucalyptus grandis reveals mechanisms of defense against the insect pest, Leptocybe invasa. Plant Cell Physiology 56:1418-1428. Doi: 10.1093/pcp/pcv064

Ohri D, Bhargava A, Chatterjee A. 2004. A:Nuclear DNA amounts in 112 species of tropical hardwoods - new estimates. Plant biology 6(5):555-561

Ong SS, Wickneswari R. 2011. Expression profile of small RNAs in Acacia mangium secondary xylem tissue with contrasting lignin content - potential regulatory sequences in monolignol biosynthetic pathway. BMC Genomics 12(3):13

Ong SS, Wickneswari R. 2012. Characterization of microRNAs expressed during secondary wall biosynthesis in Acacia mangium. PLoS ONE 7(11):e49662. doi:10.1371/journal.pone.0049662

Ott A, Schnable JC, Yeh C et al.et al. 2018. Linked read technology for assembling large complex and polyploid genomes. BMC Genomics 19:651. https://doi.org/10.1186/s12864-0185040-z

Pal K, Forcato M, Ferrari F. 2019. Hi-C analysis: from data generation to integration. Biophysical Reviews 11: 67-78. https://doi.org/10.1007/s12551-018-0489-1

Pasha SN, Shafi KM, Joshi AG et al. 2020. The transcriptome enables the identification of candidate genes behind medicinal value of Drumstick tree (Moringa oleifera). Genomics 112(1):621-628

Pauley SS. 1949. Forest-tree genetics research: Populus L. Economic botany 3(3):299-330.

Peters BA, Liu J, Drmanac R. 2014. Co-barcoded sequence reads from long DNA fragments: a cost- effective solution for "perfect genome" sequencing. Front Genet 5:466. 
Pinard D, Mizrachi E, Hefer CA et al. 2015. Comparative analysis of plant carbohydrate active enzymes and their role in xylogenesis. BMC Genomics 16:402. doi: 10.1186/s12864-0151571-8

Pinosio S, Giacomello S, Faivre-Rampant P et al. 2016. Characterization of the poplar pangenome by genomewide identification of structural variation. Molecular Biology and Evolution 33:2706-2719. Doi: 10.1093/molbev/msw161

Plett JM, Kohler A, Khachane A et al. 2015. The effect of elevated carbon dioxide on the interaction between Eucalyptus grandis and diverse isolates of Pisolithus sp. is associated with a complex shift in the root transcriptome. New Phytology 206:1423-1436. Doi: 10.1111/nph.13103

Plomion C, Aury J-M, Amselem J et al. 2016. Decoding the oak genome: public release of sequence data, assembly, annotation and publication strategies. Molecular Ecology Resources 16:574-587. doi: 10.1111/1755-0998

Plomion C, Aury J-M, Amselemet $\mathrm{J}$ et al. 2018. Oak genome reveals facets of long lifespan. Nature Plants, 4: 440-452. doi:10.1038/s41477-018-0172-3

Pootakham W, Sonthirod C, Naktang C et al. 2017. De novo hybrid assembly of the rubber tree genome reveals evidence of paleotetraploidy in Hevea species. Scientific Reporter 7:41457. https://doi.org/10.1038/srep41457

Porth I, Klapste J, Skyba O et al. 2013. Genome-wide association mapping for wood characteristics in Populus identifies an array of candidate single nucleotide polymorphisms. New Phytologist 200:710-726. doi: 10.1111/nph.12422

Poudel RC, Möller M, Liu J, Gao LM, Baral SR, Li DZ. 2014. Low genetic diversity and high inbreeding of the endangered yews in Central Himalaya: implications for conservation of their highly fragmented populations. Diversity and Distributions 20(11):1270-1284

Rahman AYA, Usharraj AO, Misra BB et al. 2013. Draft genome sequence of the rubber tree Hevea brasiliensis. BMC Genomics 14:75. https://doi.org/10.1186/1471-2164-14-75

Rai KC, Chauhan P, Rawat A, Saha R, Ginwal HS 2020. Assessment of Genetic Diversity of Cedrus deodara Roxb. through Random Amplified Polymorphic DNA. Indian Forester 146(1):32-35.

Rai KC, Ginwal HS, Saha R. 2018. Genetic Diversity and Population Structure of Pinus kesiya through Trans-specific Amplification of Nuclear SSR Markers. International Journal of Agriculture, Environment and Biotechnology 1(5):733-739 
Rai KC, Ginwal HS. 2018. Microsatellite analysis to study genetic diversity in Khasi Pine (Pinus kesiya Royle ex. Gordon) using chloroplast SSR markers. Silvae Genetica 67:99-105

Rai MK, Shekhawat JK, Kataria V, Shekhawat NS. 2017. De novo assembly of leaf transcriptome, functional annotation and genomic resources development in Prosopis cineraria, a multipurpose tree of Indian Thar Desert. Plant Gene 12:88-97

Rajarajan K, Vimla Devi S, Handa AK et al. 2015. A simple and effective method for high quality PCR usable DNA extraction from Azadirachta indica A.juss. Indian Journal of Agroforestry 17(1):24-28

Rani A, Ravikumar P, Reddy MD, Kush A. 2013. Molecular regulation of santalol biosynthesis in Santalum album L. Gene 527(2):642-648. doi: 10.1016/j.gene.2013.06.080

Rao SS, Huntley MH, Durand NC et al. 2014. A 3D map of the human genome at kilobase resolution reveals principles of chromatin looping. Cell 159:1665-1680. doi: 10.1016/j.cell.2014.11.021

Rawat A, Barthwal S, Ginwal HS, Tripathi SB. 2015. Association mapping for identification of ISSR and AFLP markers linked with resin yield in Himalayan Chir Pine (Pinus roxburghii Sarg.). Silvae Genetica 64(5-6):220-239.

Rawat A, Barthwal S, Ginwal HS. 2014. Comparative assessment of SSR, ISSR and AFLP markers for characterization of selected genotypes of Himalayan Chir pine (Pinus roxburghii Sarg.) based on resin yield. Silvae Genetica 63(1-6):94-108.

Rawat S, Arunkumar AN, Annapurna D et al 2018. Genetic diversity of Melia dubia using ISSR markers for natural populations and plantations. International Journal of Genetics, 10(9):490-494

Rendón-Anaya M, Ibarra-Laclette E, Méndez-Bravo A. 2019. The avocado genome informs deep angiosperm phylogeny, highlights introgressive hybridization, and reveals pathogeninfluenced gene space adaptation. Proceedings of National Academy of Sciences USA 116:17081-17089. https://doi.org/10.1073/pnas.1822129116

Resende MDV, Resende Jr MFR, Sansaloni CP et al. 2012. Genomic selection for growth and wood quality in Eucalyptus: capturing the missing heritability and accelerating breeding for complex traits in forest trees. New Phytologist 194:116-128. https://doi.org/10.1111/j.1469-8137.2011.04038.x

Resende RT, Resende MDV, Silva FF et al. 20167. Regional heritability mapping and genomewide association identify loci for complex growth, wood and disease resistance traits in Eucalyptus. New Phytologist 213:1287-1300. doi: 10.1111/nph.14266 
Reuter JA, Spacek DV, Snyder MP. 2015. High-throughput sequencing technologies. Molecular cell 58(4):586-597

Ru WM, Zhang J-T, Zhang F, Zhang GP 2006. Eco-environmental characteristics and endangered causes of Taxus mairei, an endemic to China. Bulletin of Botanical Research 26(5):624-628

Saeed B, Baranwal VK, Khurana P. 2016. Comparative transcriptomics and comprehensive marker resource development in mulberry. BMC Genomics 17:98. doi:10.1186/s12864016-2417-8

Saha R. 2018. Genetic diversity in Quercus leucotrichophora populations through RAPD markers. International Journal of Agriculture, Environment and Biotechnology 11(1):97-101.

Sahu SK, Liu M, Yssel A et al. 2020. Draft genomes of two Artocarpus plants, jackfruit (A. heterophyllus) and breadfruit (A. altilis). Genes 11:27. https://doi.org/10.3390/genes11010027

Saina JK, Li ZZ, Gichira AW, Liao YY. 2018. The complete chloroplast genome sequence of tree of heaven (Ailanthus altissima (mill.)(sapindales: Simaroubaceae), an important pantropical tree. International journal of molecular sciences 19(4):929.

Saini P, Chauhan SS, Shabnam AA, Chand L, Negi, N. 2018. Genetic variability and trait association analysis for agro-morphological markers in mulberry genetic resources from Kashmir, India. International journal of current microbiology and applied sciences 7(4):1799-1812. Doi: 10.20546/ijcmas.2018.704.204

Saini RK.2015. Studies on enhancement of carotenoids folic acid iron and their bioavailability in Moringa oleifera and in vitro propagation. University of Mysore, Mysore

Sairkar PK, Sharma A, Shukla NP. 2016. SCAR marker for identification and discrimination of Commiphora wightii and C. myrrha. Molecular Biology International 2016:1482796, 10pp http://dx.doi.org/10.1155/2016/1482796

Salojärvi J, Smolander OP, Nieminen K et al. 2017. Genome sequencing and population genomic analyses provide insights into the adaptive landscape of silver birch. Nature Genetics 49:904-912, doi:10.1038/ng.3862

Samantaray S, Bishoyi A, Geetha KA, Satyabrata M. 2011. Assessment of genetic diversity using RAPD and ISSR markers in guggul (Commiphora wightii). http://epubs.icar.org.in/ejournal/index.php/JMAP/article/download/4390/1725. 
Samantaray S, Geetha KA, Hidayath KP, Maiti S. 2010. Identification of RAPD markers linked to sex determination in guggal [Commiphora wightii (Arnott.)] Bhandari. Plant Biotechnology Reports 4(1):95-99

Sarkar T, Mogili T, Sivaprasad V. 2017. Improvement of abiotic stress adaptive traits in mulberry (Morus spp.): an update on biotechnological interventions. 3 Biotech 7:214. doi: 10.1007/s13205-017-0829-z

Sasaki T. 2005. The map-based sequence of the rice genome. Nature 436:793-800. https://doi.org/10.1038/nature03895

Shakya S, Siddiqui A, Srivatawa N et al. 2010. Molecular characterization of jamun (Syzygium cumini L. Skeels) genetic resources. International Journal of Fruit Science 10(1):29-3

Shankar MSR, Sugumaran G, Kalaiyarasu T, Niket, B. 2009. A rapid method for isolation of highquality DNA from leaves of Gmelina arborea (Roxb) for molecular analysis. International Journal of Biotechnology Applications 1(2):16-19

Sharma D, Shrestha TM, Lamichhane J. 2020. DNA Barcoding of Myrica esculanta (Kafal), An Indigenous, Multipurpose and Medicinal Plant Species from Nepal, by rbcL and matK Gene. Acta Scientific Pharmaceutical Sciences 4(4):11-18

Sharma SK, Kumar S, Rawat D, Kumaria S et al. 2011. Genetic diversity and gene flow estimation in Prosopis cineraria (L.) Druce: A key stone tree species of Indian Thar desert. Biochemical Systematics and Ecology 39:9-13

Shendure J, Balasubramanian S, Church GM, Gilbert W, Rogers J, Schloss JA, Waterston RH. 2017. DNA sequencing at 40: past, present and future. Nature 550(7676): 345-353

Shirasawa K, Isuzugawa K, Ikenaga M. 2017. The genome sequence of sweet cherry (Prunus avium) for use in genomics-assisted breeding. DNA Research 24:499-508. doi: 10.1093/dnares/dsx020

Silva-Junior OB, Faria DA, Grattapaglia D. 2015. A flexible multi-species genome-wide 60K SNP chip developed from pooled resequencing of 240 Eucalyptus tree genomes across 12 species. New Phytologist 206:1527-1540. doi: 10.1111/nph.13322

Silva-Junior OB, Grattapaglia D. 2015. Genome-wide patterns of recombination, linkage disequilibrium and nucleotide diversity from pooled resequencing and single nucleotide polymorphism genotyping unlock the evolutionary history of Eucalyptus grandis. New Phytology 208:830-845. Doi: 10.1111/nph.13505

Singh NK, Mahato AK, Jayaswal PK, Singh A et al. 2016. Origin, diversity and genome sequence of mango (Mangifera indica L.). Indian Journal of History of Science 51(2):355-368 
Singh NK, Mahato AK, Jayaswal PK, Singh S et al. 2018. A reference genome of mango (Mangifera indica L. cv Amrapali). Plant and Animal Genome XXVI International Conference, January 13-17, 2018, San Diego, CA.. https://pag.confex.com/pag/xxvi/meetingapp.cgi/Paper/30811

Singh R, Ong-Abdullah M, Low E-T L et al. 2013. Oil palm genome sequence reveals divergence of interfertile species in Old and New Worlds. Nature 500:335-339. doi:10.1038/nature12309

Sivakrishnan S, Swamivelmanickam M. 2019. A comprehensive review of Albizia procera (Roxb.) Benth.-an update. International Journal of Pharmacologial Science and Research 10(9):4129-44. doi: 10.13040/IJPSR.0975-8232.10(9).4129-44

Sivalingam PN, Samadia DK, Singh D and Chauhan S. (2016.) Molecular markers to distinguish 'Thar Shoba', a variety of khejri [Prosopis cineraria (L.) Druce], from trees in natural populations. The Journal of Horticultural Science and Biotechnology. 91(4):353-61

Slavov GT, DiFazio SP, Martin J et al. 2012. Genome resequencing reveals multiscale geographic structure and extensive linkage disequilibrium in the forest tree Populus trichocarpa. New Phytology 196:713-725. Doi: 10.1111/j.1469-8137.2012.04258.x

Soler M, Camargo EL, Carocha V et al. 2015. The Eucalyptus grandis R2R3-MYB transcription factor family: evidence for woody growth-related evolution and function. New Phytology 206:1364-1377. Doi: 10.1111/nph.13039

Song Y, Zhang Y, Xu J, Li W et al 2019. Characterization of the complete chloroplast genome sequence of Dalbergia species and its phylogenetic implications. Scientific Reports 9:20401. https://doi.org/10.1038/s41598-019-56727

Spokevicius AV, Tibbits J, Rigault P et al. 2017. Medium term water deficit elicits distinct transcriptome responses in Eucalyptus species of contrasting environmental origin. BMC Genomics 18:284. doi: 10.1186/s12864-017-3664-z

Sreeharsha RV, Mudalkar S, Singha KT, Reddy AR. 2016. Unravelling molecular mechanisms from floral initiation to lipid biosynthesis in a promising biofuel tree species, Pongamia pinnata using transcriptome analysis. Scientific reports 6:34315.

Stanton BJ, Serapiglia MJ, Smart LB. 2014. The domestication and conservation of Populus and Salix genetic resources. Poplars and willows: trees for society and the environment. Wallingford, UK: CAB International, 124-199

Steane DA, Nicolle D, Sansaloni CP, Petroli CD et al. 2011. Population genetic analysis and phylogeny reconstruction in Eucalyptus (Myrtaceae) using high-throughput, genome-wide 
genotyping. Molecular Phylogenetics and Evolution 59(1):206-224. doi:10.1016/j.ympev.2011.02.003

Stefanello MÉA, Pascoal AC, Salvador MJ. 2011. Essential oils from neotropical Myrtaceae: chemical diversity and biological properties. Chemistry \& biodiversity 8(1):73-94

Sumathi M, Ramasamy Y. 2017. Microsatellite allele length variations in inter-specific hybrids of Eucalyptus. Acta Botanica Croatica 76(1):103-106. doi: 10.1515/botcro-2016-0050

Sundari BKR, Dasgupta MG. 2014. Isolation of developing secondary xylem specific cellulose synthase genes and their expression profiles during hormone signalling in Eucalyptus tereticornis. Journal of Genetics 93:403-414.

Suontama M, Klapste J, Telfer E et al. 2019. Efficiency of genomic prediction across two Eucalyptus nitens seed orchards with different selection histories. Heredity 122:370-379. doi:10.1038/s41437-018-0119-5

Suthar S, Thul S, Kukreja AK and Ramawat KG. 2008. RAPD markers reveal polymorphism in Commiphora wightii, an endangered medicinal tree. Journal of Cell Tissue Research 8:1477-1480

Tan B, Grattapaglia D, Martins GS et al. 2017. Evaluating the accuracy of genomic prediction of growth and wood traits in two Eucalyptus species and their F1 hybrids. BMC Genomics 17:110. Doi: 10.1186/s12870-017-1059-6

Tan B, Grattapaglia D, Wu HX et al. 2018. Genomic relationships reveal significant dominance effects for growth in hybrid Eucalyptus. Plant Science 267:84-93. Doi: 10.1016/j.plantsci.2017.11.011

Tan Q, Liu X, Gao H, Xiao W et al. 2019. Comparison between flat and round peaches, genomic evidences of heterozygosity events. Frontiers in Plant Science 10:592. https://doi.org/10.3389/fpls.2019.00592

Thumilan BM, Kadam NN, Biradar J, Sowmya HR et al. 2013. Development and characterization of microsatellite markers for Morus spp. and assessment of their transferability to other closely related species. BMC Plant Biololgy 13:194. doi:10.1186/ 1471-2229-13-194

Thumilan BM, Sajeevan RS, Biradar J, Madhuri T et al. 2016. Development and characterization of genic SSR Markers from Indian mulberry transcriptome and their transferability to related species of Moraceae. PLoS ONE 11(9):e0162909. doi:10.1371/journal.pone.0162909

Tian W, Paudel D, Vendrame W,Wang J. 2017. Enriching genomic resources and marker development from transcript sequences of Jatropha curcas for microgravity studies. 
International Journal of Genomics Article ID 8614160, 14 pages. https://doi.org/10.1155/2017/8614160

Tian Y, Zeng Y, Zhang J, Yang C, Yan L, Wang X et al. 2015. High quality reference genome of drumstick tree (Moringa oleifera Lam.), a potential perennial crop. Science China Life Sciences 58(7):627-638

Tuskan GA, DiFazio S, Jansson S et al. 2006. The genome of black cottonwood, Populus trichocarpa (Torr. \& Gray). Science 313: 5793. doiDOI:10.1126/science.1128691

Uchoi A, Malik SK, Choudhary R, Kumar S et al. 2017. Molecular markers in assessing genetic variation in Indian citron (Citrus medica L.) cultivars collected from different parts of India. Indian Journal of Biotechnology 16:346-356

Urrestarazu J, Muranty H, Denance C et al. 2015. Genome-wide association mapping of flowering and ripening periods in apple. Frontiers in Plant Science 10:1923. doi: 10.3389/fpls.2017.01923

Vaishnav V, Ansari SA. 2018. Genetic differentiation and adaptability of Teak (Tectona grandis L.f.) meta-population in India. Plant Molecular Biology Reporter 36:564-575. https://doi.org/10.1007/s11105-018-1101-3

Vaishnav V, Mohammad N, Wali SA, Kumar R, Tripathi SB, Negi MS, Ansari SA. 2015. AFLP markers for analysis of genetic diversity and structure of teak (Tectona grandis) in India. Canadian Journal of Forestry Research 45:297-306

VanBuren R, Bryant D, Bushakra J M et al. 2016. The genome of black raspberry (Rubus occidentalis). The Plant Journal 87(6):535-547

VanBuren R, Wai CM, Colle M, Wang J, Sullivan S, Bushakra JM, Liachko I, Vining KJ, Dossett M, Finn CE, Jibran R, Chagné D, Childs K, Edger PP, Mockler TC, Bassil NV. 2018. A near complete, chromosome-scale assembly of the black raspberry (Rubus occidentalis) genome. Gigascience 7(8):giy094. DOI: 10.1093/gigascience/giy094. PMID: 30107523; PMCID: PMC6131213.

Velasco R, Zharkikh A, Affourtit J et al 2010. The genome of the domesticated apple (Malus domestica Borkh). Nature Genetics 42:833-839. doi:10.1038/ng.654

Veluthakkal R, Ghosh Dasgupta M. 2012. Isolation and characterization of pathogen defencerelated class I chitinase from the actinorhizal tree Casuarina equisetifolia. Forest Pathology 42:467-480 
Veluthakkal R, Ghosh Dasgupta M. 2015. Agrobacterium-mediated transformation of chitinase gene from the actinorhizal tree Casuarina equisetifolia in Nicotiana tabacum. Biologia $70: 905-914$

Verde I, Abbott AG, Scalabrin S et al 2013. The high-quality draft genome of peach (Prunus persica) identifies unique patterns of genetic diversity, domestication and genome evolution. Nature Genetics 45:487-494, doi:10.1038/ng.2586

Vikashini B, Shanthi A, Ghosh Dasgupta M. 2018. Identification and expression profiling of genes governing lignin biosynthesis in Casuarina equisetifolia L. Gene 676:37-46

Vining KJ, Pomraning KR, Wilhelm LJ, Priest HD, Pellegrini M, Mockler TC et al. 2012. Dynamic DNA cytosine methylation in the Populus trichocarpa genome: tissue-level variation and relationship to gene expression. BMC Genomics 13:27. doi: 10.1186/1471-2164-13-27

Vining KJ, Romanel E, Jones RC et al. 2015. The floral transcriptome of Eucalyptus grandis. New Phytology 206:406-1422. 10.1111/nph.13077

Waikhom SD, Ghosh S, Talukdar NC, Mandi SS. 2012. Assessment of genetic diversity of landraces of Dendrocalamus hamiltonii using AFLP markers and association with biochemical traits. Genetics and Molecular Research 11(3):2107-2121

Wang H, Gong M, Guo J. 2018. Genome-wide identification of Jatropha curcas MAPK, MAPKK, and MAPKKK gene families and their expression profile under cold stress. Scientific Reports 8:16163. doi:10.1038/s41598-018-34614-1

Wang J, Chen D, Lei $Y$ et al. 2014. Citrus sinensis annotation project (CAP): a comprehensive database for sweet orange genome. PLoS ONE 9(1):e87723. Doi: 10.1371/journal.pone.0087723

Wang L, He F, Huang Y, He J, Yang S, Zeng J, Xu R. 2018. Genome of wild mandarin and domestication history of mandarin. Molecular plant 11(8):1024-1037

Wang O, Chin R, Cheng X, Wu MKY, Mao Q, Tang J, et al. 2019. Efficient and unique cobarcoding of second-generation sequencing reads from long DNA molecules enabling cost-effective and accurate sequencing, haplotyping, and de novo assembly. Genome research 29(5):798-808

Wang $\mathrm{P}$, Luo $\mathrm{Y}$, Huang $\mathrm{J}$ et al. 2020. The genome evolution and domestication of tropical fruit mango. Genome Biology 21: 60. https://doi.org/10.1186/s13059-020-01959-8

Wang T, Chen Y, Zhuang W et al. 2019. Transcriptome Sequencing Reveals Regulatory Mechanisms of Taxol Synthesis in Taxus wallichiana var. Mairei. International Journal of Genomics 2019:e1596895. Doi:10.1155/2019/1596895 
Wang X, Xu Y, Zhang S, Cao L, Huang Y, Cheng J, et al. 2017. Genomic analyses of primitive, wild and cultivated citrus provide insights into asexual reproduction. Nature genetics 49(5):765.

Wang $\mathrm{Y}$, Chen $\mathrm{X}$, Wang $\mathrm{J}$ et al. 2016. Comparative analysis of the terpenoid biosynthesis pathway in Azadirachta indica and Melia azedarach by RNA-seq. SpringerPlus 5:819. doi:10.1186/s40064-016-2460-6

Weeks A, Simpson BB. 2007. Molecular phylogenetic analysis of Commiphora (Burseraceae) yields insight on the evolution and historical biogeography of an "impossible" genus. Molecular phylogenetics and evolution 42(1):62-79

Weeks, A., Daly, D. C., \& Simpson, B. B. (2005). The phylogenetic history and biogeography of the frankincense and myrrh family (Burseraceae) based on nuclear and chloroplast sequence data. Molecular phylogenetics and evolution, 35(1):, 85-101

Wegrzyn JL, Eckert AJ, Choi M. 2010. Association genetics of traits controlling lignin and cellulose biosynthesis in black cottonwood (Populus trichocarpa, Salicaceae) secondary xylem. New Phytologist 188:515-532. doi: 10.1111/j.1469-8137.2010.03415.x

Weighill D, Jones $\mathrm{P}$, Shah $\mathrm{M}$ et al. 2018. Pleiotropic and epistatic network-based discovery: integrated networks for target gene discovery. Frontiers in Energy Research 6:30. Doi: 10.3389/fenrg.2018.00030

Williams AV, Boykin LM, Howell KA, Nevill PG et al. 2015. The complete sequence of the Acacia ligulata chloroplast genome reveals a highly divergent clpP1 gene. PLOS ONE 10(5):e0125768. doi:10.1371/journal.pone.0125768

Wong MML, Cannon CH, Wickneswari R. 2011. Identification of lignin genes and regulatory sequences involved in secondary cell wall formation in Acacia auriculiformis and Acacia mangium via de novo transcriptome sequencing. BMC Genomics 12:342

Wong MML, Cannon CH, Wickneswari R. 2012. Development of high-throughput SNP-based genotyping in Acacia auriculiformis $\times$ Acacia mangium hybrids using short-read transcriptome data. BMC Genomics 13:726

Wu GA, Prochnik S, Jenkins J, Salse J, Hellsten U, Murat F et al. 2014. Sequencing of diverse mandarin, pummelo and orange genomes reveals complex history of admixture during citrus domestication. Nature biotechnology 32(7):656-662.

Wu GA, Terol J, Ibanez V, López-García A, Pérez-Román E, Borredá C et al. 2018. Genomics of the origin and evolution of Citrus. Nature 554(7692):311-316. 
Wu GA, Wang Prochnik S, Jenkins J et al. 2014. Sequencing of diverse mandarin, pummelo and orange genomes reveals complex history of admixture during citrus domestication. Nature Biotechnology 32:656-662. doi:10.1038/nbt.2906

Wu H, Ma T, Kang M, et al. 2019. A high-quality Actinidia chinensis (kiwifruit) genome. Horticulture Research 6:117. https://doi.org/10.1038/s41438-019-0202-y

Wu J, Wang Z, Shi Z et al. 2012. The genome of the pear (Pyrus bretschneideri Rehd.). Genome Research 23:396-408. doi:10.1101/gr.1443 11.112

Xiao Y, Xu P, Fan H, Baudouin L et al. 2017. The genome draft of coconut (Cocos nucifera). GigaScience 6:1-11. doi:10.1093/gigascience/gix095

Xing Y, Liu Y, Zhang Q, Nie X et al. 2019. Hybrid de novo genome assembly of Chinese chestnut (Castanea mollissima). GigaScience 8:giz112. https://doi.org/10.1093/gigascience/giz112

Xu Q, Chen LL, Ruan X, Chen D, Zhu A, Chen C et al. 2013. The draft genome of sweet orange (Citrus sinensis). Nature genetics 45(1):59.

Yadav A, Jayaswal PK, Venkat Raman K et al. 2019. Transcriptome analysis of flowering genes in mango (Mangifera indica L.) in relation to floral malformation. Journal of Plant Biochemistry and Biotechnology 29:193-212. Doi: 10.1007/s13562-019-00541-z

Yang D, Qiu Q, Xu L, Xu Y et al. 2020. The complete chloroplast genome sequence of Santalum album. Mitochondrial DNA Part B 5(1):406-407. doi: 10.1080/23802359.2019.1704199.

Yasodha R, Kathirvel M, Sumathi R, Gurumurthi K, Archak S, Nagaraju J. 2004. Genetic analyses of casuarinas using ISSR and FISSR markers. Genetica 122(2):161-172.

Yasodha R, Vasudeva R, Balakrishnan S, Sakthi AR et al. 2018. Draft genome of a high value tropical timber tree, Teak (Tectona grandis L. f): insights into SSR diversity, phylogeny and conservation. DNA Research 25:409-419, doi: 10.1093/dnares/dsy013

Ye G, Zhang H, Chen B, Nie S et al. 2019. De novo genome assembly of the stress tolerant forest species Casuarina equisetifolia provides insight into secondary growth. The Plant Journal 97:779-794. doi:10.1111/tpj.14159

Yongkang H. 2000. Mulberry cultivation in China. FAO Electronic conference on mulberry for animal production (Morus-L). Available online http://www.fao.org/ DOCREP/005/ X9895E/X9895e03.htm

Zhang J, Yang Y, Zheng K, Xie M et al. 2018. Genome-wide association studies and expressionbased quantitative trait loci analyses reveal roles of HCT2 in caffeoylquinic acid biosynthesis and its regulation by defense-responsive transcription factors in Populus. New Phytologist 220(2):502-516. doi: 10.1111/nph.15297. Epub 2018 Jul 11 
Zhang Q, Chen W, Sun L et al. 2012. The genome of Prunus mume. Nature Communications 3:1318. doi:10.1038/ncomms2290

Zhang Y, Zheng L, Zheng $\mathrm{Y}$ et al. 2019. Assembly and annotation of a draft genome of the medicinal plant Polygonum cuspidatum. Frontier of Plant Science 10:1274. doi: 10.3389/fpls.2019.01274

Zhao D, Hamilton JP, Bhat WW et al. 2019. A chromosomal-scale genome assembly of Tectona grandis reveals the importance of tandem gene duplication and enables discovery of genes in natural product biosynthetic pathways. Gigascience 8(3):giz005

Zhu Q, Xu Y, Yang Y et al. 2019a. The persimmon (Diospyros oleifera Cheng) genome provides new insights into the inheritance of astringency and ancestral evolution. Horticulture Research 6:138. https://doi.org/10.1038/s41438-019-0227-2

Zhu T, Wang L, You FM et al. 2019b. Sequencing a Juglans regia $\times J$. microcarpa hybrid yields high-quality genome assemblies of parental species. Horticulture Research 6:55. https://doi.org/10.1038/s41438-019-0139-1

Zimin A, Stevens KA, Crepeauet MW et al. 2014. Sequencing and assembly of the 22-Gb Loblolly pine genome. Genetics 196: 875-890. doi:10.1534/genetics.113.159715 


\section{WORKING PAPER SERIES}

\section{7}

252. Preferensi Petani terhadap Topik Penyuluhan dan Penyebaran Informasi Agroforestri di Indonesia http://dx.doi.org/10.5716/WP16181.PDF

253. Seri Agroforestri dan Kehutanan di Sulawesi: Keanekaragaman hayati jenis pohon pada hutan rakyat agroforestri di DAS Balangtieng, Sulawesi Selatan http://dx.doi.org/10.5716/WP16182.PDF

254. Potensi dan Tantangan dalam Pengembangan Skema Ko-Investasi Jasa Lingkungan di Kabupaten Buol, Indonesia. http://dx.doi.org/10.5716/WP17008.PDF

255. Keragaman Jenis Pohon dan Pemanfaatannya oleh Masyarakat di Kabupaten Buol, Indonesia. http://dx.doi.org/10.5716/WP17009.PDF

256. Kerentanan dan preferensi sistem pertanian petani di Kabupaten Buol, Indonesia http://dx.doi.org/10.5716/WP17010.PDF

257. Dinamika Perubahan Penggunaan/Tutupan Lahan Serta Cadangan Karbon di Kabupaten Buol, Indonesia. http://dx.doi.org/10.5716/WP17011.PDF

258. The effectiveness of the volunteer farmer trainer approach vis-à-vis other information sources in dissemination of livestock feed technologies in Uganda.

http://dx.doi.org/10.5716/WP17104.PDF

259. Agroforestry and forestry in Sulawesi series: Impact of agricultural-extension booklets on community livelihoods in South and Southeast Sulawesi.

http://dx.doi.org/10.5716/WP17125.PDF

260. Petani Menjadi Penyuluh, Mungkinkah? Sebuah Pendekatan Penyuluhan dari Petani ke Petani di Kabupaten Sumb Timur. http://dx.doi.org/10.5716/WP17145.PDF 
261. Dampak Perubahan Tutupan Lahan terhadap Kondisi Hidrologi di Das Buol, Kabupaten Buol, Sulawesi Tengah: Simulasi dengan Model Genriver http://dx.doi.org/10.5716/WP17146.PDF

262. Analisis Tapak Mata Air Umbulan, Pasuruan, Jawa Timur. Kajian elemen biofisik dan persepsi masyarakat. http://dx.doi.org/10.5716/WP17147.PDF

263. Planned comparisons demystified. http://dx.doi.org/10.5716/WP17354.PDF

264. Soil health decision support for NERC digital soil platforms: A survey report http://dx.doi.org/10.5716/WP17355.PDF

265. Seri Pembangunan Ekonomi Pedesaan Indonesia: Menanam di bukit gundul: Pengetahuan masyarakat lokal dalam upaya restorasi lahan di Sumba

Timur. http://dx.doi.org/10.5716/WP17356.PDF

266. Tree diversity and carbon stock in three districts of Kutai Timur, Pasir and Berau, East Kalimantan http://dx.doi.org/10.5716/WP17357.PDF

267. Tree Diversity and Carbon Stock in Various Land Use Systems of Banyuasin and Musi Banyuasin Districts, South Sumatera http://dx.doi.org/10.5716/WP17358.PDF

268. Tree diversity and carbon stock in various land cover systems of Jayapura, Jayawijaya and Merauke Districts, Papua Province http://dx.doi.org/10.5716/WP17359.PDF

269. Modelling tree production based on farmers' knowledge: case for kapok (Ceiba pentandra) and candlenut (Aleurites mollucana) under various agroforestry scenarios. http://dx.doi.org/10.5716/WP17361.PDF

270. The Impact of Land Cover and Climate Change on Present and Future Watershed Condition. Study case: Tugasan, Alanib and Kulasihan Sub-watershed of Manupali Watershed, Lantapan, Bukidnon, Philippines. http://dx.doi.org/10.5716/WP17362.PDF 
271. Tree Diversity and Above-ground Carbon Stock estimation in Various Land use Systems in Banjarnegara, Banyumas and Purbalingga, Central Java.

http://dx.doi.org/10.5716/WP17363.PDF

272. Agroforestry and Forestry in Sulawesi series: Landscape Management Strategies in Sulawesi: Review of Intervention Options. http://dx.doi.org/10.5716/WP17364.PDF

273. Household Food-Security and Nutritional Status of Women and Children in Buol Regency, Central Sulawesi, Indonesia. http://dx.doi.org/10.5716/WP17365.PDF

274. Palm oil expansion in tropical forest margins or sustainability of production? Focal issues of regulations and private standards. http://dx.doi.org/10.5716/WP17366.PDF

\section{8}

275. Decision analysis methods guide: Agricultural policy for nutrition http://dx.doi.org/10.5716/WP18001.PDF

276. Supporting human nutrition in Africa through the integration of new and orphan crops into food systems: Placing the work of the African Orphan Crops Consortium in context. http://dx.doi.org/10.5716/WP18003.PDF

277. Seri Pembangunan Ekonomi Pedesaan Indonesia. Pilihan Manajemen Budidaya Kacang Tanah sebagai Upaya untuk Memperbaiki Penghidupan Masyarakat Haharu. http://dx.doi.org/10.5716/WP18004.PDF

278. Estudio de línea de base CCAFS a nivel de hogar en Nicaragua y Costa Rica Fase de diagnóstico del estudio: "Contribución de la diversidad arbórea a los medios de vida para la adaptación y la mitigación al cambio climático http://dx.doi.org/10.5716/WP18005.PDF

279. Understanding tree cover transition, drivers and stakeholder perspectives for effective landscape governance. A case study in Na Nhan commune, Dien Bien province, Vietnam. http://dx.doi.org/10.5716/WP18006.PDF 
280. El Sistema "Quesungual": Agroforestería y manejo de suelos para la producción de maíz y frijol en laderas. http://dx.doi.org/10.5716/WP18007.PDF

281: Probabilistic Decision Modelling to Determine Impacts on Natural Resource Management and Livelihood Resilience in Marsabit County, Kenya. http://dx.doi.org/10.5716/WP18008.PDF

282. Shifting discourse, shifting power: how is climate change mitigation and justice negotiated in Indonesia? http://dx.doi.org/10.5716/WP18009.PDF

283. Result of Land Use Planning and Land Administration (LULA) Implementation in South Sumatra, East Kalimantan, Central Java and Papua http://dx.doi.org/10.5716/WP18010.PDF

284. Farmers' preferences for training topics and dissemination of agroforestry information in Indonesia. http://dx.doi.org/10.5716/WP18015.PDF

285. CSA-Diagnostic (CSA-Dx): A primer for investigating the 'climate-smartness' of ag technologies http://dx.doi.org/10.5716/WP18020.PDF

286. An analysis of the vulnerability of poor communities in Yunnan Province, China http://dx.doi.org/10.5716/WP18021.PDF

287. Gendered space and quality of life: gender study of out-migration and smallholding agroforestry communities in West Java Province, Indonesia.

http://dx.doi.org/10.5716/WP18024.PDF

288: Evaluation of UTZ certification coffee businesses in Guatemala, Honduras and Nicaragua. http://dx.doi.org/10.5716/WP18028.PDF

289. Agroforestry species of Peru: annotated list and contribution to prioritization for genetic conservation. http://dx.doi.org/10.5716/WP18029.PDF 
290. Indonesia Rural Economic Development Series.Growing plants on a barren hill: local knowledge as part of land restoration in Sumba Timur, Indonesia.

http://dx.doi.org/10.5716/WP18030.PDF

291. Assessing the Downstream Socioeconomic Impacts of Agroforestry in Kenya http://dx.doi.org/10.5716/WP18033.PDF

\section{9}

292: Los árboles fuera del bosque en la NAMA forestal de Colombia. Elementos conceptuales para su contabilización. http://dx.doi.org/10.5716/WP19002.PDF

293: Gender and Adaptation: An Analysis of Poverty and Vulnerability in Yunnan, China. DOI: http://dx.doi.org/10.5716/WP19004.PDF

294: Tree Cover on Agricultural Land in the Asia Pacific Region DOI: http://dx.doi.org/10.5716/WP19005.PDF

295: What do we really know about the impacts of improved grain legumes and dryland cereals? A critical review of 18 impact studies DOI: http://dx.doi.org/10.5716/WP19006.PDF

296: Breeders' views on the production of new and orphan crops in Africa: a survey of constraints and opportunities DOI: http://dx.doi.org/10.5716/WP19007.PDF

297: Biomass Resources in Rhino Camp and Imvepi Refugee Settlements and the Buffer Zone around these Settlements in West Nile, Uganda

DOI: http://dx.doi.org/10.5716/WP19031.PDF

298: Option for restocking woody biomass in refugee-hosting areas: Perspectives from communities in Rhino Camp and Imvepi Settlements, Uganda DOI: http://dx.doi.org/10.5716/WP19032.PDF 
299: Restoring ecosystems in refugee settlements using tree-based systems: The case of Rhino Camp and Imvepi Settlements in Uganda.

DOI: http://dx.doi.org/10.5716/WP19033.PDF

300: A theory-based evaluation of the Agroforestry Food Security Programme, Phase II in Malawi (AFSPII): Lessons for Scaling Up Complex Agronomic and Natural Resource Management Practices Developed and Tested in Research Settings.

DOl: http://dx.doi.org/10.5716/WP19036.PDF

301: Fuentes semilleras y especies agroforestales de los bosques secos tropicales del norte del Perú: estado actual y prioridades futuras. (Spanish) DOI: http://dx.doi.org/10.5716/WP19057.PDF

302: Seed sources and agroforestry species of tropical dry forests of northern Peru: current status and future priorities. (English)

DOl: http://dx.doi.org/10.5716/WP19058.PDF

303: Turmeric Production under Shade Management and Fertilization in Degraded Landscapes of Sumba Timur.

DOI: http://dx.doi.org/10.5716/WP19066.PDF

2020

304: From Tree Planting to Tree Growing: Rethinking Ecosystem Restoration Through Trees. DOl: http://dx.doi.org/10.5716/WP20001.PDF

305: Agroforestry species of Peru: Reference list and contribution to prioritization for the conservation of agroforestry genetic resources.

DOI: http://dx.doi.org/10.5716/WP20013.PDF

306: An exploratory analysis of cost-benefit analysis of landscape restoration.

DOI: http://dx.doi.org/10.5716/WP20014.PDF 
307: Wood fuel value chains in Kenya: a 20-year synthesis.

http://dx.doi.org/10.5716/WP20026.PDF

308: Especies agroforestales del Perú: Lista referencial y contribución a la priorización para la conservación de recursos genéticos agroforestales. Documento de Trabajo número 308.

Centro Internacional de Investigación Agroforestal

DOI: http://dx.doi.org/10.5716/WP20041.PDF

309: Simulasi Dampak Perubahan Tutupan Lahan dan Curah Hujan di DAS Citarum Hulu dengan Model GenRiver: Kalibrasi model dan analisa sensitivitas.

Authors: Lisa Tanika, Betha Lusiana dan Adis Hendriatna

DOI: http://dx.doi.org/10.5716/WP20048.PDF

310: Simulating the effect of change in land cover and rainfall in Upper Citarum Watershed:

calibration and sensitivity analysis of Genriver model

Authors: Lisa Tanika, Betha Lusiana dan Adis Hendriatna

DOI: http://dx.doi.org/10.5716/WP20049.PDF

311: Status of Perennial Tree Germplasm Resources in India and their Utilization in the Context of Global Genome Sequencing Efforts

DOI: http://dx.doi.org/10.5716/WP2020050.PDF 
World Agroforestry (ICRAF) is a centre of scientific and development excellence that harnesses the benefits of trees for people and the environment. Leveraging the world's largest repository of agroforestry science and information, we develop knowledge practices, from farmers' fields to the global sphere, to ensure food security and environmental sustainability.

ICRAF is the only institution that does globally significant agroforestry research in and for all of the developing tropics. Knowledge produced by ICRAF enables governments, development agencies and farmers to utilize the power of trees to make farming and livelihoods more environmentally, socially and economically sustainable at multiple scales.

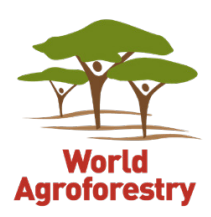

United Nations Avenue, Gigiri • PO Box 30677 • Nairobi, $00100 \cdot$ Kenya Telephone: +254207224000 or via USA +1 6508336645 Fax: +254207224001 or via USA +1 6508336646 Email: worldagroforestry@cgiar.org•www.worldagroforestry.org 